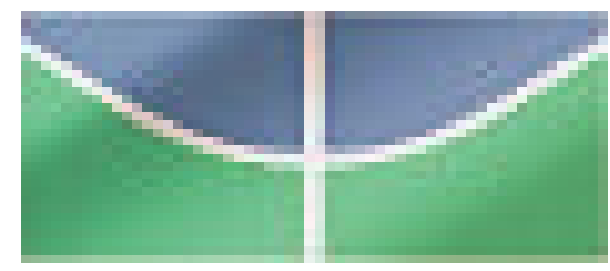

UNIVERSIDADE DE BRASÍLIA INSTITUTO DE CIÊNCIAS HUMANAS DEPARTAMENTO DE SERVIÇO SOCIAL

CONTROLE SOCIAL NA PROTEÇÃO DOS DIREITOS DA CRIANÇA E DO ADOLESCENTE.

TRABAHO DE CONCLUSÃO DE CURSO

Danielle Alves de Brito

Matrícula: 99/55381

Brasília - DF

Junho de 2007 


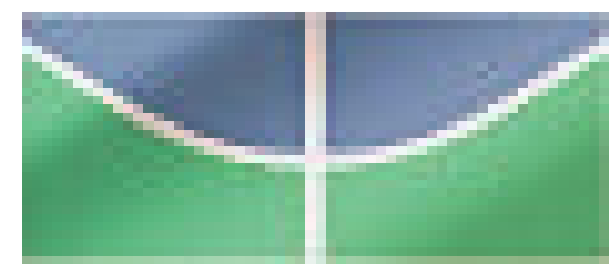

UNIVERSIDADE DE BRASÍLIA INSTITUTO DE CIÊNCIAS HUMANAS DEPARTAMENTO DE SERVIÇO SOCIAL

\section{CONTROLE SOCIAL NA PROTEÇÃO DOS DIREITOS DA CRIANÇA E DO ADOLESCENTE.}

Trabalho de Conclusão de Curso apresentado como requisito para a aquisição do grau de Assistente Social no curso de Serviço Social da Universidade de Brasília - UnB.

Orientadora: Maria Lúcia Pinto Leal 
CONTROLE SOCIAL NA PROTEÇÃO DOS DIREITOS DA CRIANÇA E DO ADOLESCENTE.

Trabalho defendido sob avaliação da Banca Examinadora constituída por:

Prof $^{a}$. Doutora Maria Lúcia Pinto Leal (Orientadora)

Prof. Doutor Mário Ângelo Silva

Universidade de Brasília - UnB

Prof $^{a}$. Mestre Ozanira Ferreira da Costa

Universidade de Brasília - UnB 


\section{AGRADECIMENTOS}

Gostaria de agradecer ao Conselho de Assistência Social do Distrito Federal - CAS/DF e ao Conselho dos Direitos da Criança e do Adolescente do Distrito Federal - CDCA/DF que possibilitaram os estudos de campo, fornecendo profissionais para a entrevista;

à Professora Doutora Maria Lúcia Pinto Leal, pelo conhecimento compartilhado, pelo direcionamento do trabalho, pela paciência e atenção que dedicou a este trabalho;

ao Professor José Airton de Brito, pelas sugestões e críticas apresentadas ao final deste estudo, bem como pelo seu apoio permanente; e

à Professora Fátima Fontenele, cujo apoio e dedicação sempre foram fundamentais, não só para a elaboração deste trabalho, mas durante todo o período de Graduação. 


\section{SUMÁRIO}

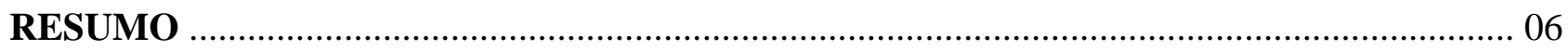

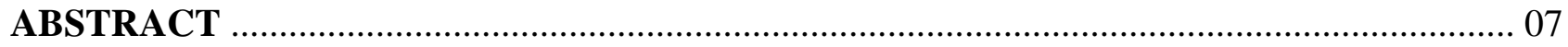

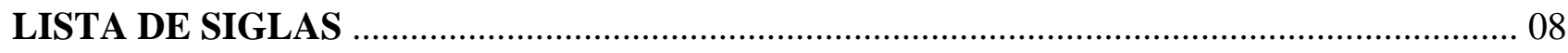

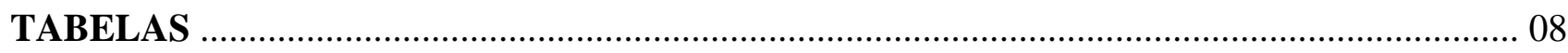

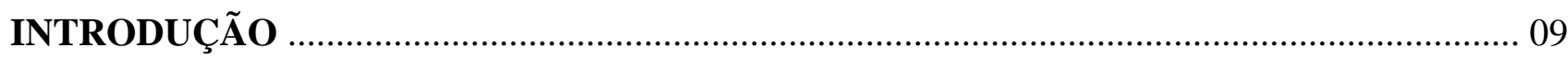

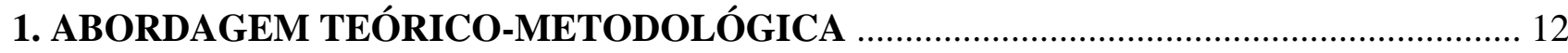

2. CONTROLE SOCIAL NA PROTEÇÃO DOS DIREITOS DA CRIANÇA E DO

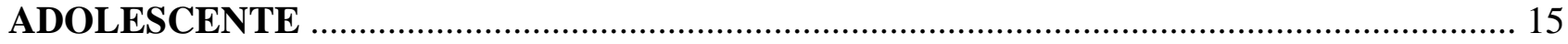

2.1. A Política de Assistência à Infância e Adolescência ..................................................... 15

2.1.1Processo Histórico da Política de Assistência à Infância no Brasil............................ 16

2.2. O Estado Democrático de Direito e a Proteção aos Direitos da Criança e do

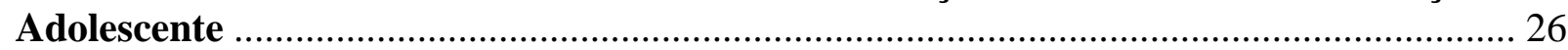

2.2.1. Os Conselhos de Direitos e o Controle Social ...................................................... 30

2.2.1.1. O Conselho de Assistência Social do Distrito Federal - CAS/DF ........... 32

2.2.1.2. O Conselho de Defesa da Criança e do Adolescente do Distrito Federal -

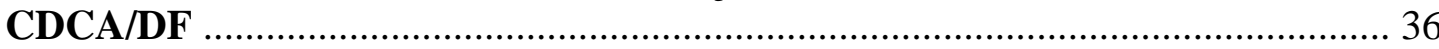

2.3. Articulação entre os Conselhos para a Proteção dos Direitos da Criança e do Adolescente

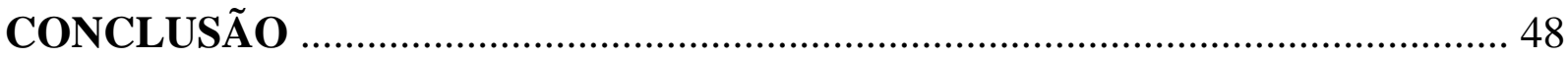

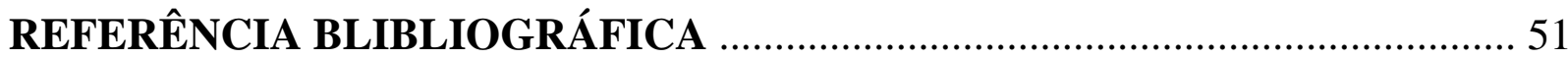

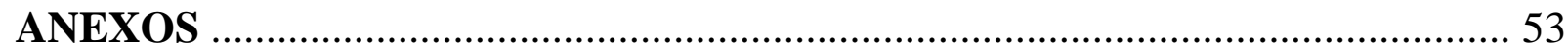




\section{RESUMO}

Esta pesquisa tem por objeto entender o grau de articulação entre o Conselho de Assistência Social do Distrito Federal - CAS/DF e o Conselho dos Direitos da Criança e do Adolescente do Distrito Federal - CDCA/DF, no acompanhamento, controle e fiscalização da Política de Proteção aos Direitos da Criança e do Adolescente no Distrito Federal. A hipótese da pesquisa é de que o Conselho de Assistência Social - CAS/DF e o Conselho de Direitos da Criança e do Adolescente - CDCA/DF não se articulam e isto fragiliza a Política de Proteção aos Direitos da Criança e do Adolescente. O objetivo geral da pesquisa é encontrar uma justificativa política e teórica para a necessidade de articulação entre os Conselhos de Direitos que acompanham, fiscalizam e controlam a Política de Proteção aos Direitos da Criança e do Adolescente visando o aperfeiçoamento dos mecanismos de controle social. A partir da Constituição de 1988 foi instituída a possibilidade de participação popular na gestão das políticas pública. O controle social é um mecanismo democrático de participação popular na formulação, execução e avaliação das políticas sociais. Dentre as formas de execução do controle social destaca-se a atuação dos Conselhos de Direitos. Os Conselhos de Direito são órgãos integrantes do sistema descentralizado com competência normativa, deliberativa e fiscalizadora das políticas públicas. No Distrito Federal a Política de Proteção aos Direitos da Criança e do Adolescente é executada de forma fragmentada e setorizada pela Secretaria de Justiça e de Direitos Humanos e pela Secretaria de Ação Social. O controle social exercido pelo Conselho de Assistência Social do Distrito Federal - CAS/DF e pelo Conselho dos Direitos da Criança e do Adolescente - CDCA/DF também é fragmentado, o que reforça a fragilidade das Políticas Sociais. Defende-se que os Conselhos de Direito devem assumir a responsabilidade promover o debate intersetorial da política de proteção aos diretos da criança e do adolescente de forma a manter a interação e a construção de uma agenda comum entre estes órgãos.

Palavras-chave: Direitos da Criança e do Adolescente. Estado Democrático de Direitos. Sistema Descentralizado. Participação Social. Democracia Direta. Controle Social. Conselhos de Direitos. 


\begin{abstract}
ASBSTRACT
The objective of this research is understand the rate of articulation among the Counsel of Aid Social of the District Federal and the Counsel from the Rights from Child and of the Adolescent of the District Federal, into the accompanying, control and inspection from Policy of Protection to the Rights from Child and of the Adolescent into the District Federal. The assumption from research is of what the Counsel of Aid Social and the Counsel of Rights from Child and of the Adolescent haven't you articulate and this brittleness the policy of Protection to the Rights from Child and of the Adolescent. The purpose across the board from research is meet only one justification policy and abstract for necessity of articulation among the Admonitions of Rights what accompanying, be subject to fiscal controls and control the policy of Protection to the Rights from Child and of the Adolescent aim at the enhancement from the mechanisms of control social. The part from Constitution of 1988 was established the possibility of participation popular on administration from the public policies. The screening social that's a mechanism democratic of participation popular on formulation, execution and assessment from the policies sociais. In the midst of the shapes of execution of the control social highlighted - if the multi-skilled from the Admonitions of Rights. The counsels of Right are agencies integrates of the system uncentered with ability normative, deliberative and inspection from the public policies. Into the District Federal the policy of Protection to the Rights from Child and of the Adolescent is carried out of she forms fragmented \& setorizada by Secretariat of Justice and of Human rights and by Secretariat of Act Social. The screening social exercise at Admonition of Aid Social of the District Federal and at Admonition from the Rights from Child \& of the Adolescent it is also fragmented, the one to reinforced the frailty from the Policies Socials. Defends - if as the Admonitions of Right owes assume the responsibility promote the talk intersetorial from policy of protection to the rights from child and of the adolescent of she forms the maintain the interaction and the construction from a agenda common among these organs.
\end{abstract}

Key Words: Rights from the Child and from the Juvenile. State Democratic as of Rights. System Federative and Uncentered. Participation Social. Democracy. Controls Social. Advice as of Rights. 


\section{LISTA DE SIGLAS}

CAS/DF - Conselho de Assistência Social do Distrito Federal

CDCA/DF - Conselho dos Direitos da Criança e do Adolescente

CNAS - Conselho Nacional de Assistência Social

CONANDA - Conselho Nacional de Direitos da Criança e do Adolescente

ECA - Estatuto da Criança e do Adolescente

FEBEM - Fundação Estadual de Bem-Estar do Menor

FUNABEM - Fundação Nacional de Bem-Estar

LBA - Legião Brasileira de Assistência

LOAS - Lei Orgânica da Assistência Social

MNMMR - Movimento Nacional de Meninos e Meninas de Rua

ONG - Organização Não-Governamental

PNBEM - Política Nacional do Bem-Estar do Menor

SAM - Serviço de Assistência a Menores

SEAS - Secretaria de Assistência Social do Distrito Federal

SUAS - Sistema Único da Assistência Social

UNICEF - Fundo das Nações Unidas para a Infância

\section{TABELAS}

Tabela 1. Como se dá a execução e o controle social da Política de Proteção aos Direitos da Criança e do Adolescente. 


\section{INTRODUÇÃO}

A Constituição de 1988 instituiu uma nova ordem jurídica, política e social, o que implicou na democratização do Estado e na possibilidade de participação da sociedade na gestão pública, por meio da sociedade civil organizada, dos Fóruns, das Conferências e dos Conselhos de Direitos. Dentre estas instâncias de participação popular chama atenção para a atuação dos Conselhos de Direitos no controle social.

O controle social é um mecanismo democrático de participação da sociedade civil na gestão e organização das entidades públicas e privadas. Esta participação é exercida de forma muito peculiar pelos Conselhos de Direito, que são órgãos integrantes do sistema descentralizado com competência normativa, deliberativa e fiscalizadora das políticas públicas.

Os Conselhos de Direitos atuam como mecanismos que possibilitam a democracia direta, tendo sido criados em meados da década de 90. Apesar de recentes estes órgãos desempenham um papel fundamental porque atuam na formulação, no acompanhamento e na avaliação de prioridades para as políticas sociais.

A pesquisa surgiu durante a realização de estágio no Conselho de Assistência Social do Distrito Federal - CAS/DF, durante o ano de 2006. Neste campo tive oportunidade de observar a transversalidade da Política de Assistência Social, que contém diversos programas voltados para a criança e para o adolescente, como por exemplo, o benefício de prestação continuada, atividades complementares, abrigamento e o Programa de Erradicação do Trabalho Infantil - PETI, dentre outros.

Assim como a Política de Assistência Social o controle social também segue esta característica de transversalidade, sendo o Conselho de Assistência Social do Distrito Federal CAS/DF responsável por normatizar, acompanhar e fiscalizar esta Política, que abrange o tema criança e adolescente. Contudo, não mantém qualquer relação com o Conselho dos Direitos da Criança e do Adolescente do Distrito Federal - CDCA/DF. 
Esta falta de articulação entre os Conselhos de Direito traz prejuízos para a Política de Proteção à Criança e ao Adolescente, na medida em que atuam de forma segmentada e individualizada diante do tema criança e adolescente, e seguem a lógica da fragmentação e da setorização das políticas sociais.

Neste sentido pode-se afirmar que a falta de articulação entre o Conselho de Assistência Social do Distrito Federal - CAS/DF e o Conselho dos Direitos da Criança e do Adolescente - CDCA/DF reforça a fragilidade da Política de Proteção aos Direitos da Criança e do Adolescente, que deveria ser entendida como um todo harmônico e interelacionado.

Diante desta realidade a discussão acerca do controle social na proteção dos direitos da criança e do adolescente se torna fundamental para o fortalecimento da política social.

A Abordagem teórica metodológica adotada foi de primeiro conhecer a natureza e função da Política de Proteção aos Direitos da Criança e do Adolescente, do Estado Democrático de Direito, do Controle Social e dos Conselhos de Direitos. Entendendo que os Conselhos de Direitos não mantém ações interelacionadas para a proteção dos direitos da criança e do adolescente, buscando o aperfeiçoamento do controle social. Foi utilizado o método dialético onde se visa aperfeiçoar o controle social, levando em conta a falta de articulação entre os Conselhos de Direitos, a fragmentação das Políticas Sociais e a fragilidade da participação da sociedade civil. Tendo sido esta pesquisa dividida em quatro partes.

A primeira parte diz respeito à Política de Assistência à Infância e Adolescência, onde foi abordado o processo histórico da assistência à infância no Brasil, que se dividiu em três momentos: o primeiro se caracterizou pelo predomínio da caridade; o segundo pela consolidação do sistema jurídico-administrativo; e terceiro pelo reconhecimento da criança e do adolescente como sujeito de direitos.

A segunda parte trata do Estado Democrático de Direito e da Proteção aos Direitos da Criança e do Adolescente, mencionando o Sistema de Garantias previsto no Estatuto da Criança e do Adolescente - ECA; a possibilidade de participação social no processo de gestão pública; e a concepção de controle social advinda da Constituição de 1988. 
A terceira parte versa sobre os Conselhos de Direitos e o controle social visando compreender a concepção dos Conselhos de Direitos e a atuação comum do Conselho de Assistência Social do Distrito Federal - CAS/DF e o Conselho dos Direitos da Criança e do Adolescente CDCA/DF na Política de Proteção aos Direitos da Criança e do Adolescente do Distrito Federal.

Por fim a quarta parte menciona a necessidade de articulação entre os Conselhos de Direitos para a Proteção dos Direitos da Criança e do Adolescente, tendo em vista que os Conselhos são canais de participação que precisam ser fortalecidos por meio de ações conjuntas e sistemáticas garantindo a universalização dos direitos e quebrando a lógica de fragmentação das políticas sociais.

Deste modo pretende-se de forma abrangente compreender a sistemática da Política de Proteção aos Direitos da Criança e do Adolescente e do Estado Democrático de Direito para poder analisar a importância dos Conselhos de Direitos no controle social e a necessidade de articulação entre estes órgãos para a proteção integral da criança e do adolescente. 


\section{ABORDAGEM TEÓRICO-METODOLÓGICA}

O objeto da pesquisa é entender o grau de articulação entre o Conselho de Assistência Social do Distrito Federal - CAS/DF e o Conselho dos Direitos da Criança e do Adolescente do Distrito Federal - CDCA/DF, no acompanhamento, controle e fiscalização da Política de Proteção aos Direitos da Criança e do Adolescente no Distrito Federal.

A pesquisa parte da hipótese de que o CAS/DF e o CDCA/DF ainda não se articulam e isto fragiliza a Política de Proteção aos Direitos da Criança e do Adolescente.

O Estado Democrático de Direito instituído pela Constituição de 1988, é aquele cujo direito imantado deve conter valores democráticos, de acordo com o interesse coletivo. $\mathrm{O}$ sistema federativo permite a descentralização das decisões e a repartição de poderes e responsabilidades entre as três esferas de governo.

A democratização do Estado implicou no processo de participação da sociedade na gestão pública, principalmente, com a implementação de Conselhos paritários. Os Conselhos são os órgãos integrantes do sistema descentralizado, de competência normativa, deliberativa e fiscalizadora das políticas sociais, que exercem o controle social. O controle social consiste na participação da sociedade civil, na gestão e organização das entidades publica e privadas.

Atuando na defesa e na proteção dos direitos das crianças e adolescentes do Distrito Federal está o Conselho da Assistência Social do Distrito Federal - CAS/DF e o Conselho dos Direitos da Criança e do Adolescente do Distrito Federal - CDCA/DF.

No Distrito Federal a Política de Proteção aos Direitos da Criança e do Adolescente, bem como seu controle social obedecem à lógica da setorização e da fragmentação, em que estes são tidos como partes separadas, sem comunicação e articulação. Portanto, os Conselhos de Direitos devem promover a discussão da Política de Proteção aos Direitos da Criança e do Adolescente nos espaços públicos, criando veículos de informação integrada entre os vários Conselhos. Neste sentido a articulação entre estes órgãos será um instrumento estratégico para quebrar a lógica fragmentada das Políticas Sociais. 
O objetivo geral desta pesquisa é encontrar uma justificativa política e teórica para a necessidade de articulação entre os Conselhos de Direitos que acompanham, fiscalizam e controlam a Política de Proteção aos Direitos da Criança e do Adolescente visando o aperfeiçoamento dos mecanismos de controle social.

Os objetivos específicos da pesquisa são compreender a Política de Proteção aos Direitos da Criança e do Adolescente, por meio de uma análise comparativa da legislação e do processo histórico da criança e do adolescente; entender como são executadas atualmente as ações de proteção à criança e ao adolescente e em que lógica estão inseridas; analisar a natureza, composição e função dos Conselhos de Direitos; e buscar justificativa teórica política e teórica para a necessidade da articulação entre os Conselhos de Direitos no aperfeiçoamento do controle social.

O método de abordagem utilizado será o dedutivo, que parte de uma idéia geral para a particular, entendendo primeiramente a natureza dos Conselhos de Direitos, do controle social e da Política de Proteção aos Direitos da Criança e do Adolescente para posteriormente analisar a execução desta política e a necessidade de articulação entre os Conselhos de Direitos. Será também utilizado o método empírico-dedutivo que visará responder qual o grau de articulação entre os Conselhos de Direitos e qual a real necessidade desta articulação.

Utilizará ainda o método dialético, onde se procura a análise do problema diante das suas diversas formas, partiremos da análise da atuação dos Conselhos de Direitos para verificar que a articulação destes dois órgãos é importante para a proteção da criança e do adolescente.

Quanto ao método de procedimentos este será o histórico, que estuda a natureza dos institutos e para que foram criados; o comparativo, onde será analisado a competência de cada Conselho de Direito e sua atuação na defesa dos direitos da criança e do adolescente.

As fontes de pesquisa utilizadas foram a doutrina jurídica, artigos literários diversificados que abordaram os diversos aspectos do tema, entrevista, observação e a análise documental. 
As entrevistas foram realizadas em 2007, valendo destacar ainda que, no ano de 2007 assumiu um novo Governo no Distrito Federal, e pode ter ocorrido algumas mudanças organizacionais na estrutura dos Conselhos de Direitos.

A entrevista no Conselho de Assistência Social do Distrito Federal - CAS/DF foi realizada em janeiro de 2007, com a assistente social Socorro Garcia Lopes. A entrevista no Conselho dos Direitos da Criança e do Adolescente do Distrito Federal - CDCA/DF foi realizada em abril de 2007, com a assessora Meire Freitas de Moraes.

A observação de campo foi possível durante todo o ano de 2006, em razão da realização de estágio no Conselho de Assistência Social do Distrito Federal - CAS/DF, onde foi elaborada uma Análise Institucional e um Projeto de Intervenção. Quanto ao Conselho dos Direitos da Criança e do Adolescente do Distrito Federal - CDCA/DF a observação somente pode ser realizada durante a entrevista, onde estive atenta às reações de cada pergunta. Mas como o objeto deste trabalho é a necessidade de articulação entre os Conselhos de Direitos, acredito que a observação de campo realizada no CAS/DF foi suficiente.

Também foram analisadas as Leis de criação destes Conselhos de Direitos, Regimentos Internos, Lei Orgânica da Assistência Social - LOAS, Estatuto da Criança e do Adolescente - ECA, Regulamentos do CONANDA e do CNAS, dentre outros documentos disponibilizados pelo CAS/DF e pelo CDCA/DF. 


\title{
2. CONTROLE SOCIAL NA PROTEÇÃO DOS DIREITOS DA CRIANÇA E DO ADOLESCENTE
}

\begin{abstract}
A Constituição Federal de 1988 foi instituída em um período de redemocratização do país e como tal significou uma grande mudança política, social e ideológica. Esta norma permitiu a ampliação dos espaços de atuação da sociedade civil, como a possibilidade da criação de Conselhos de Direitos, que seriam órgãos do sistema descentralizado e participativo, objetivando o controle social nas políticas públicas.
\end{abstract}

O controle social é um mecanismo da democracia direta que permite a participação da sociedade civil na formulação e avaliação das políticas públicas. Além da Sociedade Civil organizada, os Fóruns, Conferências e Comitês, os Conselhos de Direitos também exercem o controle social das políticas públicas. Em razão do processo de fragmentação e de setorização das políticas sociais há diversos Conselhos de Direitos para cada área da política social.

Este trabalho tratará da Política de Proteção aos Direitos da Criança e do Adolescente no Distrito Federal, e de seu controle social, no tocante à atuação do Conselho de Assistência Social do Distrito Federal - CAS/DF e do Conselho dos Direitos da Criança e do Adolescente - CDCA/DF, daí a necessidade de articulação entre estes dois órgãos para que esta Política seja melhor efetivada.

Mas, antes de tratar especificamente deste tema, faz-se necessário comentar a Política de Proteção à Infância e Adolescência.

\subsection{A Política de Assistência à Infância e Adolescência}

A Política de Proteção aos direitos da criança e do adolescente mantém estreito relacionamento com as políticas sociais, especialmente com a Política de Assistência Social. Portanto, para entender melhor a política de assistência à criança e ao adolescente faz-se necessário conhecer seu processo histórico. 


\subsubsection{Processo Histórico da Política de Assistência à Infância no Brasil}

A análise histórica da infância passa pela análise de instituições, sejam elas a família, escola, fábrica, creches, abrigos, centros de internação, dentre outros. A família, como é conhecida hoje, surgiu na Idade Média, se consolidando na ordem capitalista. Mas esta instituição sempre existiu, sendo o primeiro núcleo social com o qual o homem toma contato.

Os laços familiares entre os pais e as crianças neste período não eram eternos, só permaneciam enquanto houvesse a necessidade da sobrevivência, superado este período os filhos saiam desta relação e os pais não tinham mais a obrigação da relação. ${ }^{1}$

Ainda na antiguidade os babilônicos seguiam os dispositivos do Código de Hamurabi, onde o tratamento dado às crianças era rígido se elas infringissem a lei, mas pouco se sabe das relações familiares desta sociedade.

Na família romana o vínculo existente nas relações familiares era pela submissão à pátria potestas, que era uma espécie de chefe e detinha o poder de punir e responsabilizar os membros por atos ilícitos. Neste período a criança era conferida o status de coisa, pois eram tratados como propriedade dos pais.

Com os germanos nos fins do Século V d.C., no entanto, a estrutura familiar foi transformada e, na Idade Média um novo tipo de relação familiar se formou, onde os próprios filhos enquanto crianças, foram os agentes de toda a transformação. Neste sentido vale citar a autora Daniele Comim Martins:

"Durante muito tempo a criança não era tida como importante dentro da "família" medieval. Eram freqüentes as mortes de crianças, que criavam uma indiferença dos pais em relação ao fato. $\mathrm{O}$ tratamento dispensado às crianças era mais semelhante ao dado a um animalzinho doméstico do que ao dado a uma pessoa somente

\footnotetext{
${ }^{1}$ Mas ainda ocorriam famílias que mantinham os laços familiares unidos, contudo a permanência na família decorria da vontade de seus membros e não dos fenômenos naturais.
} 
quando o adolescente se tornava de fato adulto é que ele passava a assumir um papel dentro da família."2

As transformações sobre a família iniciaram nos fins da Idade Média, mas foi a redefinição da cidade, como urbe capitalista, que a família definiu seu caráter privado. Segundo Áries a família moderna restringe aos pais e filhos e passou a ter uma identidade e a ser responsabilizada pelo sucesso ou fracasso futuro de suas crianças. ${ }^{3}$

O período colonial no Brasil foi marcado pelo pouco desenvolvimento urbano. $\mathrm{O}$ final do século XVIII e início do século XIX foram marcados pela Independência do Brasil. Assim até o início do século XX, as iniciativas de atendimento à infância pobre, em sua maioria, ficaram a cargo de ações de caráter familiar e particular e religioso.

Mesmo o atendimento à criança pobre tendo características privadas e religiosas as Casas de Expostos, conhecidas como Casas da Roda ${ }^{4}$ eram uma forma típica de atendimento nos séculos XVIII e XIX, que tinham como propósito maior a proteção aos padrões de moral pública e familiar da época. Acolhiam, no anonimato, filhos de "mães solteiras", de "mulheres de má conduta", crianças abandonadas pelos pais devido à extrema pobreza, filhos de escravos, entre outros enjeitados. ${ }^{5}$ A Roda somente é desativada em 1938, quando a criança pobre deixa de ser objeto apenas da "caridade" e passa a ser objeto de políticas do Estado.

Segundo Rizzini nesta época o Estado se preocupava com a assistência à infância sob a égide dos ideais higienistas e afirma que "muitas rodas de expostos surgiram no Brasil, quando

\footnotetext{
${ }^{2}$ MARTINS, Danielle Comim. Estatuto da Criança e do Adolescente e a Política de Atendimento. 1. ed. Curitiba: Juruá, 2004.

3 Apud MARTINS, Danielle Comim. Estatuto da Criança e do Adolescente e a Política de Atendimento. 1. ed. Curitiba: Juruá, 2004.

${ }^{4}$ A Roda era um dispositivo aberto do lado da rua ligado à instituição religiosa, onde se colocavam crianças recémnascidas e enjeitadas e que girava para dentro da casa, onde a criança era recolhida, cuidada e educada sem o mínimo risco de identificação.

${ }^{5}$ DIDONET, Vital. Representação da Criança na Sociedade Brasileira. Infância e Desenvolvimento: Desafios e Propostas, Organizadores Antônio Rocha Magalhães e Walter Garcia, Brasília: IPEA, Série IPEA; n.140, 1993.
} 
a Europa estava sendo combatida pelos higienistas e reformadores, pela alta mortalidade e pela suspeita de fomentar o abandono de crianças". 6

No início do século XIX fatores como a imigração, a abolição da escravatura, a construção de ferrovias, melhoramentos urbanos e o início da industrialização trazem transformações na estrutura econômica e social do país. Neste momento uma ordem urbanística foi criada, modificando o espaço familiar, onde a "arquitetura e o isolamento fez parte da redefinição do espaço público e privado" 7 , com o modelo burguês de habitação. Momento este exposto pela autora Daniele Comim na seguinte passagem de sua obra:

"Nessa reestruturação da ordem urbana, diferentemente do que ocorreu na Europa no início da Idade Média, quando a família se recolheu espontaneamente em suas casas, dando origem a nossa "família" tal como a conhecemos, a família brasileira foi arrancada do meio público em que vivia e se socializava e foi abandonada e sim mesma, substituindo por si própria as funções que eram assumidas na rua pela sociedade então."8

Com o desenvolvimento urbano e a criação do Estado Nacional Brasileiro, o atendimento médico à família começou a ser difundido em todas as classes sociais "como mecanismo regulador e de controle, capaz de estimular, incentivar ou criar sentimentos na população até então inexistentes ou imperceptíveis, adaptando os indivíduos à ordem do poder". 9 A utilização da prática médica e assistencial utilizada neste período como mecanismo de controle social foram denominadas de Propostas Higienistas.

Em razão da ampliação do controle médico sobre a criação dos filhos das famílias pobres, as propostas higienistas assumiram "diversos tons retóricos, ora assistencialistas, ora sanitaristas, ora medidos, ora morais, prescrevendo regras de conduta pessoal e social" vigiando,

${ }^{6}$ RIZZINI, Irene; RIZZINI, Irmã. A Institucionalização de Crianças no Brasil: percurso histórico e desafios do presente. Editora PUC, Rio de Janeiro: 2002.

${ }^{7}$ MARTINS, Danielle Comim. Estatuto da Criança e do Adolescente e a Política de Atendimento. 1. ed. Curitiba: Juruá, 2004

${ }^{8}$ Ibidem.

${ }^{9}$ Ibidem. 
inclusive, pelo seu cumprimento. ${ }^{10}$ Segundo Franco Vaz a ideologia higienista tem características partenalistas, defendendo a intervenção mínima do Estado diante do problema da criança desvalida. $^{11}$

Neste período o espaço da família é redefinido pela nova ordem, também a criança e o jovem passam a ocupar novos espaços, além da família, como a escola onde seriam reproduzidas relações sociais existentes no espaço público. A partir da iniciativa e da pressão dos higienistas, foram sendo constituídas desde o Império articulações entre público e privado, culminando na fundação de obras filantrópicas.

É a partir do século XX que as iniciativas do Estado de proteção ao menor ganham relevância e são fundamentais para a edição do Código de Menores em 1927, que foi encarregada de enfrentar tanto a problemática dos atos antijurídicos realizados por crianças, como a derivada do abandono e da desproteção familiar, situações qualificadas como "irregulares".

O Código de Menores, estabelecido pelo Decreto n $17.943-\mathrm{A}$, de 12 de outubro de 1927, consolida as leis de assistência de proteção a menores, especialmente focalizada nos delinqüentes e abandonados. Sendo as políticas para a infância voltada para aqueles que estavam sem família, considerados coitadinhos e para os que ameaçavam a ordem pública.

Por sua vez, o Estado, sob o ideais das propostas higienistas, intervinha junto á criança para estabelecer a vigilância da autoridade pública, sobrepondo-se à família para garantir a higiene e a raça, por meio do Programa de Controle de Lactação e da Alimentação para inspeção das pessoas que tivessem crianças pequenas sob sua guarda, podendo a autoridade pública impedir o abrigo em casas consideradas perigosas, anti-higiênicas ou imorais. ${ }^{12}$

${ }^{10}$ VIEIRA, L.M.F. Mal Necessário: Creches no Departamento Nacional da Criança. Caderno de Pesquisa, n.67, p. 3-16, nov. 1988.

${ }^{11}$ Apud. INSTITUTO INTERAMERICANO DEL NIÑO. A Arte de Governar Crianças: A História das Políticas Sociais, da Legislação e da Assistência à Infância no Brasil. Rio de Janeiro: Editora Universitária Santa Úrsula, AMAIS Livraria e Editora, 1995.

${ }^{12}$ FALEIROS. Vicente de Paulo. Uma Década de Direitos: Avaliação dos dez anos de Estatuto da Criança e do Adolescente. Série Escola de Conselhos. Cadernos para a Cidadania. Brasília: CECRIA, 2000. 
O Código de Menores trouxe as seguintes classificações à criança: os abandonados que não tinham habitação certa, nem responsáveis, com famílias consideradas imorais, ou abusivas pela crueldade, negligência ou exploração e que tivessem situações de perigo. Os vadios eram os rebeldes que vivem na casa dos pais, tutor, ou guarda, porém, eram encontrados habitualmente a vagar pelas ruas e logradouros públicos. Os mendigos eram os que habitualmente pediam esmolas. Os libertinos eram aqueles que praticavam atos obscenos, prostitutos ou que viviam da prostituição de outro. ${ }^{13}$

A referente legislação caracterizou-se principalmente pelo controle da infância abandonada e delinqüente, por meio da garantia da ordem moral; manteve a visão higienista e repressora; facilitou a inserção da criança no trabalho; previu a utilização do abrigamento e o internamento como forma de correção; a criança era vista como incapaz e perversa; o poder absoluto era do Estado sobre a família e a criança; a implementação do menorismo como garantia de medidas especiais para os menores de 18 anos; e o estimulo ao trabalho e combate ao vício como forma de reabilitação. $^{14}$

Pode-se afirmar que esta representou um avanço à medida que dava à criança a possibilidade de ser objeto de políticas públicas, ao invés da caridade; aboliu o Sistema de Rodas, mas manteve o princípio de preservar o sigilo sobre a origem da criança.

Como havia possibilidade de trabalho para as crianças no Código de Menores a relação que as crianças tinham com o trabalho era de exploração, uma vez que a mão de obra infantil é usada de forma abundante na indústria e o salário das crianças e adolescentes representa um complemento para os baixos rendimentos das famílias operárias. ${ }^{15}$

A indústria de tecelagem se interessava bastante pelo trabalho infantil sob o argumento de que a "finura dos dedos das crianças" se adapta melhor ao maquinismo, que é também

${ }^{13}$ DECRETO n ${ }^{\text {17.943-A, de }} 12$ de outubro de 1927. Dispõe sobre o Código de Menores.

${ }^{14}$ Ibidem.

${ }^{15}$ Segundo o livro Lugares da Infância "a mecanização foi uma forma de estabelecer controle sobre os trabalhadores à medida que ela possibilitava, fundamentalmente, duas coisas: a redução do número de empregados e, sobre tudo a substituição dos trabalhadores especializados pela mão-de-obra muito barata, dócil e abundante dos migrantes expulsos do campo, das mulheres que a miséria das famílias operárias empurrava para os empregos e, finalmente, das crianças que podiam ser compradas ou alugadas nos asilos para os pobres". 
mencionada por Marx: "procurava principalmente dedos pequenos e ágeis". ${ }^{16} \mathrm{Na}$ verdade o interesse da indústria pelo trabalho infantil não era somente pelas "finuras dos dedos" mas pela possibilidade de baixar gastos com mão-de-obra e aumentar a jornada de trabalho. Também a situação de miséria em que viviam muitos camponeses contribui para a colocação de crianças no mundo do trabalho. ${ }^{17}$ Vale citar a passagem da obra Lugares da Infância:

“Temos, então, que as fábricas só obtiveram sua viabilidade às custas da escravidão infantil. Não é um passado que recomende boas esperanças futuras. Mas a fábrica não surgiu para multiplicar a produção ou reduzir custos. Se advento marcou uma tentativa de utilização do trabalho cativo em lugares fechados, onde o comando do empregador poderia ficar mais distante de qualquer resistência dos que trabalhavam. A fábrica, assim como a prisão, foi resultado de uma ação política e não tecnológica. Ela criou as condições para o cativeiro de empregados que podiam ser explorados ininterruptamente, ao sabor das possibilidades mecânicas que os recursos hidráulicos e do vapor permitiam. A fábrica é a exploração de todos os recursos, entre eles o homem, levada ao limite em que tudo pode ser totalmente exaurido e transformado em mercadorias lucrativas e dejetos imprestáveis. E como os recursos humanos podiam ser comprados a baixo custo nas workhouses dos pobres, os infelizes com os quais os industriais supriam suas máquinas foram sempre utilizados até o esgotamento total". ${ }^{18}$

Nos anos 30 Getúlio Vargas, cujo governo se caracteriza por um projeto centralizador e intervencionista, institui o Ministério do Trabalho, com o objetivo de intervir na questão social, o amparo e a defesa do proletariado urbano e rural. Este Ministério adota uma política corporativista de harmonização das classes sociais, por meio de regulação do Estado tanto pela Justiça do Trabalho como pelo sindicalismo tutelado, sendo este mais um instrumento assistencial do que reivindicativo. ${ }^{19}$

${ }^{16}$ Apud. FALEIROS. Vicente de Paulo. Uma Década de Direitos: Avaliação dos dez anos de Estatuto da Criança e do Adolescente. Série Escola de Conselhos. Cadernos para a Cidadania. Brasília: CECRIA, 2000.

${ }^{17}$ Neste período não só a indústria defende a presença de crianças pobres no trabalho, mas o Estado também criam Escolas de Aprendizes justificadas pelo desenvolvimento urbano das cidades e pelo discurso de preparar tecnicamente para o trabalho filhos de desfavorecidos.

${ }^{18}$ MERISSE, Antônio; JUSTO, José Sterza; ROCHA, Carlos. et al. Lugares da Infância: reflexões sobre a história da criança na fábrica, creche e orfanato. São Paulo: Arte e Ciência, 1997.

${ }^{19}$ INSTITUTO INTERAMERICADO DEL NIÑO. A Arte de Governar Crianças: A História das Políticas Sociais, da Legislação e da Assistência à Infância no Brasil. Rio de Janeiro: Editora Universitária Santa Úrsula, AMAIS Livraria e Editora, 1995. 
Em 1940, o Decreto-Lei 2.204 prevê diretrizes de proteção à maternidade, à infância e à adolescência e cria o Departamento Nacional da Criança com o objetivo de coordenar todas as atividades dirigidas à infância. ${ }^{20}$ Em 1941 o Decreto Lei $n^{\circ} 3.799$ funda o Serviço de Assistência a Menores (SAM), com atribuição de prestar, em todo o território nacional, amparo social a menores desvalidos e infratores. ${ }^{21}$

Em 1942, surge no cenário nacional a Legião Brasileira de Assistência (LBA), com o objetivo de apoiar as famílias dos soldados que integravam a Força Expedicionária brasileira. "Sua entrada no cenário histórico se dá como a expressão institucional do quadro sócio-político da época, profundamente vinculado aos interesses governamentais, principalmente como instrumento de controle da emergente questão social". ${ }^{22}$

Desde a década de 1950, autoridades públicas, que coordenavam o SAM, propuseram um novo instrumento que culminou no surgimento da Fundação Nacional de Bem-Estar FUNABEM, em 1964. A FUNABEM foi instalada no primeiro ano da ditadura militar, e tinha por objetivo instituir o "anti-SAM", com diretrizes que opunham àquelas criticadas no SAM. Segundo Rizzini:

“As propostas que surgem para a instauração de um novo órgão nacional centramse na autonomia financeira e administrativa da instituição e na rejeição ao 'depósito de menores', nos quais se transformaram os internatos para crianças e adolescentes das camadas populares." 23

A Política Nacional do Bem-Estar do Menor - PNBEM, cujas diretrizes foram propostas pelo Governo de Castelo Branco, foi um instrumento de normatização, mas não tinha como objetivo o reconhecimento de direitos, e sim de planejamento e coordenação da ação

\footnotetext{
${ }^{20}$ A ação do Departamento foi marcante ao longo de décadas seguintes, e ainda está viva a influência de suas "normas" e "preceitos", por meio de publicações de intenso conteúdo médico-sanitarista e de cunho moralizante, sua ação transcende a questão da diminuição da mortalidade infantil.

${ }^{21}$ O SAM teve uma trajetória ineficaz, sua atuação teve caráter policial-punitivo e altamente corrupta, passando assim a suscitar uma reação pública de protesto, sendo decretado sua falência em 1954. Salienta-se ainda que a atuação do Estado em articulação com o setor privado é intensificada, sendo criadas várias instituições e obras sociais.

22 DIDONET, Vital. Representação da Criança na Sociedade Brasileira. Infância e Desenvolvimento: Desafios e Propostas, Organizadores Antônio Rocha Magalhães e Walter Garcia, Brasília: IPEA, Série IPEA; n.140, 1993.

${ }^{23}$ RIZZINI, Irene RIZZINI, Irmã. A Institucionalização de Crianças no Brasil: percurso histórico e desafios do presente. Editora PUC, Rio de Janeiro: 2002.
} 
assistencial à infância. Como uma das estratégias de implementação desta política o Governo Federal estimulava a criação de Fundações Estaduais de Bem-Estar do Menor (FEBEMs).

O período pós-64 introduziu alterações significativas nos padrões de proteção social, pois é neste momento que o Estado implementa algumas políticas sociais. Neste sentido vale mencionar Draibe:

"É esse o momento em que efetivamente se organiza os sistemas nacionais públicos ou estatalmente regulados (saúde, educação, assistência social, previdência, e habitação), abrindo espaço para implementação de políticas de massa, de relativamente ampla cobertura". ${ }^{24}$

A Lei 6.697, de 10 de outubro de 1979, denominada Código de Menores, manteve a ordem jurídica prevista no Código de 1927, uma diferença marcante foi a visão terapêutica ou de tratamento com relação ao infrator, mas com relação ao processo de internamento predominava a visão moralista. O termo "situação irregular" também é marcante nesta legislação, e compreendia a privação de condições de subsistência, de saúde, de instrução, por omissão dos pais ou responsáveis, além da situação de maus-tratos e castigos, de perigo moral, de falta de assistência legal, de desvio de conduta por inadaptação familiar ou comunitária, e autoria de infração penal. ${ }^{25}$

A legislação menorista confirmava e reforçava a concepção de incapacidade das famílias pobres em educar os filhos. Neste sentido vale citar Rizzini:

“O novo Código de Menores, instaurado em 1979, criou a categoria de 'menor em situação de irregular', que, não muito diferente da concepção vigente no antigo Código de 1927, expunha as famílias populares à intervenção do Estado, por sua condição de pobreza". 26

Portanto, esta legislação se caracterizava pela sua visão autoritária da política; pelo poder centralizador do Executivo e do juiz; pela repressão aos marginais, como anti-sociais; pelo

\footnotetext{
24 Apud. DIDONET, Vital. Representação da Criança na Sociedade Brasileira. Infância e Desenvolvimento: Desafios e Propostas, Organizadores Antônio Rocha Magalhães e Walter Garcia, Brasília: IPEA, Série IPEA; n.140, 1993.

${ }^{25}$ LEI 6.697, de 10 de outubro de 1979. Dispõe sobre o Código de Menores.

${ }^{26}$ RIZZINI, Irene; RIZZINI, Irmã. A Institucionalização de Crianças no Brasil: percurso histórico e desafios do presente. Editora PUC, Rio de Janeiro: 2002.
} 
internamento e tratamento dos marginalizados ou periferizados, não integrados; pela visão da família e da criança como responsáveis pelas irregularidades; pelo controle do comportamento anti-social; pelo controle da assistência pela tecnocracia e pelos convênios; pelo arbítrio e arbitrariedade do juiz; pela ausência de direitos do menor na sua defesa; pela prisão cautelar de menores, para apurar infração penal grave; pelo internamento por condições de pobreza; pelo abrigamento de crianças; e pela centralização executiva. ${ }^{27}$

Os amplos poderes mantidos aos magistrados não demoraram a ser questionados e combatidos pelos movimentos sociais, com a transição democrática.

Em 1985 o Governo da chamada Nova República implanta diferentes ações frente a crise, de caráter paliativo e assistencialista, reforçando a estratégia de encaminhamento da criança ao trabalho e de clientelismo. Ao mesmo tempo, observa-se o impulsionamento de projetos alternativos, principalmente com o apoio da Fundação das Nações Unidas para a Infância - UNICEF, a articulação com grande número de entidades não governamentais.

Os projetos se desenvolvem por meio de organizações não governamentais em áreas bastante heterogêneas que enfatizavam ações como cerâmica, formação profissional, venda de produtos, alfabetização, ensino religioso, com forte presença de atores religiosos. A partir da articulação desses projetos surge o Movimento Nacional de Meninos e Meninas de Rua (MNMMR), fundado em 1985, que realiza três encontros nacionais em Brasília e que contribuíram significativamente para trazer a questão da política para a infância como debate nacional. As crianças e adolescentes apareceram como sujeitos de direitos como cidadãos.

A partir das lutas e pressões sociais, e dentro das correlações de forças possíveis, em 1986, o Congresso Nacional funciona como Assembléia Constituinte. Surgia então uma nova ordem jurídica política e social para a sociedade, com a Constituição Federal de 1988.

Com a nova ordem jurídica advinda da Constituição de 1988 os direitos da criança e do adolescente perpassam as diferentes áreas, mas ficam bem estabelecidos nos artigos 227, 228, e

\footnotetext{
${ }^{27}$ FALEIROS. Vicente de Paulo. Uma Década de Direitos: Avaliação dos dez anos de Estatuto da Criança e do Adolescente. Série Escola de Conselhos. Cadernos para a Cidadania. Brasília: CECRIA, 2000.
} 
229 da referida Constituição. Garante-se à criança e ao adolescente, como dever do Estado e da sociedade os direitos à vida, saúde, educação, ao lazer, à profissionalização, cultura, dignidade, ao respeito, liberdade, e à convivência familiar e comunitária, além de colocá-los a salvo de toda a forma de negligência, discriminação, exploração, violência, crueldade e opressão.

O processo de ruptura não se realizou de forma abrupta, mas num constante conflito que, reflete a correlação de forças sociais entre os que defendem posições de repressão, assistencialismo, cidadania e outros que defendem o mercado em primeiro lugar.

Ainda como forma de regular as disposições da Constituição Federal de 1988 surge a Lei ${ }^{\circ}$ 8.069, de 13 de julho de 1990, denominada Estatuto da Criança e do Adolescente - ECA regulamentou o art. 227 da Constituição de 1988, que estabelece os direitos fundamentais da criança e do adolescente. Além disso, o Estatuto hamoniza-se com a Convenção sobre os Direitos da Criança e do Adolescente, aprovada pela Assembléia Geral das Nações Unidas, em 20 de novembro de 1989.

Ao contrário das leis que nasceram em gabinetes o Estatuto da Criança e do Adolescente é fruto de uma intensa mobilização da sociedade civil. A partir de 1986, quando o país se preparava para redigir uma nova Constituição, teve início um movimento de entidades da sociedade civil para influenciar a Assembléia Nacional Constituinte a favor da infância e da adolescência.

Com o Estatuto da Criança e do Adolescente - ECA a criança e o adolescente são considerados cidadãos protagonistas de sua trajetória de acordo com o seu desenvolvimento, as crianças e adolescentes passam a gozar de todos os direitos fundamentais inerentes à pessoa humana e devem ter prioridade absoluta da família da sociedade e do Estado; é estabelecido o fim da política de abrigamento, a não ser em casos excepcionais; é instituída a prioridade das medidas de proteção sobre as medidas sócio educativas, deixando-se de focalizar a política da infância nos abandonados e delinqüentes. $^{28}$

\footnotetext{
${ }^{28}$ FALEIROS. Vicente de Paulo. Uma Década de Direitos: Avaliação dos dez anos de Estatuto da Criança e do Adolescente. Série Escola de Conselhos. Cadernos para a Cidadania. Brasília: CECRIA, 2000.
} 
Quando aos infratores é garantido o devido processo penal para o adolescente a quem se atribua prática de ato infracional; são estabelecidas as limitações dos poderes da autoridade judiciária e a implementação dos Conselhos Tutelares como instância socioeducacional colegiada escolhida pela comunidade; e ainda definiu a implementação de mecanismos de proteção dos interesses difusos e coletivos. ${ }^{29}$

A participação e o controle social são garantidos na deliberação sobre as políticas de infância e do adolescente por meio dos Conselhos de Direitos, em todos os níveis de governo como órgãos paritários; e é estabelecida a integração e articulação de ações governamentais e nãogovernamentais na política de atendimento. ${ }^{30}$

Deste modo o ECA significa um grande avanço para a Política de Proteção aos Direitos da Criança e do Adolescente que em síntese se dividiu, historicamente, em três momentos: o primeiro é o predomínio da caridade e da filantropia, o segundo a consolidação do sistema jurídicoadministrativo e o terceiro a criança e o adolescente como sujeito de direitos.

\subsection{O Estado Democrático de Direito e a Proteção aos Direitos da Criança e do Adolescente}

Os princípios e concepções trazidas pelo ECA consideram a doutrina de proteção integral como base e sistema de garantia dos direitos da criança e do adolescente. As crianças e os adolescentes não são mais considerados menores ou incapazes, mas pessoas em desenvolvimento para se tornarem protagonistas e sujeitos de direitos e passarem a assumir plenamente suas responsabilidades dentro da comunidade, em função do pleno desenvolvimento de sua personalidade.

A doutrina da proteção integral está contextualizada num processo histórico de construção de uma nova institucionalidade emergente na sociedade brasileira, em ruptura com as

\footnotetext{
${ }^{29}$ FALEIROS. Vicente de Paulo. Uma Década de Direitos: Avaliação dos dez anos de Estatuto da Criança e do Adolescente. Série Escola de Conselhos. Cadernos para a Cidadania. Brasília: CECRIA, 2000.

${ }^{30}$ Ibidem.
} 
dimensões inerentes a um padrão de relações autoritários, centralizado, repressivo, clientelista e de políticas fragmentadas.

O Estatuto da Criança e do Adolescente prevê em seu texto a criação do Sistema de Garantia de Direitos proposto para uma gestão articulada dos direitos da infância e adolescência. ${ }^{31}$ O Artigo 86 do Estatuto da Criança e do Adolescente, por exemplo, determina que "a política de atendimento de criança e do adolescente far-se-á por meio de um conjunto articulado de ações governamentais e não-governamentais da União, dos estados, do Distrito Federal e dos municípios".

De acordo com a socióloga, Marlene Vaz, o sistema surgiu da necessidade de se interpretar essa determinação do ECA. O Sistema de Garantia de Direitos da Criança e do Adolescente compreende três eixos de atuação: promoção, controle social e defesa dos direitos. ${ }^{32}$

A promoção tem por objetivo específico o atendimento direto, que pretende garantir o acesso universal e prioritário de crianças e adolescentes aos serviços públicos básicos, como assistência, educação e saúde. Nesse espaço também se encontram políticas e órgãos de proteção e atendimento de direitos de crianças e adolescentes. O instrumento para concretizar estes objetivos é a elaboração das próprias políticas sociais e, na sua falta, os programas especiais de atenção.

O controle tem objetivo de exercer vigilância sobre a política e o uso de recursos públicos para a área da infância e da adolescência, bem como o monitoramento e controle tanto de ações de organizações não-governamentais quanto de órgãos governamentais. É um espaço de sociedade civil organizada, representada nos fóruns, frentes, pactos, e dos Conselhos de Direitos.

A defesa tem por objetivo específico verificar o não atendimento, o atendimento irregular ou a violação dos direitos da criança e do adolescente. É o espaço de Conselhos Tutelares, Poder Judiciário (especialmente Juizado da Infância e da Juventude), Ministério Público, Secretarias da Justiça (órgãos de defesa da cidadania), Secretaria de Segurança Pública (Polícias), Defensoria

\footnotetext{
${ }^{31}$ Embora não exista na legislação brasileira nenhuma menção específica a essa rede, a idéia de articulação está presente nas leis.

${ }^{32}$ Apud. VIVARTA, Veet (coord). Ouvindo Conselhos: democracia participativa e direitos da infância na pauta das redações brasileiras. São Paulo: Cortez, 2005.
} 
Publica, Ordem dos Advogados do Brasil, Centros de Defesa da Criança e do Adolescente e outras associações legalmente constituídas.

O Estado Democrático de Direito é instituído no art. $1^{\circ}$ da Constituição Federal de 1988. isto quer dizer que os valores da democracia devem irradiar todos os elementos constitutivos do estado. Neste sentido o direito imantado por estes valores deve seguir o interesse coletivo.

Neste Estado a democracia, então, será realizada por meio de um processo de convivência social, levando em conta que o poder emana do povo e em nome dele deve ser exercido, propiciando a participação do povo no processo decisório, respeitando a pluralidade de idéias e de opiniões. Logo, o Estado Democrático de Direito tem um papel fundamental de realizar a síntese do processo contraditório do mundo contemporâneo, "superando" o Estado capitalista para configurar um Estado promotor de justiça social. Reforçando tal entendimento vale citar José Afonso da Silva, verbis:

“A democracia que o Estado Democrático de Direito realiza há de ser um processo de convivência social livre, justa e solidária (art.3 $3^{\circ}, \mathrm{I}$ ), que o poder emana do povo, e deve ser exercido em proveito do povo, diretamente ou por representantes eleitos (art. $1^{\circ}$, parágrafo único); participativa, porque envolve a participação crescente do povo no processo decisório e na formação dos atos de governo; pluralista, porque respeita a pluralidade de idéias, culturais e etnias e pressupõem assim o diálogo entre opiniões e pensamentos divergentes e a possibilidade de convivência de formas de organização de interesses diferentes da sociedade; há de ser um processo de libertação da pessoa humana das formas de opressão que não depende apenas do reconhecimento formal de certos direitos individuais, políticos e sociais, mas especificamente da vigência de condições econômicas suscetíveis de favorecer o seu pleno exercício". 33

Portanto, está presente nos valores da Constituição de 1988 a possibilidade de participação social no processo decisório, o que legitima a criação dos Conselhos de Direitos como órgãos pertencentes ao sistema descentralizado de gestão das políticas públicas, para entender melhor como este processo irá ocorrer se faz necessário compreender o sistema federativo.

Quanto à forma de Estado o Brasil optou pelo federalismo que consiste na reunião de vários Estados num só, cada qual com certa independência, autonomia interna, mas obedecendo

${ }^{33}$ SILVA, José Afonso. Curso de Direito Constitucional Positivo. São Paulo: Malheiros, 2005. 
todos a uma Constituição única. Com esta forma de estado o país pretendeu descentralizar o poder, cabendo a todos os Estados, Município e Distrito Federal uma parcela de responsabilidade nas decisões do país. ${ }^{34}$

Deste modo podemos concluir que o sistema federativo permite a descentralização da decisão e a repartição de poderes e responsabilidades. Neste sentido não é apenas ao Governo Federal que cabe à execução e fiscalização da Política de Proteção aos Direitos da Criança e do Adolescente, os Estados e Municípios também são responsáveis neste processo de descentralização de poder.

A nova institucionalização implica não só uma democratização do Estado, mas um processo de participação da sociedade na gestão pública, principalmente, por meio da implementação de conselhos paritários, com o poder de decisão sobre determinados temas. Há, portanto, uma nova, relação de poder, que traduz, evidentemente, na arena política, conflitos vigentes não só entre instituinte e o instituído, mas a emergência de tensões entre atores que entram em cena e aqueles que vinham detendo o poder hegemônico.

A concepção de controle social advém da Constituição Federal de 1988, momento político-ideológico em que a participação popular e os mecanismos de efetivação da democracia são garantidos na lei maior. O controle social é um mecanismo democrático no processo de gestão político-administrativa-financeira e técnico-operativa e uma possibilidade de participação da sociedade na gestão de políticas públicas.

Segundo Raichelis controle social ou democracia direta consiste na participação da sociedade civil, na gestão e organização das entidades públicas e privadas. ${ }^{35}$ Esta participação se dá por meio dos Fóruns, Conferências, e especialmente por meio dos Conselhos de Direitos, que são órgãos normativo, deliberativo e fiscalizador da Política Social, sendo este órgão integrante do sistema descentralizado.

\footnotetext{
${ }^{34}$ SILVA, José Afonso. Curso de Direito Constitucional Positivo. São Paulo: Malheiros, 2005.

${ }^{35}$ RAICHELIS, Raquel. Esfera Pública e Conselhos de Assistência Social: caminhos da construção democrática. São Paulo: Cortez, 1998.
} 


\subsubsection{Os Conselhos de Direitos e o Controle Social}

No dicionário Aurélio o termo "conselho" é definido como: 1) parecer, juízo, definição, opinião; 2) advertência, aviso; 3) prudência; 4) corpo coletivo superior; 5) tribunal; 6) reunião ou assembléia de ministros; 7) corporação à qual incumbe opinar aconselhar sobre certos negócios públicos; 8) reunião de pessoas para tratarem de assunto particular; e 9) reunião de professores para tratarem de assuntos de ensino ou de ordem. Apesar de algumas definições se aproximarem do significado de Conselho de Direitos a concepção posta na legislação é mais específica.

No caso da assistência social a Lei Orgânica da Assistência Social - LOAS em seu art. $5^{\circ}$ prevê a participação popular, com base na descentralização político-administrativa para os Estados, Distrito Federal e Municípios, o comando único em cada esfera de governo, e a primazia da responsabilidade do Estado na condução da política de assistência social em cada esfera de governo. E no art. 16. prevê a criação dos Conselhos de Assistência Social como instâncias deliberativas do sistema descentralizado e participativo de assistência social, de caráter permanente e composição paritária entre governo e sociedade civil

Para o Estatuto da Criança e do Adolescente - ECA, especialmente nos arts. 88 a 91, os Conselhos de Direitos e os Conselhos Tutelares são entendidos como mecanismos democráticos de participação e representação política da sociedade civil na gestão políticoadministrativa do Estado.

Neste sentido segundo Orlando Alves dos Santos Junior "os conselhos estão se consolidando como uma arena de interação entre o governo e a sociedade" ${ }^{36}$, sendo estes de acordo com Rubem Sião Praestes, sem dúvida, a "maior alteração produzida na administração pública brasileira nos últimos tempos". 37

\footnotetext{
${ }^{36}$ Apud. VIVARTA, Veet (coord). Ouvindo Conselhos: democracia participativa e direitos da infância na pauta das redações brasileiras. São Paulo: Cortez, 2005.

${ }^{37}$ Ibidem.
} 
Atuando na defesa e na proteção dos direitos das crianças e adolescentes do Distrito Federal destaca-se, dentre outros ${ }^{38}$, o Conselho da Assistência Social - CAS/DF, o Conselho de Direitos da Criança e do Adolescente - CDCA/DF.

No âmbito da proteção dos direitos da criança e do adolescente no Distrito Federal a política de controle social é realizada pelo Conselho de Assistência Social do Distrito Social CAS/DF e pelo Conselho dos Direitos da Criança e do Adolescente - CDCA/DF, conforme o quadro abaixo:

Tabela 1. Como se dá a execução e o controle social da Política de Proteção aos Direitos da Criança e do Adolescente

\begin{tabular}{|c|c|c|}
\hline Programas & $\begin{array}{l}\text { Órgão responsável pela } \\
\text { execução da Política }\end{array}$ & $\begin{array}{l}\text { Órgão responsável pelo } \\
\text { Controle Social }\end{array}$ \\
\hline \multirow{2}{*}{$\begin{array}{l}\text { Programa e Defesa dos } \\
\text { Direitos da Criança e do } \\
\text { Adolescente }\end{array}$} & $\begin{array}{l}\text { No âmbito Federal é a Secretaria } \\
\text { Especial dos Direitos Humanos. }\end{array}$ & $\begin{array}{llll}\text { No âmbito } & \text { Federal é } & \text { o } \\
\text { CONANDA. } & & & \\
\end{array}$ \\
\hline & $\begin{array}{l}\text { No âmbito do Distrito Federal é } \\
\text { a Secretaria de Justiça e de } \\
\text { Direitos Humanos. }\end{array}$ & $\begin{array}{l}\text { No âmbito do Distrito Federal é } \\
\text { o CDCA/DF. }\end{array}$ \\
\hline \multirow{2}{*}{$\begin{array}{l}\text { Programa de Atendimento } \\
\text { Sócio Educativo ao } \\
\text { Adolescente em conflito } \\
\text { com a Lei }\end{array}$} & $\begin{array}{l}\text { No âmbito Federal é a Secretaria } \\
\text { Especial dos Direitos Humanos }\end{array}$ & $\begin{array}{llll}\text { No âmbito } & \text { Federal é } & \text { o } \\
\text { CONANDA } & & & \end{array}$ \\
\hline & $\begin{array}{l}\text { No âmbito do Distrito Federal é } \\
\text { a Secretaria de Justiça e de } \\
\text { Direitos Humanos. }\end{array}$ & $\begin{array}{l}\text { No âmbito do Distrito Federal é } \\
\text { o CDCA/DF. }\end{array}$ \\
\hline \multirow[b]{2}{*}{$\begin{array}{l}\text { Combate ao Abuso e à } \\
\text { Exploração Sexual de } \\
\text { Crianças e Adolescentes }\end{array}$} & $\begin{array}{l}\text { No âmbito Federal é a Secretaria } \\
\text { Especial dos Direitos Humanos. }\end{array}$ & $\begin{array}{l}\text { No âmbito Federal é } \\
\text { CONANDA. }\end{array}$ \\
\hline & $\begin{array}{l}\text { No âmbito do Distrito Federal é } \\
\text { a Secretaria de Justiça e de } \\
\text { Direitos Humanos. }\end{array}$ & $\begin{array}{l}\text { No âmbito do Distrito Federal é } \\
\text { o CDCA/DF. }\end{array}$ \\
\hline \multirow{2}{*}{$\begin{array}{l}\text { Projeto Agente Jovem de } \\
\text { Desenvolvimento Humano }\end{array}$} & $\begin{array}{l}\text { No âmbito Federal é o } \\
\text { Ministério do Desenvolvimento } \\
\text { Social. }\end{array}$ & No âmbito Federal é o CNAS. \\
\hline & $\begin{array}{l}\text { No âmbito Distrito Federal é a } \\
\text { Secretaria de Ação Social - } \\
\text { SEAS. }\end{array}$ & $\begin{array}{l}\text { No âmbito do Distrito Federal é } \\
\text { o CAS/DF. }\end{array}$ \\
\hline
\end{tabular}

${ }^{38}$ Com o exemplo de Conselhos que atuam na defesa dos direitos da criança e do adolescente pode-se citar o Conselho da Saúde, da Educação, da Assistência Social, dos Direitos da Criança e do Adolescente, etc. 


\begin{tabular}{|c|c|c|}
\hline \multirow[t]{2}{*}{ Ações Sócio Educativas } & $\begin{array}{l}\text { No âmbito } \quad \text { Federal é ó } \\
\text { Ministério do Desenvolvimento } \\
\text { Social. }\end{array}$ & No âmbito Federal é o CNAS. \\
\hline & $\begin{array}{l}\text { No âmbito Distrito Federal é a } \\
\text { Secretaria de Ação Social - } \\
\text { SEAS. }\end{array}$ & $\begin{array}{l}\text { No âmbito do Distrito Federal é } \\
\text { o CAS/DF. }\end{array}$ \\
\hline \multirow{2}{*}{$\begin{array}{l}\text { Serviços Continuados para } \\
\text { Atendimento à Criança } \\
\text { (BPC) }\end{array}$} & $\begin{array}{l}\text { No âmbito } \text { Federal é ó } \\
\text { Ministério do Desenvolvimento } \\
\text { Social. }\end{array}$ & No âmbito Federal é o CNAS. \\
\hline & $\begin{array}{l}\text { No âmbito Distrito Federal é a } \\
\text { Secretaria de Ação Social - } \\
\text { SEAS. }\end{array}$ & $\begin{array}{l}\text { No âmbito do Distrito Federal é } \\
\text { o CAS/DF. }\end{array}$ \\
\hline \multirow{2}{*}{$\begin{array}{c}\text { Proteção Especial de } \\
\text { Média Complexidade } \\
\text { (Centros de Referência } \\
\text { Especializados de } \\
\text { Assistência Social - } \\
\text { CREAS*) }\end{array}$} & $\begin{array}{l}\text { No âmbito Distrito Federal é a } \\
\text { Secretaria de Ação Social - } \\
\text { SEAS. }\end{array}$ & No âmbito Federal é o CNAS. \\
\hline & $\begin{array}{l}\text { No âmbito Distrito Federal é a } \\
\text { Secretaria de Ação Social - } \\
\text { SEAS. }\end{array}$ & $\begin{array}{l}\text { No âmbito do Distrito Federal é } \\
\text { o CAS/DF. }\end{array}$ \\
\hline \multirow{2}{*}{$\begin{array}{l}\text { Proteção Especial de Alta } \\
\text { Complexidade } \\
\text { (Programa de erradicação } \\
\text { do trabalho infantil - } \\
\text { PETI**, Sistema Único da } \\
\text { Assistência Social - } \\
\text { SUAS*** e Serviços de } \\
\text { proteção à criança e } \\
\text { adolescente vítima de } \\
\text { violência, abuso e } \\
\text { exploração sexual****) }\end{array}$} & $\begin{array}{l}\text { No âmbito Federal é o o } \\
\text { Ministério do Desenvolvimento } \\
\text { Social. }\end{array}$ & No âmbito Federal é o CNAS. \\
\hline & $\begin{array}{l}\text { No âmbito Distrito Federal é a } \\
\text { Secretaria de Ação Social - } \\
\text { SEAS. }\end{array}$ & $\begin{array}{l}\text { No âmbito do Distrito Federal é } \\
\text { o CAS/DF. }\end{array}$ \\
\hline
\end{tabular}

*Serviços de media complexidade são aqueles que oferecem atendimentos às famílias e indivíduos com seus direitos violados, mas cujos vínculos familiares e comunitários não foram rompidos. Neste sentido, requerem maior estruturação técnicooperacional e atenção especializada e mais individualizada, e, ou, de acompanhamento sistemático e monitorado. Estas atividades são desenvolvidas pelos Centros de Referência Especializados de Assistência Social.

** O PETI é um programa de transferência direta de renda para famílias de crianças e adolescentes em situação de trabalho, adicionado à oferta de Ações Socioeducativas e de Convivência, manutenção da criança/adolescente na escola e articulação dos demais serviços da rede de proteção básica e especial.

*** O SUAS hoje é o objetivo da Política de Assistência Social, inspirado no SUS, pretende facilitar o acesso à assistência social.

**** Serviço que oferece um conjunto de procedimentos técnicos especializados para atendimento e proteção imediata às crianças e aos adolescentes vítimas de abuso ou exploração sexual, bem como seus familiares, proporcionando-lhes condições para o fortalecimento da auto-estima, superação da situação de violação de direitos e reparação da violência vivida.

\subsubsection{O Conselho de Assistência Social do Distrito Federal - CAS/DF}

O Conselho de Assistência Social do Distrito Federal - CAS/DF foi criado pela Lei n 997, de 29 de dezembro de 1995, como órgão público de caráter permanente e competência 
normativa e deliberativa na formulação da Política de Assistência Social, integrante do sistema descentralizado de Assistência Social, vinculado administrativamente à Secretaria de Desenvolvimento Social e Ação Comunitária do Distrito Federal ${ }^{39}$, responsável pela coordenação e execução da Política de Assistência Social do Distrito Federal.

Sua criação está fundamentada na Lei Orgânica de Assistência Social - LOAS, Lei $\mathrm{n}^{\mathrm{o}} 8.742$, de 7 de dezembro de 1993, que em seu artigo $9^{\text {a }}$, prevê que o funcionamento das entidades e organizações de assistência social depende de prévia inscrição no respectivo Conselho Municipal de Assistência Social, ou no Conselho de Assistência Social do Distrito Federal, conforme o caso.

Ainda de acordo com o artigo 16 da LOAS, o Conselho de Assistência Social do Distrito Federal serão instâncias deliberativas do sistema descentralizado e participativo de assistência social, de caráter permanente e composição paritária entre governo e sociedade civil.

O CAS/DF é composto, de forma colegiada e paritária, por representantes de órgãos públicos e por representantes de usuários da Assistência Social, trabalhadores da área de Assistência Social e entidades não-governamentais prestadoras de serviços, benefícios, assessoramento e defesa de direitos, devidamente inscrita no CAS/DF.

O CAS/DF é composto de 20 Conselheiros titulares e os respectivos suplentes, nomeados pelo Governador do Distrito Federal.

Os 10 representantes do Governo serão indicados pelos seguintes órgãos: Secretaria de Ação Social; Secretaria de Trabalho e Direitos Humanos; Secretaria de Saúde; Secretaria de Desenvolvimento Social; Secretaria de Infra-Estrutura e Obras; Secretaria de Governo; Secretaria de Educação; Secretaria de Cultura; Secretaria da Fazenda e Planejamento; e Universidade de Brasília - UnB.

${ }^{39}$ Apesar da Lei acima mencionar a Secretaria de Desenvolvimento Social e Ação Comunitária do Distrito Federal, hoje (2007) ela é denominada de Secretaria de Ação Social - SEAS, e o CAS/DF é órgão vinculado à esta Secretaria, mesmo a Lei não deixando claro, vale salientar que a instituição, mesmo estando vinculada à SEAS, é um órgão autônomo na normatização e deliberação sobre a política de assistência social, tendo inclusive recursos próprios. 
Os 10 membros da sociedade civil devem representar entidades não governamentais de prestação de serviços, assessoramento e defesa, organizações dos destinatários da Assistência Social e trabalhadores da área, escolhidos em Assembléia especialmente reunida para este fim pelo voto da maioria dos presentes, sob a fiscalização do Ministério Público do Distrito Federal e Territórios. Ficando assegurados a representação do Governo e da Sociedade Civil na Presidência e Vice-Presidência do CAS/DF, e a alternância dessas representações em cada mandato, e assim sucessivamente, com exceção dos casos de recondução por igual período.

Diante desta exigência da Lei Federal os Municípios e o Distrito Federal tiveram que reorganizar a Assistência Social, criando os Conselhos de Assistência Social que tem por finalidade fiscalizar e normatizar a Política de Assistência Social dos Municípios e do Distrito Federal.

O CAS/DF definiu em seu Regimento Interno ${ }^{40}$, como objetivos de atuação institucional efetivar, no âmbito do Distrito Federal, o processo descentralizado e participativo da Assistência Social, previsto na Constituição Federal, na LOAS e na Lei Orgânica do Distrito Federal; aprovar, com base nas prioridades e diretrizes estabelecidas pela Conferência de Assistência Social do Distrito Federal, proposta de Política de Assistência Social a ser encaminhada pela Secretaria de Ação Social do Distrito Federal; funcionar em articulação com o Conselho Nacional de Assistência Social - CNAS, Conselhos Distritais congêneres e órgãos formuladores e executivos de políticas setoriais de desenvolvimento sócio-econômico, mantendo interfaces com estes diferentes organismos; atuar em consonância com as normas, critérios, políticas e orientações emanadas do CNAS; zelar pela transparência da Política de Assistência Social no Distrito Federal; e respaldar a Política de Assistência Social em atividades permanentes de estudos, pesquisas e capacitação de recursos humanos, preservando a sua qualidade e adequação à realidade do Distrito Federal.

O CAS/DF contribui para a Política de Assistência Social na realização da Conferência de Assistência Social, que é um espaço amplo e aberto para a deliberação e apontamentos dos rumos da Assistência Social do Distrito Federal. As informações e deliberações desta Conferência serão apresentadas na Conferência Nacional de Assistência Social, junto com as

\footnotetext{
${ }^{40}$ DISTRITO FEDERAL. Resolução no 12, de 6 de agosto de 2002, Dispõe sobre o Regimento Interno do Conselho de Assistência Social do Distrito Federal - CAS/DF.
} 
demais deliberações dos Estados e Municípios. A Conferência Nacional é organizada pelo Conselho Nacional de Assistência Social - CNAS, órgão vinculado à esfera federal e responsável pela elaboração do Plano Nacional de Assistência Social.

As decisões aprovadas no Plano Nacional de Assistência Social devem ser implementadas nos Estados, Distrito Federal e Municípios, cabendo aos Conselhos de Assistência Social, integrante do sistema descentralizado, o acompanhamento, a fiscalização e o controle desta política.

O atual Plano Nacional de Assistência Social ${ }^{41}$ prevê que para a consolidação da assistência como uma política social seria necessária a implementação do Sistema Único de Assistência Social - SUAS, cujo fundamento é o pacto federativo. Mas a centralização ainda é uma marca a ser superada.

Ainda para dar maior eficiência e eficácia a esta política são necessários a construção de redes sociais e o fortalecimento dos órgãos de controle social. Neste sentido reafirmase a importância do Conselho de Assistência Social do Distrito Federal - CAS/DF como órgão normativo e fiscalizador da Política de Assistência Social.

Contudo, verifica-se que as atividades do Conselho, ainda estão relacionadas com a burocracia de procedimentos o que impede muitas vezes a efetivação de todas suas competências, ainda há que se destacar a falta de capacitação constante para os conselheiros que muitas vezes não conseguem interferir de forma adequada na questão orçamentária, e da própria política.

Os próprios mecanismos de controle e fiscalização efetiva das entidades ainda são deficientes uma vez que a visita institucional para realizar a fiscalização da entidade, só é realizada no momento do pedido de inscrição ou de revalidação da inscrição do CAS/DF, que se dá a cada 5 anos. Durante este intervalo as entidades devem enviar anualmente a prestação de contas, entretanto o CAS/DF não tem como acompanhar esta prestação de contas, por falta de pessoal especializado, o que gera uma fiscalização ineficaz, não sistemática e descontinuada das entidades.

\footnotetext{
${ }^{41} \mathrm{O}$ atual Plano Nacional de Assistência Social foi publicado no dia 28 de outubro de 2004, e tem validade por até 2008, ano em que será elaborado novo Plano Nacional de Assistência Social. A próxima Conferência de Assistência do Distrito Federal ocorrerá em meados de outubro de 2007.
} 
Percebe-se também que o CAS/DF não efetiva sua competência de ser o divulgador das políticas de assistência social, sendo um dever também deste conselho divulgar a política de assistência social, visando seu aperfeiçoamento e valorização.

Portanto, quanto à competência do CAS/DF percebe-se que ainda faltam aspectos a serem organizados para que a Instituição possa exercer suas atribuições de forma plena.

\subsubsection{O Conselho dos Direitos da Criança e do Adolescente do Distrito Federal - CDCA/DF}

O Conselho dos Direitos da Criança e do Adolescente do Distrito Federal CDCA/DF é regulamentado pela Lei $\mathrm{n}^{\mathbf{0}}$ 3033, de 18 de julho de 2002, como órgão deliberativo e controlador das ações da política de atendimento aos direitos da criança e do adolescente, fica vinculado administrativamente à Secretaria de Estado de Ação Social do Distrito Federal ${ }^{42}$, que proporcionará os meios necessários ao seu funcionamento.

A criação do CDCA/DF advém da própria previsão da Constituição Federal de 1988 e do Estatuto de Criança e do Adolescente que cria um Sistema de Garantias, onde os Conselhos de Direitos e os Conselhos Tutelares têm papel fundamental.

De acordo com a Lei 3.033, de 18 de julho de 2002, o CDCA/DF tem como atribuições formular a política de proteção dos direitos da criança e do adolescente e definir suas prioridades; controlar e acompanhar as ações governamentais e não-governamentais na execução da política de atendimento dos direitos da criança e do adolescente; gerir o Fundo dos Direitos da Criança e do Adolescente do Distrito Federal, de que trata o art. $9^{\circ}$ da Lei $\mathrm{n}^{\circ} 234$, de 15 de janeiro de 1992, modificada pela Lei n ${ }^{o}$ 518, de 30 de julho de 1993, definindo a política de captação, administração e aplicação dos seus recursos financeiros; assessorar o Poder Executivo na elaboração da proposta orçamentária, no que se refere à destinação de recursos públicos para as áreas relacionadas com a política de atendimento aos direitos da criança e do adolescente; inscrever, na forma das normas a serem fixadas, os programas governamentais e não-governamentais, observado o disposto no art. 90 do Estatuto da Criança e do Adolescente; registrar, na forma das normas a serem

\footnotetext{
${ }^{42}$ Em 2007 após a posse do novo Governador de Estado, José Roberto Arruda, o CDCA/DF é vinculado ao PróConselhos órgão da Secretaria de Justiça e de Direitos Humanos.
} 
fixadas, as organizações não-governamentais com atuação na área da infância e da adolescência no Distrito Federal, observado o disposto no art. 91 do Estatuto da Criança e do Adolescente; propor e acompanhar, sempre que necessário, o reordenamento institucional, indicando modificações nas estruturas públicas e privadas destinadas ao atendimento da criança e do adolescente; promover, apoiar e incentivar a realização de estudos, pesquisas e eventos sobre a política e as ações de atendimento dos direitos da criança e do adolescente; avaliar a política e as ações de atendimento dos direitos da criança e do adolescente no âmbito do Distrito Federal; regulamentar, organizar e coordenar o processo de escolha dos membros dos Conselhos Tutelares; apoiar os Conselhos Tutelares e os órgãos governamentais e não-governamentais para tornar efetivos os direitos da criança e do adolescente estabelecidos na Lei Federal nº 8.069, de 1990; convocar, ordinariamente, a cada dois anos, a Conferência Distrital dos Direitos da Criança e do Adolescente, para avaliar a política e as ações de atendimento dos direitos da criança e do adolescente no Distrito Federal e propor diretrizes para o seu aperfeiçoamento; realizar e incentivar a realização de campanhas promocionais e de conscientização dos direitos da criança e do adolescente; e cumprir o seu regimento interno.

Quanto à política de proteção ao direito da criança e do adolescente o CDCA/DF segue as orientações do CONANDA, quanto às prioridades de intervenção da política, que em 1996 definiu como eixos prioritários de intervenção o trabalho infantil, a violência e a exploração sexual e o ato infracional (medida sócio-educativa), o que representou um significativo avanço para a Política de Proteção aos direitos da criança e do adolescente. Neste sentido vale citar a seguinte passagem:

"A iniciativa do Conselho Nacional em debater esses eixos em assembléias ampliadas obteve boa repercussão junto aos Estados, sobretudo, quanto ao incentivo para que a discussão acontecesse de forma ampla, resultado em intensa mobilização, não apenas entre os Conselhos como também entre as diversas entidades e organizações da área. Os três eixos contribuíram para o trabalho dos Conselhos Estaduais que fazem seu acompanhamento e implementação, mediante comissões, parcerias com ONGs, diagnóstico e elaboração de subsídios. (...) As diretrizes do CONANDA também contribuíram para a formulação do Plano de Ação do Departamento da Criança e do Adolescente do Ministério da Justiça, voltado especialmente para o atendimento ao adolescente em conflito com a lei." ${ }^{3}$

\footnotetext{
${ }^{43}$ Apud. FALEIROS. Vicente de Paulo. Uma Década de Direitos: Avaliação dos dez anos de Estatuto da Criança e do Adolescente. Série Escola de Conselhos. Cadernos para a Cidadania. Brasília: CECRIA, 2000.
} 
O CDCA/DF é integrado por representantes do Poder Executivo e por organizações representativas da sociedade com atuação na área da infância e da adolescência no Distrito Federal, sendo paritária a participação do Governo e da Sociedade Civil. É composto por vinte membros titulares e seus respectivos suplentes.

Serão 10 (dez) dos membros do Governo (Poder Executivo), indicados pelos titulares da Secretaria de Estado de Ação Social; Secretaria de Estado de Cultura; Secretaria de Estado de Educação; Secretaria de Estado de Esporte e Lazer; Secretaria de Estado de Fazenda e Planejamento; Secretaria de Estado de Governo; Secretaria de Estado de Saúde; Secretaria de Estado de Segurança Pública; Secretaria de Estado de Trabalho e Direitos Humanos; Centro de Assistência Judiciária do Distrito Federal.

Os membros da Sociedade Civil também serão 10 (dez) representantes de organizações representativas da sociedade civil, legalmente constituídas, distribuídas da seguinte forma: a) 06 (seis) representantes com atuação na área de atendimento direto à infância e adolescência no Distrito Federal há mais de um ano e com registro no CDCA-DF; b) 02 (dois) representantes de entidades de classe que atuem na área da criança e do adolescente no Distrito Federal; c) 02 (dois) representantes de entidades de estudo, pesquisa e defesa de direitos que atuem no Distrito Federal há mais de um ano.

A escolha das organizações representativas da sociedade que farão parte do CDCA/DF será feita mediante eleição, realizada em assembléia especialmente convocada para este fim, pelo voto da maioria simples dos delegados presentes e sob fiscalização do Ministério Público do Distrito Federal.

O exercício da função de conselheiro é considerado de interesse público relevante e não será remunerado. Requer ainda o compromisso com a missão institucional do CDCA - DF e em relação a seu órgão ou sua organização, devendo atender aos requisitos como: o efetivo exercício de suas funções no seu órgão ou sua organização; formação acadêmica ou comprovada atuação na área da criança e do adolescente; pertencer, preferencialmente, à diretoria ou ocupar cargos diretivos na organização representativa. 
Vale ainda fazer uma diferenciação entre o perfil dos Conselhos de Direitos com relação aos Conselhos Tutelares, apesar deste não ser o tema principal deste Trabalho.

Quanto à função principal os Conselhos de Direitos são órgãos criados por lei para formular e deliberar sobre as políticas públicas relativas à criança e adolescente, em suas interfaces com as áreas de saúde, meio ambiente, assistência social e educação, por exemplo. Também devem organizar redes de atenção à população infanto-juvenil, promovendo a articulação das ações, das entidades e dos programas da sociedade civil e dos governos. Devem existir nos âmbitos municipal estadual e nacional. Já os Conselhos Tutelares também devem ser criados por lei (municipal) e cada cidade deve ter, no mínimo, um Conselho Tutelar. São encarregados de zelar pelo cumprimento dos direitos da criança e do adolescente, estando vinculados aos anseios e às demandas da sociedade em relação a esses segmentos etários. Têm função privilegiada na assessoria as poderes Executivo e Legislativo na elaboração do orçamento para planos e programas de atendimento dos direitos da criança e do adolescente. ${ }^{44}$

Quanto aos conselheiros percebe-se que os Conselhos de Direitos são formados paritariamente por integrantes do poder público e da sociedade civil, escolhidos em fórum próprio. A função dos conselheiros é considerada de interesse público relevante e não é remunerada. Já os Conselhos tutelares são formados por cinco membros escolhidos pela própria comunidade para mandato de três anos, por meio de eleição. Hoje, em boa parte dos municípios remunera-se a atividade de conselheiro tutelar, inclusive no Distrito Federal. ${ }^{45}$

Quanto à atuação de cada Conselho vale ressaltar que o Conselho Nacional dos Direitos da Criança e do Adolescente - CONANDA delibera sobre as questões de âmbito nacional, enquanto os Conselheiros Estaduais e Municipais têm como política de atendimento no âmbito dos estados e em nível local, respectivamente. Costumam ter Assembléias mensais e contar Comissões de Trabalho (Políticas Públicas, Orçamento, e Fundos, entre outros) formadas pelos conselheiros. Quando dispõem de uma secretaria executiva e grupo de apoio técnico, tem maior eficiência e agilidade nos encaminhamentos. Os Conselhos Tutelares atuam diretamente para a garantia da oferta

\footnotetext{
${ }^{44}$ Apud. VIVARTA, Veet (coord). Ouvindo Conselhos: democracia participativa e direitos da infância na pauta das redações brasileiras. São Paulo: Cortez, 2005.

${ }^{45}$ Ibidem.
} 
dos direitos. Para tanto, podem requisitar serviços públicos nas áreas de saúde e educação. Aqui acontece a relação é mais direta com a população que pode recorrer aos Conselhos Tutelares sempre que tiver um direito violado ou negado. Devem contar com sede, equipamentos e dispor de apoio técnico as diferentes áreas, fornecidos pelo Poder Executivo Municipal. ${ }^{46}$

Verifica-se que os Conselhos de Direitos são compostos de forma paritária e mantém certo grau de identidade entre si, contudo percebe-se que na prática estes Conselhos ainda não conseguiram desenvolver mecanismos que possam promover a articulação entre estes, com o objetivo de valorizar e o aperfeiçoar os Conselhos de Direitos como instrumentos de efetivação da democracia direta.

\subsection{Articulação entre os Conselhos para a Proteção dos Direitos da Criança e do Adolescente}

Como vimos a Política de Proteção aos Direitos da Criança e do Adolescente, bem como as políticas sociais, seguem os ideais previstos na Constituição de 1988, no que diz respeito à participação da sociedade civil na gestão das políticas públicas. Para exercerem o controle social foram previstos, dentre outros, os Conselhos de Direitos.

Os Conselhos são canais importantes de participação coletiva, que possibilitam a criação de uma nova cultura política e novas relações políticas entre governos e cidadãos. São também uma das mais legítimas formas de democracia direta. ${ }^{47}$

Os Conselhos de Direitos são órgãos previstos no Sistema de Garantias previsto no Estatuto da Criança e do Adolescente. Portanto, exercem uma função estratégica perante a Política de Proteção dos Direitos da Criança e do Adolescente, porque integram o sistema descentralizado de gestão governamental, e contam com a participação da sociedade civil na formulação, execução e avaliação desta política. A função dos Conselhos não é meramente consultiva, mas sim deliberativa.

\footnotetext{
${ }^{46}$ Apud. VIVARTA, Veet (coord). Ouvindo Conselhos: democracia participativa e direitos da infância na pauta das redações brasileiras. São Paulo: Cortez, 2005.

$47 \mathrm{Na}$ democracia direta, os cidadãos jamais delegam o seu poder de decisão. As decisões são tomadas em assembléias gerais. Se por acaso precisam de um representante, este só recebe os poderes que a assembléia quiser darlhe, os quais podem ser revogados a qualquer momento. Assim, na democracia direta, o poder do representante se assemelha ao que é conferido por um mandato comercial.
} 
Em termos da tradição política brasileira, os Conselhos de Direitos são entidades inéditas, conseqüência de uma conquista da sociedade civil para imprimir níveis crescentes de democratização na esfera pública, uma vez que em nosso país há uma forte trajetória de centralização e concentração de poder.

A composição paritária dos Conselhos, com representação da Sociedade Civil e do Governo, caracteriza os conselhos como instâncias de negociação de conflitos entre diferentes grupos e interesses, sendo, portanto um campo de disputas políticas, de conceitos e processos, de significados e resultantes políticos. ${ }^{48}$

As propostas democratizadoras do Estado e das políticas públicas, bem como a criação dos Conselhos vieram na contramão do fortalecimento de ideologias contrárias à universalização dos direitos sociais, aprofundando a privatização do público. Para reforçar tal posicionamento vale mencionar a seguinte afirmação de Raichelis:

"Muitos dos desafios atuais relacionam-se ao contexto adverso em que os conselhos foram implantados - de esvaziamento das responsabilidades públicas do Estado, de desqualificação das instâncias de representação coletivas, de fragmentação do espaço público e de despolitização da política, processos que fragilizam a capacidade de a sociedade civil exercer pressão direta sobre os rumos da ação estatal. Outras dificuldades decorrem da própria lógica de estruturação das políticas públicas na sociedade capitalista e da natureza da intervenção estatal nesse campo." 49

Como conseqüência desta característica centralizadora e de privatização do público as Políticas Sociais foram fragmentadas e setorizadas, na tentativa de dissolvê-las e fragiliza-las, uma vez que são contrárias ao paradigma neoliberal capitalista.

A Política de Proteção aos Direitos da Criança e do Adolescente obedece à lógica da setorização, em que a política é tida como partes segmentadas, sem comunicação e articulação.

${ }^{48}$ RAICHELIS, Raquel, A Articulação entre os conselhos de políticas públicas: uma pauta a ser enfrentada pela sociedade civil. Diponível em: $<$ http//LwWw.abong.org.br/novosite/download/4 raquel.pdf.

${ }^{49}$ Ibidem. 
Como conseqüiência deste processo ocorrem dificuldades na ação pública dirigida à implementação de políticas redistributivas que tenham reflexo na garantia de direitos. ${ }^{50}$

Segundo Raichelis a fragmentação e a setorização interfere na efetividade das políticas públicas e seus impactos na melhoria das condições de vida da população. Reflete também nos Conselhos que foram criados no âmbito das políticas sociais públicas setoriais, cada um deles voltados para ações específicas no seu campo de intervenção. Neste sentido:

"A multiplicação acelerada dos conselhos, a dinâmica própria de funcionamento de cada um e o envolvimento com pautas específicas contribuem, mesmo que voluntariamente, para manter a fragmentação e a segmentação das políticas públicas, dificultando, em última instância, o enfrentamento da lógica que estrutura a ação estatal e a capacidade de produzir respostas satisfatórias em cada uma de suas áreas." 51

A fragmentação da Política de Proteção aos Direitos da Criança e do Adolescente também reflete em seu controle social. No Distrito Federal esta política é executada, basicamente, pela Secretaria de Ação Social e a Secretaria de Justiça e de Direitos Humanos, e não só a execução é setorizada, também o controle social mantém esta tendência de trabalho fragmentado, sem qualquer articulação. ${ }^{52}$

Neste sentido observa-se que apesar da implementação dos Conselhos terem avançado nos últimos anos ainda há uma série de limitações para seu progresso, segundo menciona a assistente social do Conselho de Assistência Social do Distrito Federal - CAS/DF durante a entrevista.

O primeiro é o ambiente jurídico ou normativo, que inclui as leis municipais e outras regulações, como regimento interno e manuais de procedimentos. O segundo é relativo à

\footnotetext{
${ }^{50}$ Ainda a questão social, expressão multifacetada de conflitos e problemas decorrentes das lutas pela apropriação da riqueza social, tende segundo Raichelis a ser restrita aos objetos de cada uma das políticas setoriais, "dificultando a formulação de análises e propostas de intervenção que considerem a realidade social como uma totalidade complexa, dinâmica, conflituosa".

${ }^{51}$ RAICHELIS, Raquel, A Articulação entre os conselhos de políticas públicas: uma pauta a ser enfrentada pela sociedade civil. Diponível em: <http//Www.abong.org.br/novosite/download/4_raquel.pdf.

${ }^{52}$ A Política de Proteção aos Direitos da Criança e do Adolescente é transversal e abrange outras áreas além da Assistência Social, como por exemplo, a Saúde. Mas neste trabalho versa apenas à área de Direitos Humanos e Assistência Social, por entender que estas políticas contêm maior impacto na proteção da criança e do adolescente.
} 
estrutura física humana: carro, telefone, internet, pessoal administrativo e técnico. Mais subjetivos, idade, instrução profissão, motivações à candidatura e a própria formação pessoal do conselheiro também, podem ser limitadoras ou potencializadoras. Em seguida vêm as demandas, as ações e as atribuições. Por último, as suas relações: como o conselho interage com a criança, o adolescente e a família, com a comunidade e a sociedade em geral, com as esferas de governo, com o Ministério Público e com a mídia. Segundo o André Kaminski "precisamos trabalhar todos esses ambientes potencialmente limitadores para poder avançar mais". ${ }^{53}$

É nesse contexto que se impõe a necessidade de discutir os mecanismos de articulação entre os Conselhos de Direitos visando reduzir e amenizar os aspectos limitadores na defesa dos direitos e das políticas sociais.

Conforme a Raichelis a articulação entre os diferentes Conselhos de Direitos é um desafio que deve ser enfrentado em razão da natureza transversal das várias políticas sociais, verbis:

"O enfrentamento desse desafio é ainda mais relevante se considerarmos a natureza transversal a várias políticas sociais de áreas como a da criança e do adolescente, sendo absolutamente insuficientes seu planejamento e sua gestão de forma isolada do conjunto das ações sociais públicas. Outras, como a assistência social, além do esforço para se constituir como política específica tem como vocação viabilizar a relação orgânica de um conjunto de políticas sociais, tensionando-as no sentido de incluir novos sujeitos demandantes de serviços e direitos, historicamente excluídos de seu alcance.

Mas para que essas possibilidades se concretizem, é fundamental que a perspectiva de interface entre as políticas sociais seja assumida pelos gestores governamentais nas três esferas de poder como uma prioridade de seus planos de ação. É preciso decisão política do Executivo para a criação de instâncias organizativas que viabilizem a gestão intersetorial democrática e participativa, de forma a dar suporte às ações integradas entre programas e projetos sociais a serem priorizados, incluindo necessariamente o planejamento e a alocação de recursos orçamentários para tal finalidade."

Verifica-se que os Conselhos de Direitos em ações pontuais contam com a articulação entre os diversos âmbitos da política social como um instrumento de gestão e de garantia de participação democrática, contudo é necessário pensar alternativas sistemáticas e contínuas de

\footnotetext{
53 Apud. Apud. VIVARTA, Veet (coord). Ouvindo Conselhos: democracia participativa e direitos da infância na pauta das redações brasileiras. São Paulo: Cortez, 2005.
} 
interação e para isto o fortalecimento da participação da sociedade civil nos Conselhos se mostra fundamental. Neste sentido:

"Mas para disputar criativamente o sentido e a direção das políticas sociais e democratizar a gestão pública, a articulação entre os conselhos, nas três esferas governamentais, é tarefa fundamental. E os desafios são grandes! Apesar de algumas iniciativas relevantes, é preciso viabilizar caminhos e alternativas que não sejam pontuais e esporádicos, mas que construam efetivamente uma agenda de articulação. Para isso, o papel das organizações e movimentos que compõem a representação da sociedade civil nos conselhos é crucial". 54

A atuação das diversas forças de poder que compõem a gestão e a formulação de políticas públicas para a criança e o adolescente deve ser direcionada para o fortalecimento de alianças entre entidades, organizações não-governamentais e movimentos sociais para que os conselhos possam transcender seus limites, "por vezes estreitos e corporativistas, de suas pautas específicas, avançando na identificação das interfaces e das possibilidades de constituição de agendas comuns". 55

Este esforço deve ser no sentido de promover a discussão da política de defesa da criança e do adolescente nos espaços coletivos, e criar canais e veículos de informação integrados pelos vários conselhos, e não reforçar a visão setorizada e fragmentada das políticas sociais.

Como visto os Conselhos de Direitos são órgãos que exercem uma função pública e como tal devem seguir os princípios da administração pública, dentre eles destaca-se o da publicidade, sendo fundamental para os conselhos se consolidarem como espaços públicos democráticos a visibilidade pública. De acordo com Raichelis a transparência e a informação entre os Conselhos precisam ser intensificadas, verbis:

"Isso significa que as ações, os discursos e os critérios que orientam as deliberações dos conselhos devem-se expressar com fidedignidade e publicidade, não apenas para os diretamente envolvidos, mas para todos os que serão implicados pelas decisões assumidas. Para isso, a transparência e a circulação das informações interconselhos precisam ser intensificadas, para que seu acesso seja

${ }^{54}$ RAICHELIS, Raquel, A Articulação entre os conselhos de políticas públicas: uma pauta a ser enfrentada pela sociedade civil. Diponível em: <http//WWW.abong.org.br/novosite/download/4 raquel.pdf.

${ }^{55}$ Ibidem. 
cada vez mais amplo e contribua para uma visão de totalidade da política social que está sendo implementada”. 56

Contudo, identifica Raichelis que há significativa unanimidade nos estudos e avaliações da experiência dos Conselhos quanto à frágil representação da sociedade civil. Assim, a luta pela ampliação de direitos sociais "está diretamente relacionada à ampliação de espaços públicos". 57

Verifica-se, portanto, que a dinâmica de funcionamento dos Conselhos deve ser repensada e reavaliada para que não se reflita na precariedade da participação da sociedade civil a exclusão destes novos atores sociais da esfera decisória das políticas sociais.

Outra questão relevante relaciona-se às demandas de capacitação dos conselheiros. De acordo com Raichelis é importante para a existência da articulação entre os diversos Conselhos de Direitos uma capacitação conjunta:

"Para a articulação dos conselhos, também é fundamental incluir nos projetos de capacitação dos conselheiros a demanda de formação conjunta dos vários conselhos, para que, sem diluir as questões específicas, possam desenvolver conteúdos voltados para temáticas gerais, que garantam a análise crítica sobre os mecanismos de formulação e gestão da coisa pública, bem como sobre o funcionamento dos diversos aparelhos e instâncias que compõem o Estado em seus vários níveis de poder. Ao mesmo tempo, o fortalecimento de atores coletivos poderia ser mais explorado por diferentes formatos de capacitação direcionados à criação de vínculos mais estreitos com outros atores coletivos, por intermédio de organizações e movimentos sociais nos quais se inserem, do que com atores individuais." 58

Sendo a intersetorialidade e de articulação entre as políticas sociais uma questão estratégica. Raichelis destaca ainda necessidade de criar 'instâncias responsáveis por relações

\footnotetext{
${ }^{56}$ RAICHELIS, Raquel, A Articulação entre os conselhos de políticas públicas: uma pauta a ser enfrentada pela sociedade civil. Diponível em: <http//Www.abong.org.br/novosite/download/4_raquel.pdf.

57 Ibidem.

${ }^{58}$ RAICHELIS, Raquel, A Articulação entre os conselhos de políticas públicas: uma pauta a ser enfrentada pela sociedade civil. Diponível em: <http//Www.abong.org.br/novosite/download/4 raquel.pdf.
} 
intersetoriais e interdisciplinares que garantam a integração entre setores e níveis decisórios, assim como o monitoramento e a avaliação dos resultados". 59

Conforme entrevistas realizadas no Conselho de Assistência Social do Distrito Federal - CAS/DF e no Conselho de Direitos da Criança e do Adolescente - CDCA/DF, verifica-se que não existem ações comuns, cada órgão exerce sua atividade independente do outro. Esta idéia é reforçada pelo fato da Política de Proteção aos Direitos da Criança e do Adolescente ser executada, basicamente, por dois órgãos distintos.

A fragmentação das políticas sociais conduziu a fragmentação do controle social, onde CDCA/DF atua no acompanhamento, fiscalização e controle da política executada pela Secretaria de Justiça e de Direitos Humanos, que prioriza a questão das crianças e adolescentes em conflito com a lei, abuso sexual de crianças e adolescentes ameaçadas de morte, enquanto o CAS/DF atua no acompanhamento, fiscalização e controle da política executada pela Secretaria de Ação Social, priorizando o atendimento sócio educativo, erradicação do trabalho infantil, geração e transferência de renda.

Contudo pode-se extrair da análise documental e da entrevista realizadas nos Conselhos que tanto o CDCA/DF e o CAS/DF atuam na fiscalização das entidades que prestam atendimento à criança e adolescente, como por exemplo, os abrigos. Mas mesmo exercendo atividades comuns estes Conselhos não mantêm qualquer relação, nem mesmo de troca de informação, o que reforça a fragmentação e a fragilidade das políticas.

Nesta articulação com os diversos órgãos responsáveis pelas políticas sociais os Conselhos de Direitos devem assumir a responsabilidade de promover o debate intersetorial entre as diferentes esferas de poder, podendo conforme expõe Raichelis "contar com assessoria externa para

\footnotetext{
${ }^{59}$ RAICHELIS, Raquel. A Articulação entre os conselhos de políticas públicas: uma pauta a ser enfrentada pela sociedade civil. Diponível em: 〈http//WwW.abong.org.br/novosite/download/4 raquel.pdf.y. Acesso em 14 mai.2007.
} 
propor ações em rede que diminuam o paralelismo e permitam ocupar os vazios de atendimento em múltiplos campos e temáticas". 60

Neste sentido vale citar ainda uma experiência interessante e importante para o fortalecimento do controle social como mecanismo de participação social, que é a Casa de Conselhos. Este é um projeto da Prefeitura Municipal de Araraquara/SP, que tem por objetivo fortalecer a participação popular para o exercício pleno do controle social, com participação popular e inclusão social. A Casa de Conselhos consiste em uma congregação dos órgãos colegiados do Município de Araraquara, em um espaço púbico, que acolhe os conselheiros para oferecer assessoria, capacitação, articulação e consulta sobre as atividades de todos os Conselhos Municipais. Dentre as várias ações executadas destaca-se a criação de um "Fórum Interconselhos" que seria a instância responsável pela articulação entre os vários Conselhos. ${ }^{61}$

No Distrito Federal com a posse do novo Governador em 2007, todos os Conselhos de Direitos, foram colocados no mesmo prédio, o que deveria facilitar o convívio e a interação entre estes órgãos. Porém, o que se pode perceber durante a entrevista realizada dos Conselhos é que cada órgão exerce sua atividade independente do outro.

Pode-se verificar pelo trabalho que os Conselhos ainda estão inseridos na racionalidade setorizada e fragmentada da Política de Proteção à Criança e ao Adolescente, proposta pelos ideais neoliberais. Contudo a responsabilidade pelo fortalecimento da Política de Proteção aos Direitos da Criança e do Adolescente no Distrito Federal é de responsabilidade do Conselho dos Direitos da Criança e do Adolescente do Distrito Federal - CDCA/DF e o Conselho de Assistência Social do Distrito Federal - CAS/DF, que devem promover o debate intersetorial construindo uma agenda conjunta, sistemática e contínua.

\footnotetext{
${ }^{60}$ Apud. VIVARTA, Veet (coord). Ouvindo Conselhos: democracia participativa e direitos da infância na pauta das redações brasileiras. São Paulo: Cortez, 2005.

${ }^{61}$ Esta informação foi retirada do site www.araraquara.sp.gov.br. Destaca-se ainda que esta iniciativa é observada em outros Municípios do estado de São Paulo como Campinas, Guarulhos e no estado do Paraná no Município de Irati.
} 


\section{CONSIDERAÇÕES FINAIS}

Este trabalho tratou da necessidade de articulação entre o Conselho de Assistência Social do Distrito Federal - CAS/DF e o Conselho dos Direitos da Criança e do Adolescente do Distrito Federal - CDCA/DF, para a proteção dos direitos da criança e do adolescente.

Como vimos a Política de Proteção aos Direitos da Criança e do Adolescente sempre esteve relacionada com a Política de Assistência Social, um exemplo é o fato do primeiro Código de Menores de 1927 ser a consolidação das leis de assistência voltadas para a infância. Podemos perceber também como ocorreu a evolução do tema infância e adolescência, que em um primeiro momento era caracterizado pela filantropia e a caridade, num segundo pela consolidação do sistema jurídico-adiminstrativo e no terceiro pelo reconhecimento da criança e do adolescente como sujeito de direitos.

A partir da instituição do Estado Democrático de Direito foram criados instrumentos de participação popular no processo decisório, dentre eles destaca-se os Conselhos de Direitos um dos executores do controle social, por serem órgãos integrantes do sistema descentralizado, cuja competência é formular, fiscalizar e avaliar as políticas públicas.

A institucionalização destes mecanismos de participação da sociedade civil na gestão pública surgiu em um momento caracterizado pela privatização do público, sob a égide dos ideais neoliberais, que acarretou a fragmentação das políticas sociais.

No Distrito Federal a Política de Proteção aos Direitos da Criança e do Adolescente seguem esta mesma lógica de fragmentação e setorização das políticas sociais, uma vez que a esta é executada pela Secretaria de Justiça e Direitos Humanos, quanto à questão do adolescente em conflito com a lei, abuso sexual de crianças e adolescentes, e crianças e adolescentes ameaçados de morte; e pela Secretaria de Ação Social quanto ao atendimento sócio educativo, erradicação do trabalho infantil, e a transferência de renda.

O Controle Social exercido pelo Conselho da Assistência Social - CAS/DF, e pelo Conselho dos Direitos da Criança e do Adolescente - CDCA/DF, tem ações comuns como, por exemplo, a fiscalização dos abrigos e de entidades que prestam atendimento sócio educativo às 
crianças e adolescentes. Entretanto seguem a mesma lógica da setorização, e não mantém qualquer interação, conforme entrevista realizada nos Conselhos.

Durante a entrevista pude perceber que o Conselho de Assistência Social do Distrito Federal - CAS/DF entende que a falta de comunicação é um limitador, porque muitas vezes há entidades de assistência social que são denunciadas por maus tratos ou tratamento inadequado às crianças perante o Conselho de Direitos da Criança e do Adolescente do Distrito Federal CDCA/DF que não chegam ao conhecimento do CAS/DF, o que dificulta a apuração dos fatos durante a fiscalização.

Quanto ao Conselho de Direitos da Criança e do Adolescente do Distrito Federal CDCA/DF esta não é uma preocupação marcante, pude verificar que este Conselho está mais preocupado em a questão da capacitação dos Conselheiros para a análise do orçamento e gerenciamento do Fundo da Criança e do Adolescente. Tendo a falta de capacitação também se apresentado como um limitador para o CAS/DF.

Logo podemos afirmar que os problemas enfrentados pelo Conselho de Assistência Social do Distrito Federal - CAS/DF são os mesmos enfrentados pelo Conselho de Direitos da Criança e do Adolescente do Distrito Federal - CDCA/DF, ou seja, recursos humanos e materiais, fragilidade na participação da sociedade civil, falta de capacitação dos conselheiros, necessidade de fortalecimento do órgão. Assim, percebemos a necessidade de articulação entre os Conselhos de Direitos a fim de amenizar e buscar soluções conjuntas para estes problemas.

Pode-se afirmar que os Conselhos de Direitos estão inseridos na racionalidade setorizada e fragmentada das Políticas Sociais. Contudo cabe ao Conselho dos Direitos da Criança e do Adolescente do Distrito Federal - CDCA/DF e ao Conselho de Assistência Social do Distrito Federal - CAS/DF, promover o debate intersetorial construindo uma agenda de ações conjuntas, sistemáticas e contínuas.

Assim hipótese da pesquisa de que o Conselho de Assistência Social do Distrito Federal - CAS/DF e o Conselho de Direitos da Criança e do Adolescente - CDCA/DF ainda não se 
articulam e isto fragiliza a Política de Proteção aos Direitos da Criança e do Adolescente foi confirmada.

Os objetivos específicos da pesquisa foram alcançados, pois foi possível compreender a Política de Proteção aos Direitos da Criança e do Adolescente, por meio de uma análise comparativa da legislação e do processo histórico da criança e do adolescente; entender como são executadas as ações de proteção à criança e ao adolescente atualmente, e em que lógica estão inseridas; analisar a natureza, composição e função dos Conselhos de Direitos; e buscar justificativa teórica política e teórica para a necessidade da articulação entre os Conselhos de Direitos no aperfeiçoamento do controle social.

Deste modo o objetivo geral da pesquisa foi cumprido na medida em que foi encontrada uma justificativa política e teórica para a necessidade de articulação entre os Conselhos de Direitos que acompanham, fiscalizam e controlam a Política de Proteção aos Direitos da Criança e do Adolescente visando o aperfeiçoamento dos mecanismos de controle social foi encontrada. 


\section{BIBLIOGRAFIA}

- ASSOCIAÇÃO BRASILEIRA DE NORMAS TÉCNICAS. NBR 6023: informação e documentação: referências - elaboração. Rio de Janeiro, 2000.

- CENTRO UNIVERSITÁRIO DE BRASÍLIA. Faculdade de Ciências Jurídicas e Sociais. Curso de Direito. Manual de Elaboração de Monografias. Brasília, 2002.

- DECRETO nº 17.943-A, de 12 de outubro de 1927. Dispõe sobre o Código de Menores

- DIDONET, Vital. Representação da Criança na Sociedade Brasileira. Infância e Desenvolvimento: Desafios e Propostas, Organizadores Antônio Rocha Magalhães e Walter Garcia, Brasília: IPEA, Série IPEA; n.140, 1993.

- DISTRITO FEDERAL. Resolução nº12, de 6 de agosto de 2002. Dispõe sobre o Regimento Interno do Conselho de Assistência Social do Distrito Federal - CAS/DF.

- FALEIROS. Vicente de Paulo. Uma Década de Direitos: Avaliação dos dez anos de Estatuto da Criança e do Adolescente. Série Escola de Conselhos. Cadernos para a Cidadania. Brasília: CECRIA, 2000.

- INSTITUTO INTERAMERICANO DEL NIÑO, Editora Universitária Santa Úrsula, AMAIS Livraria e Editora. A Arte de Governar Crianças: A História das Políticas Sociais, da Legislação e da Assistência à Infância no Brasil. Rio de Janeiro:1995.

- Internet

- LEI n ${ }^{o}$ 6.697, de 10 de outubro de 1979. Dispõe sobre o Código de Menores.

- MARTINS, Danielle Comim. Estatuto da Criança e do Adolescente e a Política de Atendimento. 1. ed. Curitiba: Juruá, 2004. 
- MERISSE, Antônio; JUSTO, José Sterza; ROCHA, Luiz Carlos et al. Lugares da Infância: reflexões sobre a história da criança na fábrica, creche e orfanato. São Paulo: Arte e Ciência, 1997.

- RAICHELIS, Raquel. A Articulação entre os conselhos de políticas públicas: uma pauta a ser enfrentada pela civil. Disponível em: $<$ http//wwW.abong.org.br/novosite/download/4 raquel.pdf.:. Acesso em 14 mai.2007.

- RAICHELIS, Raquel. Esfera Pública e Conselhos de Assistência Social: caminhos da construção democrática. São Paulo: Cortez, 1998.

- RIZZINI, Irene; RIZZINI, Irmã. A Institucionalização de Crianças no Brasil: percurso histórico e desafios do presente. Editora PUC, Rio de Janeiro: 2002.

- SILVA, José Afonso. Curso de Direito Constitucional Positivo. São Paulo: Malheiros, 2005.

- Site http://www.araraquara.sp.gov.br.

- Site'http://www.mds.gov.brh institucional/

- Site htttp://Wwww.presidencia.gov.br/estrutura presidencia/sedh/,

- VIEIRA, L.M.F. Mal Necessário: Creches no Departamento Nacional da Criança. Caderno de Pesquisa, n.67, p. 3-16, nov. 1988.

- VIVARTA, Veet (coord). Ouvindo Conselhos: democracia participativa e direitos da infância na pauta das redações brasileiras. São Paulo: Cortez, 2005. 


\section{ANEXO \\ ROTEIRO DE ENTREVISTA}

\section{Bloco I - Questões sobre a Instituição}

1) Quando o Conselho foi criado?

2) Houve diferença entre a data de criação e o início de suas atividades?

3) Há Regimento Interno?

4) O Conselho tem orçamento próprio?

5) O Conselho segue o que dispõe os Conselhos Nacionais (CONANDA/CNAS)?

\section{Bloco II - Questões sobre a competência da Instituição}

1) O Conselho tem competência para formular a Política de Proteção aos Direitos da Criança e do Adolescente e/ou de Assistência Social. Qual é a Política de proteção local?

2) Os Conselhos tem como competência promover, apoiar e incentivar a realização de estudos e pesquisa na área da Política. Esta atribuição é realizada? Como?

3) O Conselho a cada dois anos deve convocar a Conferência Distrital para avaliar a Política. Qual o nível de participação das entidades e da sociedade civil nesta Conferência?

4) Quais as limitações para a execução de tais competências (Recursos humanos, materiais, físicos)?

5) Os Conselheiros estão capacitados para deliberar sobre a Política?

\section{Bloco III - Questões sobre o Orçamento}

1) Ainda quanto às competências o Conselho deve assessorar o Poder Executivo na elaboração da proposta orçamentária. O Conselho tem caráter deliberativo no caso do orçamento?

2) Os Conselheiros são competentes para deliberar sobre o orçamento?

3) Para financiar a Política utiliza exclusivamente os recursos do Fundo de Assistência Social e/ou Fundo dos Direitos da Criança e do Adolescente?

4) Os recursos deste fundo são suficientes para financiar a Política? 
This document was created with Win2PDF available at http://www.win2pdf.com.

The unregistered version of Win2PDF is for evaluation or non-commercial use only.

This page will not be added after purchasing Win2PDF. 


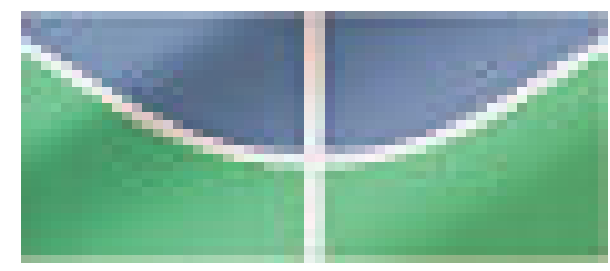

UNIVERSIDADE DE BRASÍLIA INSTITUTO DE CIÊNCIAS HUMANAS DEPARTAMENTO DE SERVIÇO SOCIAL

CONTROLE SOCIAL NA PROTEÇÃO DOS DIREITOS DA CRIANÇA E DO ADOLESCENTE.

TRABAHO DE CONCLUSÃO DE CURSO

Danielle Alves de Brito

Matrícula: 99/55381

Brasília - DF

Junho de 2007 


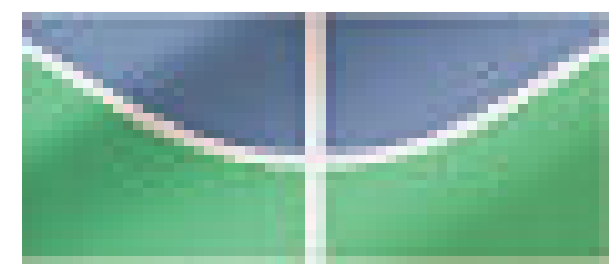

UNIVERSIDADE DE BRASÍLIA INSTITUTO DE CIÊNCIAS HUMANAS DEPARTAMENTO DE SERVIÇO SOCIAL

\section{CONTROLE SOCIAL NA PROTEÇÃO DOS DIREITOS DA CRIANÇA E DO ADOLESCENTE.}

Trabalho de Conclusão de Curso apresentado como requisito para a aquisição do grau de Assistente Social no curso de Serviço Social da Universidade de Brasília - UnB.

Orientadora: Maria Lúcia Pinto Leal 
CONTROLE SOCIAL NA PROTEÇÃO DOS DIREITOS DA CRIANÇA E DO ADOLESCENTE.

Trabalho defendido sob avaliação da Banca Examinadora constituída por:

Prof $^{a}$. Doutora Maria Lúcia Pinto Leal (Orientadora)

Prof. Doutor Mário Ângelo Silva

Universidade de Brasília - UnB

Prof $^{a}$. Mestre Ozanira Ferreira da Costa

Universidade de Brasília - UnB 


\section{AGRADECIMENTOS}

Gostaria de agradecer ao Conselho de Assistência Social do Distrito Federal - CAS/DF e ao Conselho dos Direitos da Criança e do Adolescente do Distrito Federal - CDCA/DF que possibilitaram os estudos de campo, fornecendo profissionais para a entrevista;

à Professora Doutora Maria Lúcia Pinto Leal, pelo conhecimento compartilhado, pelo direcionamento do trabalho, pela paciência e atenção que dedicou a este trabalho;

ao Professor José Airton de Brito, pelas sugestões e críticas apresentadas ao final deste estudo, bem como pelo seu apoio permanente; e

à Professora Fátima Fontenele, cujo apoio e dedicação sempre foram fundamentais, não só para a elaboração deste trabalho, mas durante todo o período de Graduação. 


\section{SUMÁRIO}

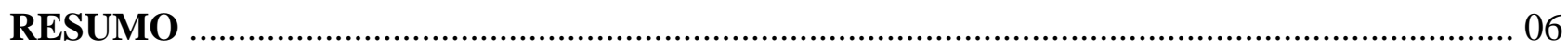

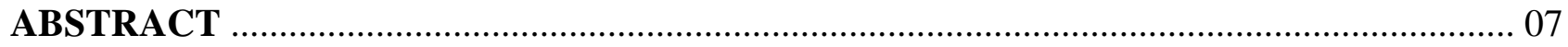

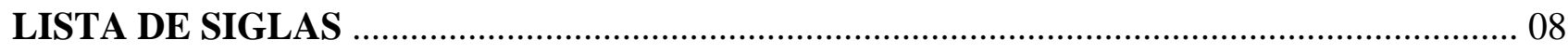

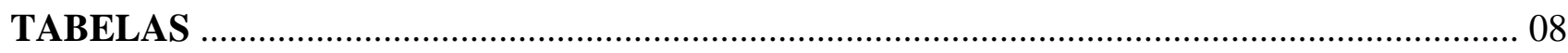

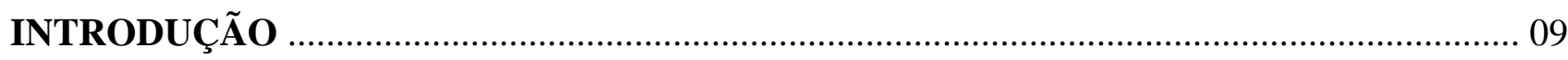

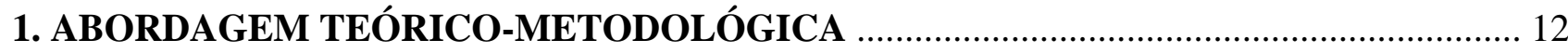

2. CONTROLE SOCIAL NA PROTEÇÃO DOS DIREITOS DA CRIANÇA E DO

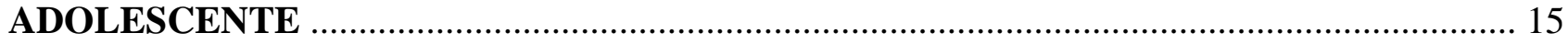

2.1. A Política de Assistência à Infância e Adolescência ..................................................... 15

2.1.1Processo Histórico da Política de Assistência à Infância no Brasil............................ 16

2.2. O Estado Democrático de Direito e a Proteção aos Direitos da Criança e do

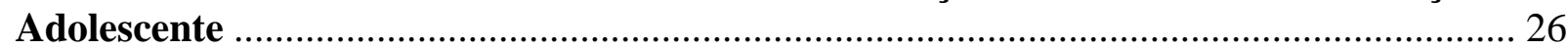

2.2.1. Os Conselhos de Direitos e o Controle Social ...................................................... 30

2.2.1.1. O Conselho de Assistência Social do Distrito Federal - CAS/DF ........... 32

2.2.1.2. O Conselho de Defesa da Criança e do Adolescente do Distrito Federal -

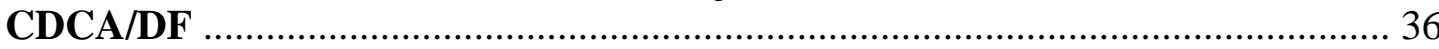

2.3. Articulação entre os Conselhos para a Proteção dos Direitos da Criança e do Adolescente

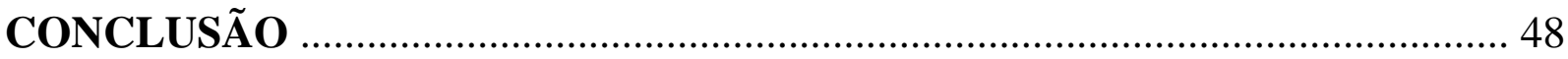

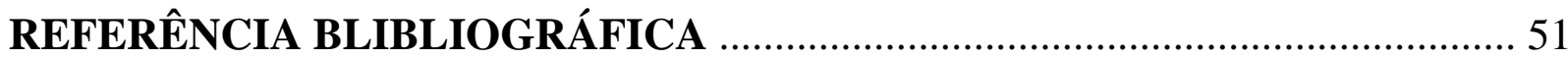

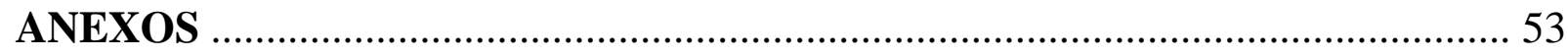




\section{RESUMO}

Esta pesquisa tem por objeto entender o grau de articulação entre o Conselho de Assistência Social do Distrito Federal - CAS/DF e o Conselho dos Direitos da Criança e do Adolescente do Distrito Federal - CDCA/DF, no acompanhamento, controle e fiscalização da Política de Proteção aos Direitos da Criança e do Adolescente no Distrito Federal. A hipótese da pesquisa é de que o Conselho de Assistência Social - CAS/DF e o Conselho de Direitos da Criança e do Adolescente - CDCA/DF não se articulam e isto fragiliza a Política de Proteção aos Direitos da Criança e do Adolescente. O objetivo geral da pesquisa é encontrar uma justificativa política e teórica para a necessidade de articulação entre os Conselhos de Direitos que acompanham, fiscalizam e controlam a Política de Proteção aos Direitos da Criança e do Adolescente visando o aperfeiçoamento dos mecanismos de controle social. A partir da Constituição de 1988 foi instituída a possibilidade de participação popular na gestão das políticas pública. O controle social é um mecanismo democrático de participação popular na formulação, execução e avaliação das políticas sociais. Dentre as formas de execução do controle social destaca-se a atuação dos Conselhos de Direitos. Os Conselhos de Direito são órgãos integrantes do sistema descentralizado com competência normativa, deliberativa e fiscalizadora das políticas públicas. No Distrito Federal a Política de Proteção aos Direitos da Criança e do Adolescente é executada de forma fragmentada e setorizada pela Secretaria de Justiça e de Direitos Humanos e pela Secretaria de Ação Social. O controle social exercido pelo Conselho de Assistência Social do Distrito Federal - CAS/DF e pelo Conselho dos Direitos da Criança e do Adolescente - CDCA/DF também é fragmentado, o que reforça a fragilidade das Políticas Sociais. Defende-se que os Conselhos de Direito devem assumir a responsabilidade promover o debate intersetorial da política de proteção aos diretos da criança e do adolescente de forma a manter a interação e a construção de uma agenda comum entre estes órgãos.

Palavras-chave: Direitos da Criança e do Adolescente. Estado Democrático de Direitos. Sistema Descentralizado. Participação Social. Democracia Direta. Controle Social. Conselhos de Direitos. 


\begin{abstract}
ASBSTRACT
The objective of this research is understand the rate of articulation among the Counsel of Aid Social of the District Federal and the Counsel from the Rights from Child and of the Adolescent of the District Federal, into the accompanying, control and inspection from Policy of Protection to the Rights from Child and of the Adolescent into the District Federal. The assumption from research is of what the Counsel of Aid Social and the Counsel of Rights from Child and of the Adolescent haven't you articulate and this brittleness the policy of Protection to the Rights from Child and of the Adolescent. The purpose across the board from research is meet only one justification policy and abstract for necessity of articulation among the Admonitions of Rights what accompanying, be subject to fiscal controls and control the policy of Protection to the Rights from Child and of the Adolescent aim at the enhancement from the mechanisms of control social. The part from Constitution of 1988 was established the possibility of participation popular on administration from the public policies. The screening social that's a mechanism democratic of participation popular on formulation, execution and assessment from the policies sociais. In the midst of the shapes of execution of the control social highlighted - if the multi-skilled from the Admonitions of Rights. The counsels of Right are agencies integrates of the system uncentered with ability normative, deliberative and inspection from the public policies. Into the District Federal the policy of Protection to the Rights from Child and of the Adolescent is carried out of she forms fragmented \& setorizada by Secretariat of Justice and of Human rights and by Secretariat of Act Social. The screening social exercise at Admonition of Aid Social of the District Federal and at Admonition from the Rights from Child \& of the Adolescent it is also fragmented, the one to reinforced the frailty from the Policies Socials. Defends - if as the Admonitions of Right owes assume the responsibility promote the talk intersetorial from policy of protection to the rights from child and of the adolescent of she forms the maintain the interaction and the construction from a agenda common among these organs.
\end{abstract}

Key Words: Rights from the Child and from the Juvenile. State Democratic as of Rights. System Federative and Uncentered. Participation Social. Democracy. Controls Social. Advice as of Rights. 


\section{LISTA DE SIGLAS}

CAS/DF - Conselho de Assistência Social do Distrito Federal

CDCA/DF - Conselho dos Direitos da Criança e do Adolescente

CNAS - Conselho Nacional de Assistência Social

CONANDA - Conselho Nacional de Direitos da Criança e do Adolescente

ECA - Estatuto da Criança e do Adolescente

FEBEM - Fundação Estadual de Bem-Estar do Menor

FUNABEM - Fundação Nacional de Bem-Estar

LBA - Legião Brasileira de Assistência

LOAS - Lei Orgânica da Assistência Social

MNMMR - Movimento Nacional de Meninos e Meninas de Rua

ONG - Organização Não-Governamental

PNBEM - Política Nacional do Bem-Estar do Menor

SAM - Serviço de Assistência a Menores

SEAS - Secretaria de Assistência Social do Distrito Federal

SUAS - Sistema Único da Assistência Social

UNICEF - Fundo das Nações Unidas para a Infância

\section{TABELAS}

Tabela 1. Como se dá a execução e o controle social da Política de Proteção aos Direitos da Criança e do Adolescente. 


\section{INTRODUÇÃO}

A Constituição de 1988 instituiu uma nova ordem jurídica, política e social, o que implicou na democratização do Estado e na possibilidade de participação da sociedade na gestão pública, por meio da sociedade civil organizada, dos Fóruns, das Conferências e dos Conselhos de Direitos. Dentre estas instâncias de participação popular chama atenção para a atuação dos Conselhos de Direitos no controle social.

O controle social é um mecanismo democrático de participação da sociedade civil na gestão e organização das entidades públicas e privadas. Esta participação é exercida de forma muito peculiar pelos Conselhos de Direito, que são órgãos integrantes do sistema descentralizado com competência normativa, deliberativa e fiscalizadora das políticas públicas.

Os Conselhos de Direitos atuam como mecanismos que possibilitam a democracia direta, tendo sido criados em meados da década de 90. Apesar de recentes estes órgãos desempenham um papel fundamental porque atuam na formulação, no acompanhamento e na avaliação de prioridades para as políticas sociais.

A pesquisa surgiu durante a realização de estágio no Conselho de Assistência Social do Distrito Federal - CAS/DF, durante o ano de 2006. Neste campo tive oportunidade de observar a transversalidade da Política de Assistência Social, que contém diversos programas voltados para a criança e para o adolescente, como por exemplo, o benefício de prestação continuada, atividades complementares, abrigamento e o Programa de Erradicação do Trabalho Infantil - PETI, dentre outros.

Assim como a Política de Assistência Social o controle social também segue esta característica de transversalidade, sendo o Conselho de Assistência Social do Distrito Federal CAS/DF responsável por normatizar, acompanhar e fiscalizar esta Política, que abrange o tema criança e adolescente. Contudo, não mantém qualquer relação com o Conselho dos Direitos da Criança e do Adolescente do Distrito Federal - CDCA/DF. 
Esta falta de articulação entre os Conselhos de Direito traz prejuízos para a Política de Proteção à Criança e ao Adolescente, na medida em que atuam de forma segmentada e individualizada diante do tema criança e adolescente, e seguem a lógica da fragmentação e da setorização das políticas sociais.

Neste sentido pode-se afirmar que a falta de articulação entre o Conselho de Assistência Social do Distrito Federal - CAS/DF e o Conselho dos Direitos da Criança e do Adolescente - CDCA/DF reforça a fragilidade da Política de Proteção aos Direitos da Criança e do Adolescente, que deveria ser entendida como um todo harmônico e interelacionado.

Diante desta realidade a discussão acerca do controle social na proteção dos direitos da criança e do adolescente se torna fundamental para o fortalecimento da política social.

A abordagem teórica metodológica adotada foi de primeiro conhecer a natureza e função da Política de Proteção aos Direitos da Criança e do Adolescente, do Estado Democrático de Direito, do Controle Social e dos Conselhos de Direitos. Entendendo que os Conselhos de Direitos não mantém ações interelacionadas para a proteção dos direitos da criança e do adolescente, buscando o aperfeiçoamento do controle social. Foi utilizado o método dialético onde se visa aperfeiçoar o controle social, levando em conta a falta de articulação entre os Conselhos de Direitos, a fragmentação das Políticas Sociais e a fragilidade da participação da sociedade civil. Tendo sido esta pesquisa dividida em quatro partes.

A primeira parte diz respeito à Política de Assistência à Infância e Adolescência, onde foi abordado o processo histórico da assistência à infância no Brasil, que se dividiu em três momentos: o primeiro se caracterizou pelo predomínio da caridade; o segundo pela consolidação do sistema jurídico-administrativo; e terceiro pelo reconhecimento da criança e do adolescente como sujeito de direitos.

A segunda parte trata do Estado Democrático de Direito e da Proteção aos Direitos da Criança e do Adolescente, mencionando o Sistema de Garantias previsto no Estatuto da Criança e do Adolescente - ECA; a possibilidade de participação social no processo de gestão pública; e a concepção de controle social advinda da Constituição de 1988. 
A terceira parte versa sobre os Conselhos de Direitos e o controle social visando compreender a concepção dos Conselhos de Direitos e a atuação comum do Conselho de Assistência Social do Distrito Federal - CAS/DF e o Conselho dos Direitos da Criança e do Adolescente CDCA/DF na Política de Proteção aos Direitos da Criança e do Adolescente do Distrito Federal.

Por fim a quarta parte menciona a necessidade de articulação entre os Conselhos de Direitos para a Proteção dos Direitos da Criança e do Adolescente, tendo em vista que os Conselhos são canais de participação que precisam ser fortalecidos por meio de ações conjuntas e sistemáticas garantindo a universalização dos direitos e quebrando a lógica de fragmentação das políticas sociais.

Deste modo pretende-se de forma abrangente compreender a sistemática da Política de Proteção aos Direitos da Criança e do Adolescente e do Estado Democrático de Direito para poder analisar a importância dos Conselhos de Direitos no controle social e a necessidade de articulação entre estes órgãos para a proteção integral da criança e do adolescente. 


\section{ABORDAGEM TEÓRICO-METODOLÓGICA}

O objeto da pesquisa é entender o grau de articulação entre o Conselho de Assistência Social do Distrito Federal - CAS/DF e o Conselho dos Direitos da Criança e do Adolescente do Distrito Federal - CDCA/DF, no acompanhamento, controle e fiscalização da Política de Proteção aos Direitos da Criança e do Adolescente no Distrito Federal.

A pesquisa parte da hipótese de que o CAS/DF e o CDCA/DF ainda não se articulam e isto fragiliza a Política de Proteção aos Direitos da Criança e do Adolescente.

O Estado Democrático de Direito instituído pela Constituição de 1988, é aquele cujo direito imantado deve conter valores democráticos, de acordo com o interesse coletivo. $\mathrm{O}$ sistema federativo permite a descentralização das decisões e a repartição de poderes e responsabilidades entre as três esferas de governo.

A democratização do Estado implicou no processo de participação da sociedade na gestão pública, principalmente, com a implementação de Conselhos paritários. Os Conselhos são os órgãos integrantes do sistema descentralizado, de competência normativa, deliberativa e fiscalizadora das políticas sociais, que exercem o controle social. O controle social consiste na participação da sociedade civil, na gestão e organização das entidades publica e privadas.

Atuando na defesa e na proteção dos direitos das crianças e adolescentes do Distrito Federal está o Conselho da Assistência Social do Distrito Federal - CAS/DF e o Conselho dos Direitos da Criança e do Adolescente do Distrito Federal - CDCA/DF.

No Distrito Federal a Política de Proteção aos Direitos da Criança e do Adolescente, bem como seu controle social obedecem à lógica da setorização e da fragmentação, em que estes são tidos como partes separadas, sem comunicação e articulação. Portanto, os Conselhos de Direitos devem promover a discussão da Política de Proteção aos Direitos da Criança e do Adolescente nos espaços públicos, criando veículos de informação integrada entre os vários Conselhos. Neste sentido a articulação entre estes órgãos será um instrumento estratégico para quebrar a lógica fragmentada das Políticas Sociais. 
O objetivo geral desta pesquisa é encontrar uma justificativa política e teórica para a necessidade de articulação entre os Conselhos de Direitos que acompanham, fiscalizam e controlam a Política de Proteção aos Direitos da Criança e do Adolescente visando o aperfeiçoamento dos mecanismos de controle social.

Os objetivos específicos da pesquisa são compreender a Política de Proteção aos Direitos da Criança e do Adolescente, por meio de uma análise comparativa da legislação e do processo histórico da criança e do adolescente; entender como são executadas atualmente as ações de proteção à criança e ao adolescente e em que lógica estão inseridas; analisar a natureza, composição e função dos Conselhos de Direitos; e buscar justificativa teórica política e teórica para a necessidade da articulação entre os Conselhos de Direitos no aperfeiçoamento do controle social.

O método de abordagem utilizado será o dedutivo, que parte de uma idéia geral para a particular, entendendo primeiramente a natureza dos Conselhos de Direitos, do controle social e da Política de Proteção aos Direitos da Criança e do Adolescente para posteriormente analisar a execução desta política e a necessidade de articulação entre os Conselhos de Direitos. Será também utilizado o método empírico-dedutivo que visará responder qual o grau de articulação entre os Conselhos de Direitos e qual a real necessidade desta articulação.

Utilizará ainda o método dialético, onde se procura a análise do problema diante das suas diversas formas, partiremos da análise da atuação dos Conselhos de Direitos para verificar que a articulação destes dois órgãos é importante para a proteção da criança e do adolescente.

Quanto ao método de procedimentos este será o histórico, que estuda a natureza dos institutos e para que foram criados; o comparativo, onde será analisado a competência de cada Conselho de Direito e sua atuação na defesa dos direitos da criança e do adolescente.

As fontes de pesquisa utilizadas foram a doutrina jurídica, artigos literários diversificados que abordaram os diversos aspectos do tema, entrevista, observação e a análise documental. 
As entrevistas foram realizadas em 2007, valendo destacar ainda que, no ano de 2007 assumiu um novo Governo no Distrito Federal, e pode ter ocorrido algumas mudanças organizacionais na estrutura dos Conselhos de Direitos.

A entrevista no Conselho de Assistência Social do Distrito Federal - CAS/DF foi realizada em janeiro de 2007, com a assistente social Socorro Garcia Lopes. A entrevista no Conselho dos Direitos da Criança e do Adolescente do Distrito Federal - CDCA/DF foi realizada em abril de 2007, com a assessora Meire Freitas de Moraes.

A observação de campo foi possível durante todo o ano de 2006, em razão da realização de estágio no Conselho de Assistência Social do Distrito Federal - CAS/DF, onde foi elaborada uma Análise Institucional e um Projeto de Intervenção. Quanto ao Conselho dos Direitos da Criança e do Adolescente do Distrito Federal - CDCA/DF a observação somente pode ser realizada durante a entrevista, onde estive atenta às reações de cada pergunta. Mas como o objeto deste trabalho é a necessidade de articulação entre os Conselhos de Direitos, acredito que a observação de campo realizada no CAS/DF foi suficiente.

Também foram analisadas as Leis de criação destes Conselhos de Direitos, Regimentos Internos, Lei Orgânica da Assistência Social - LOAS, Estatuto da Criança e do Adolescente - ECA, Regulamentos do CONANDA e do CNAS, dentre outros documentos disponibilizados pelo CAS/DF e pelo CDCA/DF. 


\title{
2. CONTROLE SOCIAL NA PROTEÇÃO DOS DIREITOS DA CRIANÇA E DO ADOLESCENTE
}

\begin{abstract}
A Constituição Federal de 1988 foi instituída em um período de redemocratização do país e como tal significou uma grande mudança política, social e ideológica. Esta norma permitiu a ampliação dos espaços de atuação da sociedade civil, como a possibilidade da criação de Conselhos de Direitos, que seriam órgãos do sistema descentralizado e participativo, objetivando o controle social nas políticas públicas.
\end{abstract}

O controle social é um mecanismo da democracia direta que permite a participação da sociedade civil na formulação e avaliação das políticas públicas. Além da Sociedade Civil organizada, os Fóruns, Conferências e Comitês, os Conselhos de Direitos também exercem o controle social das políticas públicas. Em razão do processo de fragmentação e de setorização das políticas sociais há diversos Conselhos de Direitos para cada área da política social.

Este trabalho tratará da Política de Proteção aos Direitos da Criança e do Adolescente no Distrito Federal, e de seu controle social, no tocante à atuação do Conselho de Assistência Social do Distrito Federal - CAS/DF e do Conselho dos Direitos da Criança e do Adolescente - CDCA/DF, daí a necessidade de articulação entre estes dois órgãos para que esta Política seja melhor efetivada.

Mas, antes de tratar especificamente deste tema, faz-se necessário comentar a Política de Proteção à Infância e Adolescência.

\subsection{A Política de Assistência à Infância e Adolescência}

A Política de Proteção aos direitos da criança e do adolescente mantém estreito relacionamento com as políticas sociais, especialmente com a Política de Assistência Social. Portanto, para entender melhor a política de assistência à criança e ao adolescente faz-se necessário conhecer seu processo histórico. 


\subsubsection{Processo Histórico da Política de Assistência à Infância no Brasil}

A análise histórica da infância passa pela análise de instituições, sejam elas a família, escola, fábrica, creches, abrigos, centros de internação, dentre outros. A família, como é conhecida hoje, surgiu na Idade Média, se consolidando na ordem capitalista. Mas esta instituição sempre existiu, sendo o primeiro núcleo social com o qual o homem toma contato.

Os laços familiares entre os pais e as crianças neste período não eram eternos, só permaneciam enquanto houvesse a necessidade da sobrevivência, superado este período os filhos saiam desta relação e os pais não tinham mais a obrigação da relação. ${ }^{1}$

Ainda na antiguidade os babilônicos seguiam os dispositivos do Código de Hamurabi, onde o tratamento dado às crianças era rígido se elas infringissem a lei, mas pouco se sabe das relações familiares desta sociedade.

Na família romana o vínculo existente nas relações familiares era pela submissão à pátria potestas, que era uma espécie de chefe e detinha o poder de punir e responsabilizar os membros por atos ilícitos. Neste período a criança era conferida o status de coisa, pois eram tratados como propriedade dos pais.

Com os germanos nos fins do Século V d.C., no entanto, a estrutura familiar foi transformada e, na Idade Média um novo tipo de relação familiar se formou, onde os próprios filhos enquanto crianças, foram os agentes de toda a transformação. Neste sentido vale citar a autora Daniele Comim Martins:

"Durante muito tempo a criança não era tida como importante dentro da "família" medieval. Eram freqüentes as mortes de crianças, que criavam uma indiferença dos pais em relação ao fato. $\mathrm{O}$ tratamento dispensado às crianças era mais semelhante ao dado a um animalzinho doméstico do que ao dado a uma pessoa somente

\footnotetext{
${ }^{1}$ Mas ainda ocorriam famílias que mantinham os laços familiares unidos, contudo a permanência na família decorria da vontade de seus membros e não dos fenômenos naturais.
} 
quando o adolescente se tornava de fato adulto é que ele passava a assumir um papel dentro da família."2

As transformações sobre a família iniciaram nos fins da Idade Média, mas foi a redefinição da cidade, como urbe capitalista, que a família definiu seu caráter privado. Segundo Áries a família moderna restringe aos pais e filhos e passou a ter uma identidade e a ser responsabilizada pelo sucesso ou fracasso futuro de suas crianças. ${ }^{3}$

O período colonial no Brasil foi marcado pelo pouco desenvolvimento urbano. $\mathrm{O}$ final do século XVIII e início do século XIX foram marcados pela Independência do Brasil. Assim até o início do século XX, as iniciativas de atendimento à infância pobre, em sua maioria, ficaram a cargo de ações de caráter familiar e particular e religioso.

Mesmo o atendimento à criança pobre tendo características privadas e religiosas as Casas de Expostos, conhecidas como Casas da Roda ${ }^{4}$ eram uma forma típica de atendimento nos séculos XVIII e XIX, que tinham como propósito maior a proteção aos padrões de moral pública e familiar da época. Acolhiam, no anonimato, filhos de "mães solteiras", de "mulheres de má conduta", crianças abandonadas pelos pais devido à extrema pobreza, filhos de escravos, entre outros enjeitados. ${ }^{5}$ A Roda somente é desativada em 1938, quando a criança pobre deixa de ser objeto apenas da "caridade" e passa a ser objeto de políticas do Estado.

Segundo Rizzini nesta época o Estado se preocupava com a assistência à infância sob a égide dos ideais higienistas e afirma que "muitas rodas de expostos surgiram no Brasil, quando

\footnotetext{
${ }^{2}$ MARTINS, Danielle Comim. Estatuto da Criança e do Adolescente e a Política de Atendimento. 1. ed. Curitiba: Juruá, 2004.

3 Apud MARTINS, Danielle Comim. Estatuto da Criança e do Adolescente e a Política de Atendimento. 1. ed. Curitiba: Juruá, 2004.

${ }^{4}$ A Roda era um dispositivo aberto do lado da rua ligado à instituição religiosa, onde se colocavam crianças recémnascidas e enjeitadas e que girava para dentro da casa, onde a criança era recolhida, cuidada e educada sem o mínimo risco de identificação.

${ }^{5}$ DIDONET, Vital. Representação da Criança na Sociedade Brasileira. Infância e Desenvolvimento: Desafios e Propostas, Organizadores Antônio Rocha Magalhães e Walter Garcia, Brasília: IPEA, Série IPEA; n.140, 1993.
} 
a Europa estava sendo combatida pelos higienistas e reformadores, pela alta mortalidade e pela suspeita de fomentar o abandono de crianças". 6

No início do século XIX fatores como a imigração, a abolição da escravatura, a construção de ferrovias, melhoramentos urbanos e o início da industrialização trazem transformações na estrutura econômica e social do país. Neste momento uma ordem urbanística foi criada, modificando o espaço familiar, onde a "arquitetura e o isolamento fez parte da redefinição do espaço público e privado" 7 , com o modelo burguês de habitação. Momento este exposto pela autora Daniele Comim na seguinte passagem de sua obra:

"Nessa reestruturação da ordem urbana, diferentemente do que ocorreu na Europa no início da Idade Média, quando a família se recolheu espontaneamente em suas casas, dando origem a nossa "família" tal como a conhecemos, a família brasileira foi arrancada do meio público em que vivia e se socializava e foi abandonada e sim mesma, substituindo por si própria as funções que eram assumidas na rua pela sociedade então."8

Com o desenvolvimento urbano e a criação do Estado Nacional Brasileiro, o atendimento médico à família começou a ser difundido em todas as classes sociais "como mecanismo regulador e de controle, capaz de estimular, incentivar ou criar sentimentos na população até então inexistentes ou imperceptíveis, adaptando os indivíduos à ordem do poder". 9 A utilização da prática médica e assistencial utilizada neste período como mecanismo de controle social foram denominadas de Propostas Higienistas.

Em razão da ampliação do controle médico sobre a criação dos filhos das famílias pobres, as propostas higienistas assumiram "diversos tons retóricos, ora assistencialistas, ora sanitaristas, ora medidos, ora morais, prescrevendo regras de conduta pessoal e social" vigiando,

${ }^{6}$ RIZZINI, Irene; RIZZINI, Irmã. A Institucionalização de Crianças no Brasil: percurso histórico e desafios do presente. Editora PUC, Rio de Janeiro: 2002.

${ }^{7}$ MARTINS, Danielle Comim. Estatuto da Criança e do Adolescente e a Política de Atendimento. 1. ed. Curitiba: Juruá, 2004

${ }^{8}$ Ibidem.

${ }^{9}$ Ibidem. 
inclusive, pelo seu cumprimento. ${ }^{10}$ Segundo Franco Vaz a ideologia higienista tem características partenalistas, defendendo a intervenção mínima do Estado diante do problema da criança desvalida. $^{11}$

Neste período o espaço da família é redefinido pela nova ordem, também a criança e o jovem passam a ocupar novos espaços, além da família, como a escola onde seriam reproduzidas relações sociais existentes no espaço público. A partir da iniciativa e da pressão dos higienistas, foram sendo constituídas desde o Império articulações entre público e privado, culminando na fundação de obras filantrópicas.

É a partir do século XX que as iniciativas do Estado de proteção ao menor ganham relevância e são fundamentais para a edição do Código de Menores em 1927, que foi encarregada de enfrentar tanto a problemática dos atos antijurídicos realizados por crianças, como a derivada do abandono e da desproteção familiar, situações qualificadas como "irregulares".

O Código de Menores, estabelecido pelo Decreto n $17.943-\mathrm{A}$, de 12 de outubro de 1927, consolida as leis de assistência de proteção a menores, especialmente focalizada nos delinqüentes e abandonados. Sendo as políticas para a infância voltada para aqueles que estavam sem família, considerados coitadinhos e para os que ameaçavam a ordem pública.

Por sua vez, o Estado, sob o ideais das propostas higienistas, intervinha junto á criança para estabelecer a vigilância da autoridade pública, sobrepondo-se à família para garantir a higiene e a raça, por meio do Programa de Controle de Lactação e da Alimentação para inspeção das pessoas que tivessem crianças pequenas sob sua guarda, podendo a autoridade pública impedir o abrigo em casas consideradas perigosas, anti-higiênicas ou imorais. ${ }^{12}$

${ }^{10}$ VIEIRA, L.M.F. Mal Necessário: Creches no Departamento Nacional da Criança. Caderno de Pesquisa, n.67, p. 3-16, nov. 1988.

${ }^{11}$ Apud. INSTITUTO INTERAMERICANO DEL NIÑO. A Arte de Governar Crianças: A História das Políticas Sociais, da Legislação e da Assistência à Infância no Brasil. Rio de Janeiro: Editora Universitária Santa Úrsula, AMAIS Livraria e Editora, 1995.

${ }^{12}$ FALEIROS. Vicente de Paulo. Uma Década de Direitos: Avaliação dos dez anos de Estatuto da Criança e do Adolescente. Série Escola de Conselhos. Cadernos para a Cidadania. Brasília: CECRIA, 2000. 
O Código de Menores trouxe as seguintes classificações à criança: os abandonados que não tinham habitação certa, nem responsáveis, com famílias consideradas imorais, ou abusivas pela crueldade, negligência ou exploração e que tivessem situações de perigo. Os vadios eram os rebeldes que vivem na casa dos pais, tutor, ou guarda, porém, eram encontrados habitualmente a vagar pelas ruas e logradouros públicos. Os mendigos eram os que habitualmente pediam esmolas. Os libertinos eram aqueles que praticavam atos obscenos, prostitutos ou que viviam da prostituição de outro. ${ }^{13}$

A referente legislação caracterizou-se principalmente pelo controle da infância abandonada e delinqüente, por meio da garantia da ordem moral; manteve a visão higienista e repressora; facilitou a inserção da criança no trabalho; previu a utilização do abrigamento e o internamento como forma de correção; a criança era vista como incapaz e perversa; o poder absoluto era do Estado sobre a família e a criança; a implementação do menorismo como garantia de medidas especiais para os menores de 18 anos; e o estimulo ao trabalho e combate ao vício como forma de reabilitação. $^{14}$

Pode-se afirmar que esta representou um avanço à medida que dava à criança a possibilidade de ser objeto de políticas públicas, ao invés da caridade; aboliu o Sistema de Rodas, mas manteve o princípio de preservar o sigilo sobre a origem da criança.

Como havia possibilidade de trabalho para as crianças no Código de Menores a relação que as crianças tinham com o trabalho era de exploração, uma vez que a mão de obra infantil é usada de forma abundante na indústria e o salário das crianças e adolescentes representa um complemento para os baixos rendimentos das famílias operárias. ${ }^{15}$

A indústria de tecelagem se interessava bastante pelo trabalho infantil sob o argumento de que a "finura dos dedos das crianças" se adapta melhor ao maquinismo, que é também

${ }^{13}$ DECRETO n ${ }^{\text {17.943-A, de }} 12$ de outubro de 1927. Dispõe sobre o Código de Menores.

${ }^{14}$ Ibidem.

${ }^{15}$ Segundo o livro Lugares da Infância "a mecanização foi uma forma de estabelecer controle sobre os trabalhadores à medida que ela possibilitava, fundamentalmente, duas coisas: a redução do número de empregados e, sobre tudo a substituição dos trabalhadores especializados pela mão-de-obra muito barata, dócil e abundante dos migrantes expulsos do campo, das mulheres que a miséria das famílias operárias empurrava para os empregos e, finalmente, das crianças que podiam ser compradas ou alugadas nos asilos para os pobres". 
mencionada por Marx: "procurava principalmente dedos pequenos e ágeis". ${ }^{16} \mathrm{Na}$ verdade o interesse da indústria pelo trabalho infantil não era somente pelas "finuras dos dedos" mas pela possibilidade de baixar gastos com mão-de-obra e aumentar a jornada de trabalho. Também a situação de miséria em que viviam muitos camponeses contribui para a colocação de crianças no mundo do trabalho. ${ }^{17}$ Vale citar a passagem da obra Lugares da Infância:

“Temos, então, que as fábricas só obtiveram sua viabilidade às custas da escravidão infantil. Não é um passado que recomende boas esperanças futuras. Mas a fábrica não surgiu para multiplicar a produção ou reduzir custos. Se advento marcou uma tentativa de utilização do trabalho cativo em lugares fechados, onde o comando do empregador poderia ficar mais distante de qualquer resistência dos que trabalhavam. A fábrica, assim como a prisão, foi resultado de uma ação política e não tecnológica. Ela criou as condições para o cativeiro de empregados que podiam ser explorados ininterruptamente, ao sabor das possibilidades mecânicas que os recursos hidráulicos e do vapor permitiam. A fábrica é a exploração de todos os recursos, entre eles o homem, levada ao limite em que tudo pode ser totalmente exaurido e transformado em mercadorias lucrativas e dejetos imprestáveis. E como os recursos humanos podiam ser comprados a baixo custo nas workhouses dos pobres, os infelizes com os quais os industriais supriam suas máquinas foram sempre utilizados até o esgotamento total". ${ }^{18}$

Nos anos 30 Getúlio Vargas, cujo governo se caracteriza por um projeto centralizador e intervencionista, institui o Ministério do Trabalho, com o objetivo de intervir na questão social, o amparo e a defesa do proletariado urbano e rural. Este Ministério adota uma política corporativista de harmonização das classes sociais, por meio de regulação do Estado tanto pela Justiça do Trabalho como pelo sindicalismo tutelado, sendo este mais um instrumento assistencial do que reivindicativo. ${ }^{19}$

${ }^{16}$ Apud. FALEIROS. Vicente de Paulo. Uma Década de Direitos: Avaliação dos dez anos de Estatuto da Criança e do Adolescente. Série Escola de Conselhos. Cadernos para a Cidadania. Brasília: CECRIA, 2000.

${ }^{17}$ Neste período não só a indústria defende a presença de crianças pobres no trabalho, mas o Estado também criam Escolas de Aprendizes justificadas pelo desenvolvimento urbano das cidades e pelo discurso de preparar tecnicamente para o trabalho filhos de desfavorecidos.

${ }^{18}$ MERISSE, Antônio; JUSTO, José Sterza; ROCHA, Carlos. et al. Lugares da Infância: reflexões sobre a história da criança na fábrica, creche e orfanato. São Paulo: Arte e Ciência, 1997.

${ }^{19}$ INSTITUTO INTERAMERICADO DEL NIÑO. A Arte de Governar Crianças: A História das Políticas Sociais, da Legislação e da Assistência à Infância no Brasil. Rio de Janeiro: Editora Universitária Santa Úrsula, AMAIS Livraria e Editora, 1995. 
Em 1940, o Decreto-Lei 2.204 prevê diretrizes de proteção à maternidade, à infância e à adolescência e cria o Departamento Nacional da Criança com o objetivo de coordenar todas as atividades dirigidas à infância. ${ }^{20}$ Em 1941 o Decreto Lei $n^{\circ} 3.799$ funda o Serviço de Assistência a Menores (SAM), com atribuição de prestar, em todo o território nacional, amparo social a menores desvalidos e infratores. ${ }^{21}$

Em 1942, surge no cenário nacional a Legião Brasileira de Assistência (LBA), com o objetivo de apoiar as famílias dos soldados que integravam a Força Expedicionária brasileira. "Sua entrada no cenário histórico se dá como a expressão institucional do quadro sócio-político da época, profundamente vinculado aos interesses governamentais, principalmente como instrumento de controle da emergente questão social". ${ }^{22}$

Desde a década de 1950, autoridades públicas, que coordenavam o SAM, propuseram um novo instrumento que culminou no surgimento da Fundação Nacional de Bem-Estar FUNABEM, em 1964. A FUNABEM foi instalada no primeiro ano da ditadura militar, e tinha por objetivo instituir o "anti-SAM", com diretrizes que opunham àquelas criticadas no SAM. Segundo Rizzini:

“As propostas que surgem para a instauração de um novo órgão nacional centramse na autonomia financeira e administrativa da instituição e na rejeição ao 'depósito de menores', nos quais se transformaram os internatos para crianças e adolescentes das camadas populares." 23

A Política Nacional do Bem-Estar do Menor - PNBEM, cujas diretrizes foram propostas pelo Governo de Castelo Branco, foi um instrumento de normatização, mas não tinha como objetivo o reconhecimento de direitos, e sim de planejamento e coordenação da ação

\footnotetext{
${ }^{20}$ A ação do Departamento foi marcante ao longo de décadas seguintes, e ainda está viva a influência de suas "normas" e "preceitos", por meio de publicações de intenso conteúdo médico-sanitarista e de cunho moralizante, sua ação transcende a questão da diminuição da mortalidade infantil.

${ }^{21}$ O SAM teve uma trajetória ineficaz, sua atuação teve caráter policial-punitivo e altamente corrupta, passando assim a suscitar uma reação pública de protesto, sendo decretado sua falência em 1954. Salienta-se ainda que a atuação do Estado em articulação com o setor privado é intensificada, sendo criadas várias instituições e obras sociais.

22 DIDONET, Vital. Representação da Criança na Sociedade Brasileira. Infância e Desenvolvimento: Desafios e Propostas, Organizadores Antônio Rocha Magalhães e Walter Garcia, Brasília: IPEA, Série IPEA; n.140, 1993.

${ }^{23}$ RIZZINI, Irene RIZZINI, Irmã. A Institucionalização de Crianças no Brasil: percurso histórico e desafios do presente. Editora PUC, Rio de Janeiro: 2002.
} 
assistencial à infância. Como uma das estratégias de implementação desta política o Governo Federal estimulava a criação de Fundações Estaduais de Bem-Estar do Menor (FEBEMs).

O período pós-64 introduziu alterações significativas nos padrões de proteção social, pois é neste momento que o Estado implementa algumas políticas sociais. Neste sentido vale mencionar Draibe:

"É esse o momento em que efetivamente se organiza os sistemas nacionais públicos ou estatalmente regulados (saúde, educação, assistência social, previdência, e habitação), abrindo espaço para implementação de políticas de massa, de relativamente ampla cobertura". ${ }^{24}$

A Lei 6.697, de 10 de outubro de 1979, denominada Código de Menores, manteve a ordem jurídica prevista no Código de 1927, uma diferença marcante foi a visão terapêutica ou de tratamento com relação ao infrator, mas com relação ao processo de internamento predominava a visão moralista. O termo "situação irregular" também é marcante nesta legislação, e compreendia a privação de condições de subsistência, de saúde, de instrução, por omissão dos pais ou responsáveis, além da situação de maus-tratos e castigos, de perigo moral, de falta de assistência legal, de desvio de conduta por inadaptação familiar ou comunitária, e autoria de infração penal. ${ }^{25}$

A legislação menorista confirmava e reforçava a concepção de incapacidade das famílias pobres em educar os filhos. Neste sentido vale citar Rizzini:

“O novo Código de Menores, instaurado em 1979, criou a categoria de 'menor em situação de irregular', que, não muito diferente da concepção vigente no antigo Código de 1927, expunha as famílias populares à intervenção do Estado, por sua condição de pobreza". 26

Portanto, esta legislação se caracterizava pela sua visão autoritária da política; pelo poder centralizador do Executivo e do juiz; pela repressão aos marginais, como anti-sociais; pelo

\footnotetext{
24 Apud. DIDONET, Vital. Representação da Criança na Sociedade Brasileira. Infância e Desenvolvimento: Desafios e Propostas, Organizadores Antônio Rocha Magalhães e Walter Garcia, Brasília: IPEA, Série IPEA; n.140, 1993.

${ }^{25}$ LEI 6.697, de 10 de outubro de 1979. Dispõe sobre o Código de Menores.

${ }^{26}$ RIZZINI, Irene; RIZZINI, Irmã. A Institucionalização de Crianças no Brasil: percurso histórico e desafios do presente. Editora PUC, Rio de Janeiro: 2002.
} 
internamento e tratamento dos marginalizados ou periferizados, não integrados; pela visão da família e da criança como responsáveis pelas irregularidades; pelo controle do comportamento anti-social; pelo controle da assistência pela tecnocracia e pelos convênios; pelo arbítrio e arbitrariedade do juiz; pela ausência de direitos do menor na sua defesa; pela prisão cautelar de menores, para apurar infração penal grave; pelo internamento por condições de pobreza; pelo abrigamento de crianças; e pela centralização executiva. ${ }^{27}$

Os amplos poderes mantidos aos magistrados não demoraram a ser questionados e combatidos pelos movimentos sociais, com a transição democrática.

Em 1985 o Governo da chamada Nova República implanta diferentes ações frente a crise, de caráter paliativo e assistencialista, reforçando a estratégia de encaminhamento da criança ao trabalho e de clientelismo. Ao mesmo tempo, observa-se o impulsionamento de projetos alternativos, principalmente com o apoio da Fundação das Nações Unidas para a Infância - UNICEF, a articulação com grande número de entidades não governamentais.

Os projetos se desenvolvem por meio de organizações não governamentais em áreas bastante heterogêneas que enfatizavam ações como cerâmica, formação profissional, venda de produtos, alfabetização, ensino religioso, com forte presença de atores religiosos. A partir da articulação desses projetos surge o Movimento Nacional de Meninos e Meninas de Rua (MNMMR), fundado em 1985, que realiza três encontros nacionais em Brasília e que contribuíram significativamente para trazer a questão da política para a infância como debate nacional. As crianças e adolescentes apareceram como sujeitos de direitos como cidadãos.

A partir das lutas e pressões sociais, e dentro das correlações de forças possíveis, em 1986, o Congresso Nacional funciona como Assembléia Constituinte. Surgia então uma nova ordem jurídica política e social para a sociedade, com a Constituição Federal de 1988.

Com a nova ordem jurídica advinda da Constituição de 1988 os direitos da criança e do adolescente perpassam as diferentes áreas, mas ficam bem estabelecidos nos artigos 227, 228, e

\footnotetext{
${ }^{27}$ FALEIROS. Vicente de Paulo. Uma Década de Direitos: Avaliação dos dez anos de Estatuto da Criança e do Adolescente. Série Escola de Conselhos. Cadernos para a Cidadania. Brasília: CECRIA, 2000.
} 
229 da referida Constituição. Garante-se à criança e ao adolescente, como dever do Estado e da sociedade os direitos à vida, saúde, educação, ao lazer, à profissionalização, cultura, dignidade, ao respeito, liberdade, e à convivência familiar e comunitária, além de colocá-los a salvo de toda a forma de negligência, discriminação, exploração, violência, crueldade e opressão.

O processo de ruptura não se realizou de forma abrupta, mas num constante conflito que, reflete a correlação de forças sociais entre os que defendem posições de repressão, assistencialismo, cidadania e outros que defendem o mercado em primeiro lugar.

Ainda como forma de regular as disposições da Constituição Federal de 1988 surge a Lei ${ }^{\circ}$ 8.069, de 13 de julho de 1990, denominada Estatuto da Criança e do Adolescente - ECA regulamentou o art. 227 da Constituição de 1988, que estabelece os direitos fundamentais da criança e do adolescente. Além disso, o Estatuto hamoniza-se com a Convenção sobre os Direitos da Criança e do Adolescente, aprovada pela Assembléia Geral das Nações Unidas, em 20 de novembro de 1989.

Ao contrário das leis que nasceram em gabinetes o Estatuto da Criança e do Adolescente é fruto de uma intensa mobilização da sociedade civil. A partir de 1986, quando o país se preparava para redigir uma nova Constituição, teve início um movimento de entidades da sociedade civil para influenciar a Assembléia Nacional Constituinte a favor da infância e da adolescência.

Com o Estatuto da Criança e do Adolescente - ECA a criança e o adolescente são considerados cidadãos protagonistas de sua trajetória de acordo com o seu desenvolvimento, as crianças e adolescentes passam a gozar de todos os direitos fundamentais inerentes à pessoa humana e devem ter prioridade absoluta da família da sociedade e do Estado; é estabelecido o fim da política de abrigamento, a não ser em casos excepcionais; é instituída a prioridade das medidas de proteção sobre as medidas sócio educativas, deixando-se de focalizar a política da infância nos abandonados e delinqüentes. $^{28}$

\footnotetext{
${ }^{28}$ FALEIROS. Vicente de Paulo. Uma Década de Direitos: Avaliação dos dez anos de Estatuto da Criança e do Adolescente. Série Escola de Conselhos. Cadernos para a Cidadania. Brasília: CECRIA, 2000.
} 
Quando aos infratores é garantido o devido processo penal para o adolescente a quem se atribua prática de ato infracional; são estabelecidas as limitações dos poderes da autoridade judiciária e a implementação dos Conselhos Tutelares como instância socioeducacional colegiada escolhida pela comunidade; e ainda definiu a implementação de mecanismos de proteção dos interesses difusos e coletivos. ${ }^{29}$

A participação e o controle social são garantidos na deliberação sobre as políticas de infância e do adolescente por meio dos Conselhos de Direitos, em todos os níveis de governo como órgãos paritários; e é estabelecida a integração e articulação de ações governamentais e nãogovernamentais na política de atendimento. ${ }^{30}$

Deste modo o ECA significa um grande avanço para a Política de Proteção aos Direitos da Criança e do Adolescente que em síntese se dividiu, historicamente, em três momentos: o primeiro é o predomínio da caridade e da filantropia, o segundo a consolidação do sistema jurídicoadministrativo e o terceiro a criança e o adolescente como sujeito de direitos.

\subsection{O Estado Democrático de Direito e a Proteção aos Direitos da Criança e do Adolescente}

Os princípios e concepções trazidas pelo ECA consideram a doutrina de proteção integral como base e sistema de garantia dos direitos da criança e do adolescente. As crianças e os adolescentes não são mais considerados menores ou incapazes, mas pessoas em desenvolvimento para se tornarem protagonistas e sujeitos de direitos e passarem a assumir plenamente suas responsabilidades dentro da comunidade, em função do pleno desenvolvimento de sua personalidade.

A doutrina da proteção integral está contextualizada num processo histórico de construção de uma nova institucionalidade emergente na sociedade brasileira, em ruptura com as

\footnotetext{
${ }^{29}$ FALEIROS. Vicente de Paulo. Uma Década de Direitos: Avaliação dos dez anos de Estatuto da Criança e do Adolescente. Série Escola de Conselhos. Cadernos para a Cidadania. Brasília: CECRIA, 2000.

${ }^{30}$ Ibidem.
} 
dimensões inerentes a um padrão de relações autoritários, centralizado, repressivo, clientelista e de políticas fragmentadas.

O Estatuto da Criança e do Adolescente prevê em seu texto a criação do Sistema de Garantia de Direitos proposto para uma gestão articulada dos direitos da infância e adolescência. ${ }^{31}$ O Artigo 86 do Estatuto da Criança e do Adolescente, por exemplo, determina que "a política de atendimento de criança e do adolescente far-se-á por meio de um conjunto articulado de ações governamentais e não-governamentais da União, dos estados, do Distrito Federal e dos municípios".

De acordo com a socióloga, Marlene Vaz, o sistema surgiu da necessidade de se interpretar essa determinação do ECA. O Sistema de Garantia de Direitos da Criança e do Adolescente compreende três eixos de atuação: promoção, controle social e defesa dos direitos. ${ }^{32}$

A promoção tem por objetivo específico o atendimento direto, que pretende garantir o acesso universal e prioritário de crianças e adolescentes aos serviços públicos básicos, como assistência, educação e saúde. Nesse espaço também se encontram políticas e órgãos de proteção e atendimento de direitos de crianças e adolescentes. O instrumento para concretizar estes objetivos é a elaboração das próprias políticas sociais e, na sua falta, os programas especiais de atenção.

O controle tem objetivo de exercer vigilância sobre a política e o uso de recursos públicos para a área da infância e da adolescência, bem como o monitoramento e controle tanto de ações de organizações não-governamentais quanto de órgãos governamentais. É um espaço de sociedade civil organizada, representada nos fóruns, frentes, pactos, e dos Conselhos de Direitos.

A defesa tem por objetivo específico verificar o não atendimento, o atendimento irregular ou a violação dos direitos da criança e do adolescente. É o espaço de Conselhos Tutelares, Poder Judiciário (especialmente Juizado da Infância e da Juventude), Ministério Público, Secretarias da Justiça (órgãos de defesa da cidadania), Secretaria de Segurança Pública (Polícias), Defensoria

\footnotetext{
${ }^{31}$ Embora não exista na legislação brasileira nenhuma menção específica a essa rede, a idéia de articulação está presente nas leis.

${ }^{32}$ Apud. VIVARTA, Veet (coord). Ouvindo Conselhos: democracia participativa e direitos da infância na pauta das redações brasileiras. São Paulo: Cortez, 2005.
} 
Publica, Ordem dos Advogados do Brasil, Centros de Defesa da Criança e do Adolescente e outras associações legalmente constituídas.

O Estado Democrático de Direito é instituído no art. $1^{\circ}$ da Constituição Federal de 1988. isto quer dizer que os valores da democracia devem irradiar todos os elementos constitutivos do estado. Neste sentido o direito imantado por estes valores deve seguir o interesse coletivo.

Neste Estado a democracia, então, será realizada por meio de um processo de convivência social, levando em conta que o poder emana do povo e em nome dele deve ser exercido, propiciando a participação do povo no processo decisório, respeitando a pluralidade de idéias e de opiniões. Logo, o Estado Democrático de Direito tem um papel fundamental de realizar a síntese do processo contraditório do mundo contemporâneo, "superando" o Estado capitalista para configurar um Estado promotor de justiça social. Reforçando tal entendimento vale citar José Afonso da Silva, verbis:

“A democracia que o Estado Democrático de Direito realiza há de ser um processo de convivência social livre, justa e solidária (art.3 $3^{\circ}, \mathrm{I}$ ), que o poder emana do povo, e deve ser exercido em proveito do povo, diretamente ou por representantes eleitos (art. $1^{\circ}$, parágrafo único); participativa, porque envolve a participação crescente do povo no processo decisório e na formação dos atos de governo; pluralista, porque respeita a pluralidade de idéias, culturais e etnias e pressupõem assim o diálogo entre opiniões e pensamentos divergentes e a possibilidade de convivência de formas de organização de interesses diferentes da sociedade; há de ser um processo de libertação da pessoa humana das formas de opressão que não depende apenas do reconhecimento formal de certos direitos individuais, políticos e sociais, mas especificamente da vigência de condições econômicas suscetíveis de favorecer o seu pleno exercício". 33

Portanto, está presente nos valores da Constituição de 1988 a possibilidade de participação social no processo decisório, o que legitima a criação dos Conselhos de Direitos como órgãos pertencentes ao sistema descentralizado de gestão das políticas públicas, para entender melhor como este processo irá ocorrer se faz necessário compreender o sistema federativo.

Quanto à forma de Estado o Brasil optou pelo federalismo que consiste na reunião de vários Estados num só, cada qual com certa independência, autonomia interna, mas obedecendo

${ }^{33}$ SILVA, José Afonso. Curso de Direito Constitucional Positivo. São Paulo: Malheiros, 2005. 
todos a uma Constituição única. Com esta forma de estado o país pretendeu descentralizar o poder, cabendo a todos os Estados, Município e Distrito Federal uma parcela de responsabilidade nas decisões do país. ${ }^{34}$

Deste modo podemos concluir que o sistema federativo permite a descentralização da decisão e a repartição de poderes e responsabilidades. Neste sentido não é apenas ao Governo Federal que cabe à execução e fiscalização da Política de Proteção aos Direitos da Criança e do Adolescente, os Estados e Municípios também são responsáveis neste processo de descentralização de poder.

A nova institucionalização implica não só uma democratização do Estado, mas um processo de participação da sociedade na gestão pública, principalmente, por meio da implementação de conselhos paritários, com o poder de decisão sobre determinados temas. Há, portanto, uma nova, relação de poder, que traduz, evidentemente, na arena política, conflitos vigentes não só entre instituinte e o instituído, mas a emergência de tensões entre atores que entram em cena e aqueles que vinham detendo o poder hegemônico.

A concepção de controle social advém da Constituição Federal de 1988, momento político-ideológico em que a participação popular e os mecanismos de efetivação da democracia são garantidos na lei maior. O controle social é um mecanismo democrático no processo de gestão político-administrativa-financeira e técnico-operativa e uma possibilidade de participação da sociedade na gestão de políticas públicas.

Segundo Raichelis controle social ou democracia direta consiste na participação da sociedade civil, na gestão e organização das entidades públicas e privadas. ${ }^{35}$ Esta participação se dá por meio dos Fóruns, Conferências, e especialmente por meio dos Conselhos de Direitos, que são órgãos normativo, deliberativo e fiscalizador da Política Social, sendo este órgão integrante do sistema descentralizado.

\footnotetext{
${ }^{34}$ SILVA, José Afonso. Curso de Direito Constitucional Positivo. São Paulo: Malheiros, 2005.

${ }^{35}$ RAICHELIS, Raquel. Esfera Pública e Conselhos de Assistência Social: caminhos da construção democrática. São Paulo: Cortez, 1998.
} 


\subsubsection{Os Conselhos de Direitos e o Controle Social}

No dicionário Aurélio o termo "conselho" é definido como: 1) parecer, juízo, definição, opinião; 2) advertência, aviso; 3) prudência; 4) corpo coletivo superior; 5) tribunal; 6) reunião ou assembléia de ministros; 7) corporação à qual incumbe opinar aconselhar sobre certos negócios públicos; 8) reunião de pessoas para tratarem de assunto particular; e 9) reunião de professores para tratarem de assuntos de ensino ou de ordem. Apesar de algumas definições se aproximarem do significado de Conselho de Direitos a concepção posta na legislação é mais específica.

No caso da assistência social a Lei Orgânica da Assistência Social - LOAS em seu art. $5^{\circ}$ prevê a participação popular, com base na descentralização político-administrativa para os Estados, Distrito Federal e Municípios, o comando único em cada esfera de governo, e a primazia da responsabilidade do Estado na condução da política de assistência social em cada esfera de governo. E no art. 16. prevê a criação dos Conselhos de Assistência Social como instâncias deliberativas do sistema descentralizado e participativo de assistência social, de caráter permanente e composição paritária entre governo e sociedade civil

Para o Estatuto da Criança e do Adolescente - ECA, especialmente nos arts. 88 a 91, os Conselhos de Direitos e os Conselhos Tutelares são entendidos como mecanismos democráticos de participação e representação política da sociedade civil na gestão políticoadministrativa do Estado.

Neste sentido segundo Orlando Alves dos Santos Junior "os conselhos estão se consolidando como uma arena de interação entre o governo e a sociedade" ${ }^{36}$, sendo estes de acordo com Rubem Sião Praestes, sem dúvida, a "maior alteração produzida na administração pública brasileira nos últimos tempos". 37

\footnotetext{
${ }^{36}$ Apud. VIVARTA, Veet (coord). Ouvindo Conselhos: democracia participativa e direitos da infância na pauta das redações brasileiras. São Paulo: Cortez, 2005.

${ }^{37}$ Ibidem.
} 
Atuando na defesa e na proteção dos direitos das crianças e adolescentes do Distrito Federal destaca-se, dentre outros ${ }^{38}$, o Conselho da Assistência Social - CAS/DF, o Conselho de Direitos da Criança e do Adolescente - CDCA/DF.

No âmbito da proteção dos direitos da criança e do adolescente no Distrito Federal a política de controle social é realizada pelo Conselho de Assistência Social do Distrito Social CAS/DF e pelo Conselho dos Direitos da Criança e do Adolescente - CDCA/DF, conforme o quadro abaixo:

Tabela 1. Como se dá a execução e o controle social da Política de Proteção aos Direitos da Criança e do Adolescente

\begin{tabular}{|c|c|c|}
\hline Programas & $\begin{array}{l}\text { Órgão responsável pela } \\
\text { execução da Política }\end{array}$ & $\begin{array}{l}\text { Órgão responsável pelo } \\
\text { Controle Social }\end{array}$ \\
\hline \multirow{2}{*}{$\begin{array}{l}\text { Programa e Defesa dos } \\
\text { Direitos da Criança e do } \\
\text { Adolescente }\end{array}$} & $\begin{array}{l}\text { No âmbito Federal é a Secretaria } \\
\text { Especial dos Direitos Humanos. }\end{array}$ & $\begin{array}{llll}\text { No âmbito } & \text { Federal é } & \text { o } \\
\text { CONANDA. } & & & \\
\end{array}$ \\
\hline & $\begin{array}{l}\text { No âmbito do Distrito Federal é } \\
\text { a Secretaria de Justiça e de } \\
\text { Direitos Humanos. }\end{array}$ & $\begin{array}{l}\text { No âmbito do Distrito Federal é } \\
\text { o CDCA/DF. }\end{array}$ \\
\hline \multirow{2}{*}{$\begin{array}{l}\text { Programa de Atendimento } \\
\text { Sócio Educativo ao } \\
\text { Adolescente em conflito } \\
\text { com a Lei }\end{array}$} & $\begin{array}{l}\text { No âmbito Federal é a Secretaria } \\
\text { Especial dos Direitos Humanos }\end{array}$ & $\begin{array}{llll}\text { No âmbito } & \text { Federal é } & \text { o } \\
\text { CONANDA } & & & \end{array}$ \\
\hline & $\begin{array}{l}\text { No âmbito do Distrito Federal é } \\
\text { a Secretaria de Justiça e de } \\
\text { Direitos Humanos. }\end{array}$ & $\begin{array}{l}\text { No âmbito do Distrito Federal é } \\
\text { o CDCA/DF. }\end{array}$ \\
\hline \multirow[b]{2}{*}{$\begin{array}{l}\text { Combate ao Abuso e à } \\
\text { Exploração Sexual de } \\
\text { Crianças e Adolescentes }\end{array}$} & $\begin{array}{l}\text { No âmbito Federal é a Secretaria } \\
\text { Especial dos Direitos Humanos. }\end{array}$ & $\begin{array}{l}\text { No âmbito Federal é } \\
\text { CONANDA. }\end{array}$ \\
\hline & $\begin{array}{l}\text { No âmbito do Distrito Federal é } \\
\text { a Secretaria de Justiça e de } \\
\text { Direitos Humanos. }\end{array}$ & $\begin{array}{l}\text { No âmbito do Distrito Federal é } \\
\text { o CDCA/DF. }\end{array}$ \\
\hline \multirow{2}{*}{$\begin{array}{l}\text { Projeto Agente Jovem de } \\
\text { Desenvolvimento Humano }\end{array}$} & $\begin{array}{l}\text { No âmbito Federal é o } \\
\text { Ministério do Desenvolvimento } \\
\text { Social. }\end{array}$ & No âmbito Federal é o CNAS. \\
\hline & $\begin{array}{l}\text { No âmbito Distrito Federal é a } \\
\text { Secretaria de Ação Social - } \\
\text { SEAS. }\end{array}$ & $\begin{array}{l}\text { No âmbito do Distrito Federal é } \\
\text { o CAS/DF. }\end{array}$ \\
\hline
\end{tabular}

${ }^{38}$ Com o exemplo de Conselhos que atuam na defesa dos direitos da criança e do adolescente pode-se citar o Conselho da Saúde, da Educação, da Assistência Social, dos Direitos da Criança e do Adolescente, etc. 


\begin{tabular}{|c|c|c|}
\hline \multirow[t]{2}{*}{ Ações Sócio Educativas } & $\begin{array}{l}\text { No âmbito } \quad \text { Federal é ó } \\
\text { Ministério do Desenvolvimento } \\
\text { Social. }\end{array}$ & No âmbito Federal é o CNAS. \\
\hline & $\begin{array}{l}\text { No âmbito Distrito Federal é a } \\
\text { Secretaria de Ação Social - } \\
\text { SEAS. }\end{array}$ & $\begin{array}{l}\text { No âmbito do Distrito Federal é } \\
\text { o CAS/DF. }\end{array}$ \\
\hline \multirow{2}{*}{$\begin{array}{l}\text { Serviços Continuados para } \\
\text { Atendimento à Criança } \\
\text { (BPC) }\end{array}$} & $\begin{array}{l}\text { No âmbito } \text { Federal é ó } \\
\text { Ministério do Desenvolvimento } \\
\text { Social. }\end{array}$ & No âmbito Federal é o CNAS. \\
\hline & $\begin{array}{l}\text { No âmbito Distrito Federal é a } \\
\text { Secretaria de Ação Social - } \\
\text { SEAS. }\end{array}$ & $\begin{array}{l}\text { No âmbito do Distrito Federal é } \\
\text { o CAS/DF. }\end{array}$ \\
\hline \multirow{2}{*}{$\begin{array}{c}\text { Proteção Especial de } \\
\text { Média Complexidade } \\
\text { (Centros de Referência } \\
\text { Especializados de } \\
\text { Assistência Social - } \\
\text { CREAS*) }\end{array}$} & $\begin{array}{l}\text { No âmbito Distrito Federal é a } \\
\text { Secretaria de Ação Social - } \\
\text { SEAS. }\end{array}$ & No âmbito Federal é o CNAS. \\
\hline & $\begin{array}{l}\text { No âmbito Distrito Federal é a } \\
\text { Secretaria de Ação Social - } \\
\text { SEAS. }\end{array}$ & $\begin{array}{l}\text { No âmbito do Distrito Federal é } \\
\text { o CAS/DF. }\end{array}$ \\
\hline \multirow{2}{*}{$\begin{array}{l}\text { Proteção Especial de Alta } \\
\text { Complexidade } \\
\text { (Programa de erradicação } \\
\text { do trabalho infantil - } \\
\text { PETI**, Sistema Único da } \\
\text { Assistência Social - } \\
\text { SUAS*** e Serviços de } \\
\text { proteção à criança e } \\
\text { adolescente vítima de } \\
\text { violência, abuso e } \\
\text { exploração sexual****) }\end{array}$} & $\begin{array}{l}\text { No âmbito Federal é o o } \\
\text { Ministério do Desenvolvimento } \\
\text { Social. }\end{array}$ & No âmbito Federal é o CNAS. \\
\hline & $\begin{array}{l}\text { No âmbito Distrito Federal é a } \\
\text { Secretaria de Ação Social - } \\
\text { SEAS. }\end{array}$ & $\begin{array}{l}\text { No âmbito do Distrito Federal é } \\
\text { o CAS/DF. }\end{array}$ \\
\hline
\end{tabular}

*Serviços de media complexidade são aqueles que oferecem atendimentos às famílias e indivíduos com seus direitos violados, mas cujos vínculos familiares e comunitários não foram rompidos. Neste sentido, requerem maior estruturação técnicooperacional e atenção especializada e mais individualizada, e, ou, de acompanhamento sistemático e monitorado. Estas atividades são desenvolvidas pelos Centros de Referência Especializados de Assistência Social.

** O PETI é um programa de transferência direta de renda para famílias de crianças e adolescentes em situação de trabalho, adicionado à oferta de Ações Socioeducativas e de Convivência, manutenção da criança/adolescente na escola e articulação dos demais serviços da rede de proteção básica e especial.

*** O SUAS hoje é o objetivo da Política de Assistência Social, inspirado no SUS, pretende facilitar o acesso à assistência social.

**** Serviço que oferece um conjunto de procedimentos técnicos especializados para atendimento e proteção imediata às crianças e aos adolescentes vítimas de abuso ou exploração sexual, bem como seus familiares, proporcionando-lhes condições para o fortalecimento da auto-estima, superação da situação de violação de direitos e reparação da violência vivida.

\subsubsection{O Conselho de Assistência Social do Distrito Federal - CAS/DF}

O Conselho de Assistência Social do Distrito Federal - CAS/DF foi criado pela Lei n 997, de 29 de dezembro de 1995, como órgão público de caráter permanente e competência 
normativa e deliberativa na formulação da Política de Assistência Social, integrante do sistema descentralizado de Assistência Social, vinculado administrativamente à Secretaria de Desenvolvimento Social e Ação Comunitária do Distrito Federal ${ }^{39}$, responsável pela coordenação e execução da Política de Assistência Social do Distrito Federal.

Sua criação está fundamentada na Lei Orgânica de Assistência Social - LOAS, Lei $\mathrm{n}^{\mathrm{o}} 8.742$, de 7 de dezembro de 1993, que em seu artigo $9^{\text {a }}$, prevê que o funcionamento das entidades e organizações de assistência social depende de prévia inscrição no respectivo Conselho Municipal de Assistência Social, ou no Conselho de Assistência Social do Distrito Federal, conforme o caso.

Ainda de acordo com o artigo 16 da LOAS, o Conselho de Assistência Social do Distrito Federal serão instâncias deliberativas do sistema descentralizado e participativo de assistência social, de caráter permanente e composição paritária entre governo e sociedade civil.

O CAS/DF é composto, de forma colegiada e paritária, por representantes de órgãos públicos e por representantes de usuários da Assistência Social, trabalhadores da área de Assistência Social e entidades não-governamentais prestadoras de serviços, benefícios, assessoramento e defesa de direitos, devidamente inscrita no CAS/DF.

O CAS/DF é composto de 20 Conselheiros titulares e os respectivos suplentes, nomeados pelo Governador do Distrito Federal.

Os 10 representantes do Governo serão indicados pelos seguintes órgãos: Secretaria de Ação Social; Secretaria de Trabalho e Direitos Humanos; Secretaria de Saúde; Secretaria de Desenvolvimento Social; Secretaria de Infra-Estrutura e Obras; Secretaria de Governo; Secretaria de Educação; Secretaria de Cultura; Secretaria da Fazenda e Planejamento; e Universidade de Brasília - UnB.

${ }^{39}$ Apesar da Lei acima mencionar a Secretaria de Desenvolvimento Social e Ação Comunitária do Distrito Federal, hoje (2007) ela é denominada de Secretaria de Ação Social - SEAS, e o CAS/DF é órgão vinculado à esta Secretaria, mesmo a Lei não deixando claro, vale salientar que a instituição, mesmo estando vinculada à SEAS, é um órgão autônomo na normatização e deliberação sobre a política de assistência social, tendo inclusive recursos próprios. 
Os 10 membros da sociedade civil devem representar entidades não governamentais de prestação de serviços, assessoramento e defesa, organizações dos destinatários da Assistência Social e trabalhadores da área, escolhidos em Assembléia especialmente reunida para este fim pelo voto da maioria dos presentes, sob a fiscalização do Ministério Público do Distrito Federal e Territórios. Ficando assegurados a representação do Governo e da Sociedade Civil na Presidência e Vice-Presidência do CAS/DF, e a alternância dessas representações em cada mandato, e assim sucessivamente, com exceção dos casos de recondução por igual período.

Diante desta exigência da Lei Federal os Municípios e o Distrito Federal tiveram que reorganizar a Assistência Social, criando os Conselhos de Assistência Social que tem por finalidade fiscalizar e normatizar a Política de Assistência Social dos Municípios e do Distrito Federal.

O CAS/DF definiu em seu Regimento Interno ${ }^{40}$, como objetivos de atuação institucional efetivar, no âmbito do Distrito Federal, o processo descentralizado e participativo da Assistência Social, previsto na Constituição Federal, na LOAS e na Lei Orgânica do Distrito Federal; aprovar, com base nas prioridades e diretrizes estabelecidas pela Conferência de Assistência Social do Distrito Federal, proposta de Política de Assistência Social a ser encaminhada pela Secretaria de Ação Social do Distrito Federal; funcionar em articulação com o Conselho Nacional de Assistência Social - CNAS, Conselhos Distritais congêneres e órgãos formuladores e executivos de políticas setoriais de desenvolvimento sócio-econômico, mantendo interfaces com estes diferentes organismos; atuar em consonância com as normas, critérios, políticas e orientações emanadas do CNAS; zelar pela transparência da Política de Assistência Social no Distrito Federal; e respaldar a Política de Assistência Social em atividades permanentes de estudos, pesquisas e capacitação de recursos humanos, preservando a sua qualidade e adequação à realidade do Distrito Federal.

O CAS/DF contribui para a Política de Assistência Social na realização da Conferência de Assistência Social, que é um espaço amplo e aberto para a deliberação e apontamentos dos rumos da Assistência Social do Distrito Federal. As informações e deliberações desta Conferência serão apresentadas na Conferência Nacional de Assistência Social, junto com as

\footnotetext{
${ }^{40}$ DISTRITO FEDERAL. Resolução no 12, de 6 de agosto de 2002, Dispõe sobre o Regimento Interno do Conselho de Assistência Social do Distrito Federal - CAS/DF.
} 
demais deliberações dos Estados e Municípios. A Conferência Nacional é organizada pelo Conselho Nacional de Assistência Social - CNAS, órgão vinculado à esfera federal e responsável pela elaboração do Plano Nacional de Assistência Social.

As decisões aprovadas no Plano Nacional de Assistência Social devem ser implementadas nos Estados, Distrito Federal e Municípios, cabendo aos Conselhos de Assistência Social, integrante do sistema descentralizado, o acompanhamento, a fiscalização e o controle desta política.

O atual Plano Nacional de Assistência Social ${ }^{41}$ prevê que para a consolidação da assistência como uma política social seria necessária a implementação do Sistema Único de Assistência Social - SUAS, cujo fundamento é o pacto federativo. Mas a centralização ainda é uma marca a ser superada.

Ainda para dar maior eficiência e eficácia a esta política são necessários a construção de redes sociais e o fortalecimento dos órgãos de controle social. Neste sentido reafirmase a importância do Conselho de Assistência Social do Distrito Federal - CAS/DF como órgão normativo e fiscalizador da Política de Assistência Social.

Contudo, verifica-se que as atividades do Conselho, ainda estão relacionadas com a burocracia de procedimentos o que impede muitas vezes a efetivação de todas suas competências, ainda há que se destacar a falta de capacitação constante para os conselheiros que muitas vezes não conseguem interferir de forma adequada na questão orçamentária, e da própria política.

Os próprios mecanismos de controle e fiscalização efetiva das entidades ainda são deficientes uma vez que a visita institucional para realizar a fiscalização da entidade, só é realizada no momento do pedido de inscrição ou de revalidação da inscrição do CAS/DF, que se dá a cada 5 anos. Durante este intervalo as entidades devem enviar anualmente a prestação de contas, entretanto o CAS/DF não tem como acompanhar esta prestação de contas, por falta de pessoal especializado, o que gera uma fiscalização ineficaz, não sistemática e descontinuada das entidades.

\footnotetext{
${ }^{41} \mathrm{O}$ atual Plano Nacional de Assistência Social foi publicado no dia 28 de outubro de 2004, e tem validade por até 2008, ano em que será elaborado novo Plano Nacional de Assistência Social. A próxima Conferência de Assistência do Distrito Federal ocorrerá em meados de outubro de 2007.
} 
Percebe-se também que o CAS/DF não efetiva sua competência de ser o divulgador das políticas de assistência social, sendo um dever também deste conselho divulgar a política de assistência social, visando seu aperfeiçoamento e valorização.

Portanto, quanto à competência do CAS/DF percebe-se que ainda faltam aspectos a serem organizados para que a Instituição possa exercer suas atribuições de forma plena.

\subsubsection{O Conselho dos Direitos da Criança e do Adolescente do Distrito Federal - CDCA/DF}

O Conselho dos Direitos da Criança e do Adolescente do Distrito Federal CDCA/DF é regulamentado pela Lei $\mathrm{n}^{\mathbf{0}}$ 3033, de 18 de julho de 2002, como órgão deliberativo e controlador das ações da política de atendimento aos direitos da criança e do adolescente, fica vinculado administrativamente à Secretaria de Estado de Ação Social do Distrito Federal ${ }^{42}$, que proporcionará os meios necessários ao seu funcionamento.

A criação do CDCA/DF advém da própria previsão da Constituição Federal de 1988 e do Estatuto de Criança e do Adolescente que cria um Sistema de Garantias, onde os Conselhos de Direitos e os Conselhos Tutelares têm papel fundamental.

De acordo com a Lei 3.033, de 18 de julho de 2002, o CDCA/DF tem como atribuições formular a política de proteção dos direitos da criança e do adolescente e definir suas prioridades; controlar e acompanhar as ações governamentais e não-governamentais na execução da política de atendimento dos direitos da criança e do adolescente; gerir o Fundo dos Direitos da Criança e do Adolescente do Distrito Federal, de que trata o art. $9^{\circ}$ da Lei $\mathrm{n}^{\circ} 234$, de 15 de janeiro de 1992, modificada pela Lei n ${ }^{o}$ 518, de 30 de julho de 1993, definindo a política de captação, administração e aplicação dos seus recursos financeiros; assessorar o Poder Executivo na elaboração da proposta orçamentária, no que se refere à destinação de recursos públicos para as áreas relacionadas com a política de atendimento aos direitos da criança e do adolescente; inscrever, na forma das normas a serem fixadas, os programas governamentais e não-governamentais, observado o disposto no art. 90 do Estatuto da Criança e do Adolescente; registrar, na forma das normas a serem

\footnotetext{
${ }^{42}$ Em 2007 após a posse do novo Governador de Estado, José Roberto Arruda, o CDCA/DF é vinculado ao PróConselhos órgão da Secretaria de Justiça e de Direitos Humanos.
} 
fixadas, as organizações não-governamentais com atuação na área da infância e da adolescência no Distrito Federal, observado o disposto no art. 91 do Estatuto da Criança e do Adolescente; propor e acompanhar, sempre que necessário, o reordenamento institucional, indicando modificações nas estruturas públicas e privadas destinadas ao atendimento da criança e do adolescente; promover, apoiar e incentivar a realização de estudos, pesquisas e eventos sobre a política e as ações de atendimento dos direitos da criança e do adolescente; avaliar a política e as ações de atendimento dos direitos da criança e do adolescente no âmbito do Distrito Federal; regulamentar, organizar e coordenar o processo de escolha dos membros dos Conselhos Tutelares; apoiar os Conselhos Tutelares e os órgãos governamentais e não-governamentais para tornar efetivos os direitos da criança e do adolescente estabelecidos na Lei Federal nº 8.069, de 1990; convocar, ordinariamente, a cada dois anos, a Conferência Distrital dos Direitos da Criança e do Adolescente, para avaliar a política e as ações de atendimento dos direitos da criança e do adolescente no Distrito Federal e propor diretrizes para o seu aperfeiçoamento; realizar e incentivar a realização de campanhas promocionais e de conscientização dos direitos da criança e do adolescente; e cumprir o seu regimento interno.

Quanto à política de proteção ao direito da criança e do adolescente o CDCA/DF segue as orientações do CONANDA, quanto às prioridades de intervenção da política, que em 1996 definiu como eixos prioritários de intervenção o trabalho infantil, a violência e a exploração sexual e o ato infracional (medida sócio-educativa), o que representou um significativo avanço para a Política de Proteção aos direitos da criança e do adolescente. Neste sentido vale citar a seguinte passagem:

"A iniciativa do Conselho Nacional em debater esses eixos em assembléias ampliadas obteve boa repercussão junto aos Estados, sobretudo, quanto ao incentivo para que a discussão acontecesse de forma ampla, resultado em intensa mobilização, não apenas entre os Conselhos como também entre as diversas entidades e organizações da área. Os três eixos contribuíram para o trabalho dos Conselhos Estaduais que fazem seu acompanhamento e implementação, mediante comissões, parcerias com ONGs, diagnóstico e elaboração de subsídios. (...) As diretrizes do CONANDA também contribuíram para a formulação do Plano de Ação do Departamento da Criança e do Adolescente do Ministério da Justiça, voltado especialmente para o atendimento ao adolescente em conflito com a lei." ${ }^{3}$

\footnotetext{
${ }^{43}$ Apud. FALEIROS. Vicente de Paulo. Uma Década de Direitos: Avaliação dos dez anos de Estatuto da Criança e do Adolescente. Série Escola de Conselhos. Cadernos para a Cidadania. Brasília: CECRIA, 2000.
} 
O CDCA/DF é integrado por representantes do Poder Executivo e por organizações representativas da sociedade com atuação na área da infância e da adolescência no Distrito Federal, sendo paritária a participação do Governo e da Sociedade Civil. É composto por vinte membros titulares e seus respectivos suplentes.

Serão 10 (dez) dos membros do Governo (Poder Executivo), indicados pelos titulares da Secretaria de Estado de Ação Social; Secretaria de Estado de Cultura; Secretaria de Estado de Educação; Secretaria de Estado de Esporte e Lazer; Secretaria de Estado de Fazenda e Planejamento; Secretaria de Estado de Governo; Secretaria de Estado de Saúde; Secretaria de Estado de Segurança Pública; Secretaria de Estado de Trabalho e Direitos Humanos; Centro de Assistência Judiciária do Distrito Federal.

Os membros da Sociedade Civil também serão 10 (dez) representantes de organizações representativas da sociedade civil, legalmente constituídas, distribuídas da seguinte forma: a) 06 (seis) representantes com atuação na área de atendimento direto à infância e adolescência no Distrito Federal há mais de um ano e com registro no CDCA-DF; b) 02 (dois) representantes de entidades de classe que atuem na área da criança e do adolescente no Distrito Federal; c) 02 (dois) representantes de entidades de estudo, pesquisa e defesa de direitos que atuem no Distrito Federal há mais de um ano.

A escolha das organizações representativas da sociedade que farão parte do CDCA/DF será feita mediante eleição, realizada em assembléia especialmente convocada para este fim, pelo voto da maioria simples dos delegados presentes e sob fiscalização do Ministério Público do Distrito Federal.

O exercício da função de conselheiro é considerado de interesse público relevante e não será remunerado. Requer ainda o compromisso com a missão institucional do CDCA - DF e em relação a seu órgão ou sua organização, devendo atender aos requisitos como: o efetivo exercício de suas funções no seu órgão ou sua organização; formação acadêmica ou comprovada atuação na área da criança e do adolescente; pertencer, preferencialmente, à diretoria ou ocupar cargos diretivos na organização representativa. 
Vale ainda fazer uma diferenciação entre o perfil dos Conselhos de Direitos com relação aos Conselhos Tutelares, apesar deste não ser o tema principal deste Trabalho.

Quanto à função principal os Conselhos de Direitos são órgãos criados por lei para formular e deliberar sobre as políticas públicas relativas à criança e adolescente, em suas interfaces com as áreas de saúde, meio ambiente, assistência social e educação, por exemplo. Também devem organizar redes de atenção à população infanto-juvenil, promovendo a articulação das ações, das entidades e dos programas da sociedade civil e dos governos. Devem existir nos âmbitos municipal estadual e nacional. Já os Conselhos Tutelares também devem ser criados por lei (municipal) e cada cidade deve ter, no mínimo, um Conselho Tutelar. São encarregados de zelar pelo cumprimento dos direitos da criança e do adolescente, estando vinculados aos anseios e às demandas da sociedade em relação a esses segmentos etários. Têm função privilegiada na assessoria as poderes Executivo e Legislativo na elaboração do orçamento para planos e programas de atendimento dos direitos da criança e do adolescente. ${ }^{44}$

Quanto aos conselheiros percebe-se que os Conselhos de Direitos são formados paritariamente por integrantes do poder público e da sociedade civil, escolhidos em fórum próprio. A função dos conselheiros é considerada de interesse público relevante e não é remunerada. Já os Conselhos tutelares são formados por cinco membros escolhidos pela própria comunidade para mandato de três anos, por meio de eleição. Hoje, em boa parte dos municípios remunera-se a atividade de conselheiro tutelar, inclusive no Distrito Federal. ${ }^{45}$

Quanto à atuação de cada Conselho vale ressaltar que o Conselho Nacional dos Direitos da Criança e do Adolescente - CONANDA delibera sobre as questões de âmbito nacional, enquanto os Conselheiros Estaduais e Municipais têm como política de atendimento no âmbito dos estados e em nível local, respectivamente. Costumam ter Assembléias mensais e contar Comissões de Trabalho (Políticas Públicas, Orçamento, e Fundos, entre outros) formadas pelos conselheiros. Quando dispõem de uma secretaria executiva e grupo de apoio técnico, tem maior eficiência e agilidade nos encaminhamentos. Os Conselhos Tutelares atuam diretamente para a garantia da oferta

\footnotetext{
${ }^{44}$ Apud. VIVARTA, Veet (coord). Ouvindo Conselhos: democracia participativa e direitos da infância na pauta das redações brasileiras. São Paulo: Cortez, 2005.

${ }^{45}$ Ibidem.
} 
dos direitos. Para tanto, podem requisitar serviços públicos nas áreas de saúde e educação. Aqui acontece a relação é mais direta com a população que pode recorrer aos Conselhos Tutelares sempre que tiver um direito violado ou negado. Devem contar com sede, equipamentos e dispor de apoio técnico as diferentes áreas, fornecidos pelo Poder Executivo Municipal. ${ }^{46}$

Verifica-se que os Conselhos de Direitos são compostos de forma paritária e mantém certo grau de identidade entre si, contudo percebe-se que na prática estes Conselhos ainda não conseguiram desenvolver mecanismos que possam promover a articulação entre estes, com o objetivo de valorizar e o aperfeiçoar os Conselhos de Direitos como instrumentos de efetivação da democracia direta.

\subsection{Articulação entre os Conselhos para a Proteção dos Direitos da Criança e do Adolescente}

Como vimos a Política de Proteção aos Direitos da Criança e do Adolescente, bem como as políticas sociais, seguem os ideais previstos na Constituição de 1988, no que diz respeito à participação da sociedade civil na gestão das políticas públicas. Para exercerem o controle social foram previstos, dentre outros, os Conselhos de Direitos.

Os Conselhos são canais importantes de participação coletiva, que possibilitam a criação de uma nova cultura política e novas relações políticas entre governos e cidadãos. São também uma das mais legítimas formas de democracia direta. ${ }^{47}$

Os Conselhos de Direitos são órgãos previstos no Sistema de Garantias previsto no Estatuto da Criança e do Adolescente. Portanto, exercem uma função estratégica perante a Política de Proteção dos Direitos da Criança e do Adolescente, porque integram o sistema descentralizado de gestão governamental, e contam com a participação da sociedade civil na formulação, execução e avaliação desta política. A função dos Conselhos não é meramente consultiva, mas sim deliberativa.

\footnotetext{
${ }^{46}$ Apud. VIVARTA, Veet (coord). Ouvindo Conselhos: democracia participativa e direitos da infância na pauta das redações brasileiras. São Paulo: Cortez, 2005.

$47 \mathrm{Na}$ democracia direta, os cidadãos jamais delegam o seu poder de decisão. As decisões são tomadas em assembléias gerais. Se por acaso precisam de um representante, este só recebe os poderes que a assembléia quiser darlhe, os quais podem ser revogados a qualquer momento. Assim, na democracia direta, o poder do representante se assemelha ao que é conferido por um mandato comercial.
} 
Em termos da tradição política brasileira, os Conselhos de Direitos são entidades inéditas, conseqüência de uma conquista da sociedade civil para imprimir níveis crescentes de democratização na esfera pública, uma vez que em nosso país há uma forte trajetória de centralização e concentração de poder.

A composição paritária dos Conselhos, com representação da Sociedade Civil e do Governo, caracteriza os conselhos como instâncias de negociação de conflitos entre diferentes grupos e interesses, sendo, portanto um campo de disputas políticas, de conceitos e processos, de significados e resultantes políticos. ${ }^{48}$

As propostas democratizadoras do Estado e das políticas públicas, bem como a criação dos Conselhos vieram na contramão do fortalecimento de ideologias contrárias à universalização dos direitos sociais, aprofundando a privatização do público. Para reforçar tal posicionamento vale mencionar a seguinte afirmação de Raichelis:

"Muitos dos desafios atuais relacionam-se ao contexto adverso em que os conselhos foram implantados - de esvaziamento das responsabilidades públicas do Estado, de desqualificação das instâncias de representação coletivas, de fragmentação do espaço público e de despolitização da política, processos que fragilizam a capacidade de a sociedade civil exercer pressão direta sobre os rumos da ação estatal. Outras dificuldades decorrem da própria lógica de estruturação das políticas públicas na sociedade capitalista e da natureza da intervenção estatal nesse campo." 49

Como conseqüência desta característica centralizadora e de privatização do público as Políticas Sociais foram fragmentadas e setorizadas, na tentativa de dissolvê-las e fragiliza-las, uma vez que são contrárias ao paradigma neoliberal capitalista.

A Política de Proteção aos Direitos da Criança e do Adolescente obedece à lógica da setorização, em que a política é tida como partes segmentadas, sem comunicação e articulação.

${ }^{48}$ RAICHELIS, Raquel, A Articulação entre os conselhos de políticas públicas: uma pauta a ser enfrentada pela sociedade civil. Diponível em: $<$ http//LwWw.abong.org.br/novosite/download/4 raquel.pdf.

${ }^{49}$ Ibidem. 
Como conseqüiência deste processo ocorrem dificuldades na ação pública dirigida à implementação de políticas redistributivas que tenham reflexo na garantia de direitos. ${ }^{50}$

Segundo Raichelis a fragmentação e a setorização interfere na efetividade das políticas públicas e seus impactos na melhoria das condições de vida da população. Reflete também nos Conselhos que foram criados no âmbito das políticas sociais públicas setoriais, cada um deles voltados para ações específicas no seu campo de intervenção. Neste sentido:

"A multiplicação acelerada dos conselhos, a dinâmica própria de funcionamento de cada um e o envolvimento com pautas específicas contribuem, mesmo que voluntariamente, para manter a fragmentação e a segmentação das políticas públicas, dificultando, em última instância, o enfrentamento da lógica que estrutura a ação estatal e a capacidade de produzir respostas satisfatórias em cada uma de suas áreas." 51

A fragmentação da Política de Proteção aos Direitos da Criança e do Adolescente também reflete em seu controle social. No Distrito Federal esta política é executada, basicamente, pela Secretaria de Ação Social e a Secretaria de Justiça e de Direitos Humanos, e não só a execução é setorizada, também o controle social mantém esta tendência de trabalho fragmentado, sem qualquer articulação. ${ }^{52}$

Neste sentido observa-se que apesar da implementação dos Conselhos terem avançado nos últimos anos ainda há uma série de limitações para seu progresso, segundo menciona a assistente social do Conselho de Assistência Social do Distrito Federal - CAS/DF durante a entrevista.

O primeiro é o ambiente jurídico ou normativo, que inclui as leis municipais e outras regulações, como regimento interno e manuais de procedimentos. O segundo é relativo à

\footnotetext{
${ }^{50}$ Ainda a questão social, expressão multifacetada de conflitos e problemas decorrentes das lutas pela apropriação da riqueza social, tende segundo Raichelis a ser restrita aos objetos de cada uma das políticas setoriais, "dificultando a formulação de análises e propostas de intervenção que considerem a realidade social como uma totalidade complexa, dinâmica, conflituosa".

${ }^{51}$ RAICHELIS, Raquel, A Articulação entre os conselhos de políticas públicas: uma pauta a ser enfrentada pela sociedade civil. Diponível em: <http//Www.abong.org.br/novosite/download/4_raquel.pdf.

${ }^{52}$ A Política de Proteção aos Direitos da Criança e do Adolescente é transversal e abrange outras áreas além da Assistência Social, como por exemplo, a Saúde. Mas neste trabalho versa apenas à área de Direitos Humanos e Assistência Social, por entender que estas políticas contêm maior impacto na proteção da criança e do adolescente.
} 
estrutura física humana: carro, telefone, internet, pessoal administrativo e técnico. Mais subjetivos, idade, instrução profissão, motivações à candidatura e a própria formação pessoal do conselheiro também, podem ser limitadoras ou potencializadoras. Em seguida vêm as demandas, as ações e as atribuições. Por último, as suas relações: como o conselho interage com a criança, o adolescente e a família, com a comunidade e a sociedade em geral, com as esferas de governo, com o Ministério Público e com a mídia. Segundo o André Kaminski "precisamos trabalhar todos esses ambientes potencialmente limitadores para poder avançar mais". ${ }^{53}$

É nesse contexto que se impõe a necessidade de discutir os mecanismos de articulação entre os Conselhos de Direitos visando reduzir e amenizar os aspectos limitadores na defesa dos direitos e das políticas sociais.

Conforme a Raichelis a articulação entre os diferentes Conselhos de Direitos é um desafio que deve ser enfrentado em razão da natureza transversal das várias políticas sociais, verbis:

"O enfrentamento desse desafio é ainda mais relevante se considerarmos a natureza transversal a várias políticas sociais de áreas como a da criança e do adolescente, sendo absolutamente insuficientes seu planejamento e sua gestão de forma isolada do conjunto das ações sociais públicas. Outras, como a assistência social, além do esforço para se constituir como política específica tem como vocação viabilizar a relação orgânica de um conjunto de políticas sociais, tensionando-as no sentido de incluir novos sujeitos demandantes de serviços e direitos, historicamente excluídos de seu alcance.

Mas para que essas possibilidades se concretizem, é fundamental que a perspectiva de interface entre as políticas sociais seja assumida pelos gestores governamentais nas três esferas de poder como uma prioridade de seus planos de ação. É preciso decisão política do Executivo para a criação de instâncias organizativas que viabilizem a gestão intersetorial democrática e participativa, de forma a dar suporte às ações integradas entre programas e projetos sociais a serem priorizados, incluindo necessariamente o planejamento e a alocação de recursos orçamentários para tal finalidade."

Verifica-se que os Conselhos de Direitos em ações pontuais contam com a articulação entre os diversos âmbitos da política social como um instrumento de gestão e de garantia de participação democrática, contudo é necessário pensar alternativas sistemáticas e contínuas de

\footnotetext{
53 Apud. Apud. VIVARTA, Veet (coord). Ouvindo Conselhos: democracia participativa e direitos da infância na pauta das redações brasileiras. São Paulo: Cortez, 2005.
} 
interação e para isto o fortalecimento da participação da sociedade civil nos Conselhos se mostra fundamental. Neste sentido:

"Mas para disputar criativamente o sentido e a direção das políticas sociais e democratizar a gestão pública, a articulação entre os conselhos, nas três esferas governamentais, é tarefa fundamental. E os desafios são grandes! Apesar de algumas iniciativas relevantes, é preciso viabilizar caminhos e alternativas que não sejam pontuais e esporádicos, mas que construam efetivamente uma agenda de articulação. Para isso, o papel das organizações e movimentos que compõem a representação da sociedade civil nos conselhos é crucial". 54

A atuação das diversas forças de poder que compõem a gestão e a formulação de políticas públicas para a criança e o adolescente deve ser direcionada para o fortalecimento de alianças entre entidades, organizações não-governamentais e movimentos sociais para que os conselhos possam transcender seus limites, "por vezes estreitos e corporativistas, de suas pautas específicas, avançando na identificação das interfaces e das possibilidades de constituição de agendas comuns". 55

Este esforço deve ser no sentido de promover a discussão da política de defesa da criança e do adolescente nos espaços coletivos, e criar canais e veículos de informação integrados pelos vários conselhos, e não reforçar a visão setorizada e fragmentada das políticas sociais.

Como visto os Conselhos de Direitos são órgãos que exercem uma função pública e como tal devem seguir os princípios da administração pública, dentre eles destaca-se o da publicidade, sendo fundamental para os conselhos se consolidarem como espaços públicos democráticos a visibilidade pública. De acordo com Raichelis a transparência e a informação entre os Conselhos precisam ser intensificadas, verbis:

"Isso significa que as ações, os discursos e os critérios que orientam as deliberações dos conselhos devem-se expressar com fidedignidade e publicidade, não apenas para os diretamente envolvidos, mas para todos os que serão implicados pelas decisões assumidas. Para isso, a transparência e a circulação das informações interconselhos precisam ser intensificadas, para que seu acesso seja

${ }^{54}$ RAICHELIS, Raquel, A Articulação entre os conselhos de políticas públicas: uma pauta a ser enfrentada pela sociedade civil. Diponível em: <http//WWW.abong.org.br/novosite/download/4 raquel.pdf.

${ }^{55}$ Ibidem. 
cada vez mais amplo e contribua para uma visão de totalidade da política social que está sendo implementada”. 56

Contudo, identifica Raichelis que há significativa unanimidade nos estudos e avaliações da experiência dos Conselhos quanto à frágil representação da sociedade civil. Assim, a luta pela ampliação de direitos sociais "está diretamente relacionada à ampliação de espaços públicos". 57

Verifica-se, portanto, que a dinâmica de funcionamento dos Conselhos deve ser repensada e reavaliada para que não se reflita na precariedade da participação da sociedade civil a exclusão destes novos atores sociais da esfera decisória das políticas sociais.

Outra questão relevante relaciona-se às demandas de capacitação dos conselheiros. De acordo com Raichelis é importante para a existência da articulação entre os diversos Conselhos de Direitos uma capacitação conjunta:

"Para a articulação dos conselhos, também é fundamental incluir nos projetos de capacitação dos conselheiros a demanda de formação conjunta dos vários conselhos, para que, sem diluir as questões específicas, possam desenvolver conteúdos voltados para temáticas gerais, que garantam a análise crítica sobre os mecanismos de formulação e gestão da coisa pública, bem como sobre o funcionamento dos diversos aparelhos e instâncias que compõem o Estado em seus vários níveis de poder. Ao mesmo tempo, o fortalecimento de atores coletivos poderia ser mais explorado por diferentes formatos de capacitação direcionados à criação de vínculos mais estreitos com outros atores coletivos, por intermédio de organizações e movimentos sociais nos quais se inserem, do que com atores individuais." 58

Sendo a intersetorialidade e de articulação entre as políticas sociais uma questão estratégica. Raichelis destaca ainda necessidade de criar 'instâncias responsáveis por relações

\footnotetext{
${ }^{56}$ RAICHELIS, Raquel, A Articulação entre os conselhos de políticas públicas: uma pauta a ser enfrentada pela sociedade civil. Diponível em: <http//Www.abong.org.br/novosite/download/4_raquel.pdf.

57 Ibidem.

${ }^{58}$ RAICHELIS, Raquel, A Articulação entre os conselhos de políticas públicas: uma pauta a ser enfrentada pela sociedade civil. Diponível em: <http//Www.abong.org.br/novosite/download/4 raquel.pdf.
} 
intersetoriais e interdisciplinares que garantam a integração entre setores e níveis decisórios, assim como o monitoramento e a avaliação dos resultados". 59

Conforme entrevistas realizadas no Conselho de Assistência Social do Distrito Federal - CAS/DF e no Conselho de Direitos da Criança e do Adolescente - CDCA/DF, verifica-se que não existem ações comuns, cada órgão exerce sua atividade independente do outro. Esta idéia é reforçada pelo fato da Política de Proteção aos Direitos da Criança e do Adolescente ser executada, basicamente, por dois órgãos distintos.

A fragmentação das políticas sociais conduziu a fragmentação do controle social, onde CDCA/DF atua no acompanhamento, fiscalização e controle da política executada pela Secretaria de Justiça e de Direitos Humanos, que prioriza a questão das crianças e adolescentes em conflito com a lei, abuso sexual de crianças e adolescentes ameaçadas de morte, enquanto o CAS/DF atua no acompanhamento, fiscalização e controle da política executada pela Secretaria de Ação Social, priorizando o atendimento sócio educativo, erradicação do trabalho infantil, geração e transferência de renda.

Contudo pode-se extrair da análise documental e da entrevista realizadas nos Conselhos que tanto o CDCA/DF e o CAS/DF atuam na fiscalização das entidades que prestam atendimento à criança e adolescente, como por exemplo, os abrigos. Mas mesmo exercendo atividades comuns estes Conselhos não mantêm qualquer relação, nem mesmo de troca de informação, o que reforça a fragmentação e a fragilidade das políticas.

Nesta articulação com os diversos órgãos responsáveis pelas políticas sociais os Conselhos de Direitos devem assumir a responsabilidade de promover o debate intersetorial entre as diferentes esferas de poder, podendo conforme expõe Raichelis "contar com assessoria externa para

\footnotetext{
${ }^{59}$ RAICHELIS, Raquel. A Articulação entre os conselhos de políticas públicas: uma pauta a ser enfrentada pela sociedade civil. Diponível em: 〈http//WwW.abong.org.br/novosite/download/4 raquel.pdf.y. Acesso em 14 mai.2007.
} 
propor ações em rede que diminuam o paralelismo e permitam ocupar os vazios de atendimento em múltiplos campos e temáticas". 60

Neste sentido vale citar ainda uma experiência interessante e importante para o fortalecimento do controle social como mecanismo de participação social, que é a Casa de Conselhos. Este é um projeto da Prefeitura Municipal de Araraquara/SP, que tem por objetivo fortalecer a participação popular para o exercício pleno do controle social, com participação popular e inclusão social. A Casa de Conselhos consiste em uma congregação dos órgãos colegiados do Município de Araraquara, em um espaço púbico, que acolhe os conselheiros para oferecer assessoria, capacitação, articulação e consulta sobre as atividades de todos os Conselhos Municipais. Dentre as várias ações executadas destaca-se a criação de um "Fórum Interconselhos" que seria a instância responsável pela articulação entre os vários Conselhos. ${ }^{61}$

No Distrito Federal com a posse do novo Governador em 2007, todos os Conselhos de Direitos, foram colocados no mesmo prédio, o que deveria facilitar o convívio e a interação entre estes órgãos. Porém, o que se pode perceber durante a entrevista realizada dos Conselhos é que cada órgão exerce sua atividade independente do outro.

Pode-se verificar pelo trabalho que os Conselhos ainda estão inseridos na racionalidade setorizada e fragmentada da Política de Proteção à Criança e ao Adolescente, proposta pelos ideais neoliberais. Contudo a responsabilidade pelo fortalecimento da Política de Proteção aos Direitos da Criança e do Adolescente no Distrito Federal é de responsabilidade do Conselho dos Direitos da Criança e do Adolescente do Distrito Federal - CDCA/DF e o Conselho de Assistência Social do Distrito Federal - CAS/DF, que devem promover o debate intersetorial construindo uma agenda conjunta, sistemática e contínua.

\footnotetext{
${ }^{60}$ Apud. VIVARTA, Veet (coord). Ouvindo Conselhos: democracia participativa e direitos da infância na pauta das redações brasileiras. São Paulo: Cortez, 2005.

${ }^{61}$ Esta informação foi retirada do site www.araraquara.sp.gov.br. Destaca-se ainda que esta iniciativa é observada em outros Municípios do estado de São Paulo como Campinas, Guarulhos e no estado do Paraná no Município de Irati.
} 


\section{CONSIDERAÇÕES FINAIS}

Este trabalho tratou da necessidade de articulação entre o Conselho de Assistência Social do Distrito Federal - CAS/DF e o Conselho dos Direitos da Criança e do Adolescente do Distrito Federal - CDCA/DF, para a proteção dos direitos da criança e do adolescente.

Como vimos a Política de Proteção aos Direitos da Criança e do Adolescente sempre esteve relacionada com a Política de Assistência Social, um exemplo é o fato do primeiro Código de Menores de 1927 ser a consolidação das leis de assistência voltadas para a infância. Podemos perceber também como ocorreu a evolução do tema infância e adolescência, que em um primeiro momento era caracterizado pela filantropia e a caridade, num segundo pela consolidação do sistema jurídico-adiminstrativo e no terceiro pelo reconhecimento da criança e do adolescente como sujeito de direitos.

A partir da instituição do Estado Democrático de Direito foram criados instrumentos de participação popular no processo decisório, dentre eles destaca-se os Conselhos de Direitos um dos executores do controle social, por serem órgãos integrantes do sistema descentralizado, cuja competência é formular, fiscalizar e avaliar as políticas públicas.

A institucionalização destes mecanismos de participação da sociedade civil na gestão pública surgiu em um momento caracterizado pela privatização do público, sob a égide dos ideais neoliberais, que acarretou a fragmentação das políticas sociais.

No Distrito Federal a Política de Proteção aos Direitos da Criança e do Adolescente seguem esta mesma lógica de fragmentação e setorização das políticas sociais, uma vez que a esta é executada pela Secretaria de Justiça e Direitos Humanos, quanto à questão do adolescente em conflito com a lei, abuso sexual de crianças e adolescentes, e crianças e adolescentes ameaçados de morte; e pela Secretaria de Ação Social quanto ao atendimento sócio educativo, erradicação do trabalho infantil, e a transferência de renda.

O Controle Social exercido pelo Conselho da Assistência Social - CAS/DF, e pelo Conselho dos Direitos da Criança e do Adolescente - CDCA/DF, tem ações comuns como, por exemplo, a fiscalização dos abrigos e de entidades que prestam atendimento sócio educativo às 
crianças e adolescentes. Entretanto seguem a mesma lógica da setorização, e não mantém qualquer interação, conforme entrevista realizada nos Conselhos.

Durante a entrevista pude perceber que o Conselho de Assistência Social do Distrito Federal - CAS/DF entende que a falta de comunicação é um limitador, porque muitas vezes há entidades de assistência social que são denunciadas por maus tratos ou tratamento inadequado às crianças perante o Conselho de Direitos da Criança e do Adolescente do Distrito Federal CDCA/DF que não chegam ao conhecimento do CAS/DF, o que dificulta a apuração dos fatos durante a fiscalização.

Quanto ao Conselho de Direitos da Criança e do Adolescente do Distrito Federal CDCA/DF esta não é uma preocupação marcante, pude verificar que este Conselho está mais preocupado em a questão da capacitação dos Conselheiros para a análise do orçamento e gerenciamento do Fundo da Criança e do Adolescente. Tendo a falta de capacitação também se apresentado como um limitador para o CAS/DF.

Logo podemos afirmar que os problemas enfrentados pelo Conselho de Assistência Social do Distrito Federal - CAS/DF são os mesmos enfrentados pelo Conselho de Direitos da Criança e do Adolescente do Distrito Federal - CDCA/DF, ou seja, recursos humanos e materiais, fragilidade na participação da sociedade civil, falta de capacitação dos conselheiros, necessidade de fortalecimento do órgão. Assim, percebemos a necessidade de articulação entre os Conselhos de Direitos a fim de amenizar e buscar soluções conjuntas para estes problemas.

Pode-se afirmar que os Conselhos de Direitos estão inseridos na racionalidade setorizada e fragmentada das Políticas Sociais. Contudo cabe ao Conselho dos Direitos da Criança e do Adolescente do Distrito Federal - CDCA/DF e ao Conselho de Assistência Social do Distrito Federal - CAS/DF, promover o debate intersetorial construindo uma agenda de ações conjuntas, sistemáticas e contínuas.

Assim hipótese da pesquisa de que o Conselho de Assistência Social do Distrito Federal - CAS/DF e o Conselho de Direitos da Criança e do Adolescente - CDCA/DF ainda não se 
articulam e isto fragiliza a Política de Proteção aos Direitos da Criança e do Adolescente foi confirmada.

Os objetivos específicos da pesquisa foram alcançados, pois foi possível compreender a Política de Proteção aos Direitos da Criança e do Adolescente, por meio de uma análise comparativa da legislação e do processo histórico da criança e do adolescente; entender como são executadas as ações de proteção à criança e ao adolescente atualmente, e em que lógica estão inseridas; analisar a natureza, composição e função dos Conselhos de Direitos; e buscar justificativa teórica política e teórica para a necessidade da articulação entre os Conselhos de Direitos no aperfeiçoamento do controle social.

Deste modo o objetivo geral da pesquisa foi cumprido na medida em que foi encontrada uma justificativa política e teórica para a necessidade de articulação entre os Conselhos de Direitos que acompanham, fiscalizam e controlam a Política de Proteção aos Direitos da Criança e do Adolescente visando o aperfeiçoamento dos mecanismos de controle social foi encontrada. 


\section{BIBLIOGRAFIA}

- ASSOCIAÇÃO BRASILEIRA DE NORMAS TÉCNICAS. NBR 6023: informação e documentação: referências - elaboração. Rio de Janeiro, 2000.

- CENTRO UNIVERSITÁRIO DE BRASÍLIA. Faculdade de Ciências Jurídicas e Sociais. Curso de Direito. Manual de Elaboração de Monografias. Brasília, 2002.

- DECRETO nº 17.943-A, de 12 de outubro de 1927. Dispõe sobre o Código de Menores

- DIDONET, Vital. Representação da Criança na Sociedade Brasileira. Infância e Desenvolvimento: Desafios e Propostas, Organizadores Antônio Rocha Magalhães e Walter Garcia, Brasília: IPEA, Série IPEA; n.140, 1993.

- DISTRITO FEDERAL. Resolução nº12, de 6 de agosto de 2002. Dispõe sobre o Regimento Interno do Conselho de Assistência Social do Distrito Federal - CAS/DF.

- FALEIROS. Vicente de Paulo. Uma Década de Direitos: Avaliação dos dez anos de Estatuto da Criança e do Adolescente. Série Escola de Conselhos. Cadernos para a Cidadania. Brasília: CECRIA, 2000.

- INSTITUTO INTERAMERICANO DEL NIÑO, Editora Universitária Santa Úrsula, AMAIS Livraria e Editora. A Arte de Governar Crianças: A História das Políticas Sociais, da Legislação e da Assistência à Infância no Brasil. Rio de Janeiro:1995.

- Internet

- LEI n ${ }^{o}$ 6.697, de 10 de outubro de 1979. Dispõe sobre o Código de Menores.

- MARTINS, Danielle Comim. Estatuto da Criança e do Adolescente e a Política de Atendimento. 1. ed. Curitiba: Juruá, 2004. 
- MERISSE, Antônio; JUSTO, José Sterza; ROCHA, Luiz Carlos et al. Lugares da Infância: reflexões sobre a história da criança na fábrica, creche e orfanato. São Paulo: Arte e Ciência, 1997.

- RAICHELIS, Raquel. A Articulação entre os conselhos de políticas públicas: uma pauta a ser enfrentada pela civil. Disponível em: $<$ http//wwW.abong.org.br/novosite/download/4 raquel.pdf.:. Acesso em 14 mai.2007.

- RAICHELIS, Raquel. Esfera Pública e Conselhos de Assistência Social: caminhos da construção democrática. São Paulo: Cortez, 1998.

- RIZZINI, Irene; RIZZINI, Irmã. A Institucionalização de Crianças no Brasil: percurso histórico e desafios do presente. Editora PUC, Rio de Janeiro: 2002.

- SILVA, José Afonso. Curso de Direito Constitucional Positivo. São Paulo: Malheiros, 2005.

- Site http://www.araraquara.sp.gov.br.

- Site'http://www.mds.gov.brh institucional/

- Site htttp://Wwww.presidencia.gov.br/estrutura presidencia/sedh/,

- VIEIRA, L.M.F. Mal Necessário: Creches no Departamento Nacional da Criança. Caderno de Pesquisa, n.67, p. 3-16, nov. 1988.

- VIVARTA, Veet (coord). Ouvindo Conselhos: democracia participativa e direitos da infância na pauta das redações brasileiras. São Paulo: Cortez, 2005. 


\section{ANEXO \\ ROTEIRO DE ENTREVISTA}

\section{Bloco I - Questões sobre a Instituição}

1) Quando o Conselho foi criado?

2) Houve diferença entre a data de criação e o início de suas atividades?

3) Há Regimento Interno?

4) O Conselho tem orçamento próprio?

5) O Conselho segue o que dispõe os Conselhos Nacionais (CONANDA/CNAS)?

\section{Bloco II - Questões sobre a competência da Instituição}

1) O Conselho tem competência para formular a Política de Proteção aos Direitos da Criança e do Adolescente e/ou de Assistência Social. Qual é a Política de proteção local?

2) Os Conselhos tem como competência promover, apoiar e incentivar a realização de estudos e pesquisa na área da Política. Esta atribuição é realizada? Como?

3) O Conselho a cada dois anos deve convocar a Conferência Distrital para avaliar a Política. Qual o nível de participação das entidades e da sociedade civil nesta Conferência?

4) Quais as limitações para a execução de tais competências (Recursos humanos, materiais, físicos)?

5) Os Conselheiros estão capacitados para deliberar sobre a Política?

\section{Bloco III - Questões sobre o Orçamento}

1) Ainda quanto às competências o Conselho deve assessorar o Poder Executivo na elaboração da proposta orçamentária. O Conselho tem caráter deliberativo no caso do orçamento?

2) Os Conselheiros são competentes para deliberar sobre o orçamento?

3) Para financiar a Política utiliza exclusivamente os recursos do Fundo de Assistência Social e/ou Fundo dos Direitos da Criança e do Adolescente?

4) Os recursos deste fundo são suficientes para financiar a Política? 
This document was created with Win2PDF available at http://www.win2pdf.com.

The unregistered version of Win2PDF is for evaluation or non-commercial use only.

This page will not be added after purchasing Win2PDF. 